\title{
ANÁLISE MICROSCÓPICA DE REBORDOS ALVEOLARES MAXILARES RECONSTRUÍDOS COM ENXERTOS AUTÓGENOS DE CRISTA ILÍACA E REGIÃO MENTONIANA
}

\section{MARIZA AKEMI MATSUMOTO}

Dissertação apresentada à Faculdade de Odontologia de Bauru da Universidade de São Paulo, como parte dos requisitos para obtenção do grau de Mestre em Odontologia, área de Patologia Bucal.

\section{BAURU}




\section{ANÁLISE MICROSCÓPICA DE REBORDOS ALVEOLARES MAXILARES RECONSTRUÍDOS COM ENXERTOS AUTÓGENOS DE CRISTA ILÍACA E REGIÃO MENTONIANA}

\section{MARIZA AKEMI MATSUMOTO}

Dissertação apresentada à Faculdade de Odontologia de Bauru da Universidade de São Paulo, como parte dos requisitos para obtenção do grau de Mestre em Odontologia, área de Patologia Bucal.

Orientador: Prof. Dr. Alberto Consolaro

\section{BAURU}




\section{Ficha Técnica}

Mariza Akemi Matsumoto: concepção original, experimento, redação e digitação Alberto Consolaro: concepção original, orientação geral, ilustração, redação, revisão final Juracy do Nascimento: histotécnica

Maria Izalina Ferreira Alves: estatística

Modesto Dian Júnior: formatação

Valdir João Afonso: revisão final e vernáculo

Valéria Cristina Trindade Ferraz: normatização técnica

Marcus Thame: cópias e encadernação

\section{Matsumoto, Mariza Akemi}

M429a Análise microscópica de rebordos alveolares maxilares reconstruídos com enxertos autógenos de crista ilíaca e região mentoniana. / Mariza Akemi MatsumotoBauru, 1999.

143 p.:il.; $28 \mathrm{~cm}$.

Dissertação. (Mestrado) - Faculdade de Odontologia de Bauru. USP.

Orientador: Prof. Dr. Alberto Consolaro

Autorizo, exclusivamente para fins acadêmicos e científicos, a reprodução total ou parcial desta dissertação / tese, por processos fotocopiadores e / ou meios eletrônicos.

Assinatura do autor:

Data: Bauru, 13 de outubro de 1999 


\section{DADOS CURRICULARES}

\section{Mariza Akemi Matsumoto}

18 de fevereiro de 1969

Bauru - SP

Filiação

1991-1995

1996

1998-1999

Associações
Nascimento

Kunio Matsumoto

Victoria Oshiro Matsumoto

Curso de Graduação em Odontologia pela Universidade do Sagrado Coração de Bauru - SP

Professora Auxiliar das Disciplinas de Cirurgia e Traumatologia Bucomaxilofacial do Curso de Odontologia da Universidade do Sagrado Coração de Bauru - SP

Mestrado em Patologia Bucal pela Faculdade de Odontologia de Bauru - SP

Sociedade Brasileira de Ensino e Pesquisa Odontológica 


\section{A DEUS,}

$$
\text { pelas graças concedidas a cada dia, }
$$

Aos meus queridos pais, Kunio e Victória, à Eliana, Valério e ao pequeno João Victor, por sua bondade, desprendimento e infindáveis demonstrações de amor e respeito, dedico este trabalho. 
Nenhuma história humana é escrita sem a presença de uma ou duas mãos amigas que se estendem em nossa direção. 


\section{AgradeÇo}

Ao Professor Dr. Alberto Consolaro,

por compartilhar seus ensinamentos, pela inigualável

dedicação e amor à profissão e ao desenvolvimento científico e orientação deste trabalho. 


\section{Ao Professor Dr. Hugo Nary Filho,}

exemplo de honestidade e competência, pela extrema

dedicação e carinho na colaboração deste trabalho e na minha vida profissional. 
Aos estimados Professores da Disciplina de Cirurgia e Traumatologia Bucomaxilofacial da Universidade do Sagrado Coração de Bauru, Hugo Nary Filho, Aparício Fiuza de Carvalho Dekon, Roberto Yoshio Kawakami e Luís Eduardo Marques Padovan, exemplos de dedicação e lealdade, verdadeiros responsáveis pelos caminhos que hoje percorro, pelo incentivo e amizade constantes;

Aos meus queridos amigos Paulo Domingos Ribeiro Júnior, Eduardo Sanches Gonçales e Ricardo Falcão Tuler, pelas inúmeras demonstrações de carinho e compreensão, os quais tornaram possível a realização deste trabalho;

Aos Professores do Departamento de Patologia da Faculdade de Odontologia de Bauru, Universidade de São Paulo, Dr. Alberto Consolaro, Dr. Luís Antônio de Assis Taveira, Dra. Denise Tostes Oliveira e Dra. Vanessa Soares Lara, pela contribuição na minha formação profissional;

À Irmã Marizabel Leite, pela imensa demonstração de respeito e confiança;

Aos Professores Dr. Luís Casati Alvares, Dr. Carlos Eduardo Francischone e Dra. Cláudia Piccino de Almeida Prado Sgavioli, responsáveis pelo meu amadurecimento e crescimento profissional; 
Aos Professores Gérson Francisco de Assis e Jesus Carlos Andreo, por suas contribuições e generosidade na elaboração deste trabalho;

Aos Funcionários do Departamento de Patologia da Faculdade de Odontologia de Bauru, Universidade de São Paulo, Sr. Valdir, Fatiminha, Cristina e Bernadete, pelos momentos e emoções compartilhados, e pelo incentivo e apoio;

Ao Juracy do Nascimento, pela valiosa contribuição e competência profissional;

À querida amiga Fernandinha, pela amizade sincera e constante;

Aos companheiros do Curso de Mestrado, Regina, Marianne, Mônica, Maria Renata, Márcia e Doutorado, Liliana, Mírian, Cássio, Francisco, Simone, Nilce, Washington, Renatinha e Nádia, pelos momentos compartilhados;

Aos estagiários da Disciplina de Cirurgia e Traumatologia Bucomaxilofacial da Universidade do Sagrado Coração de Bauru, Aline, Luís César, Victor e Éric, pela dedicação e colaboração nunca negadas; 
Aos administradores, médicos e funcionários da Associação Hospitalar de Agudos e Hospital Santa Casa de Misericórdia de Jaú, pelo convívio e oportunidade de desenvolvimento profissional;

Aos caros Dr. Agnaldo Elon Dizars e Dr. Milton Cury Filho, pela amizade e competência na condução dos casos apresentados neste trabalho;

Ao querido Dr. Onassis Leme Silva, por seu desprendimento e dedicação, a quem entregamos a responsabilidade dos procedimentos anestésicos;

Ao Modesto Dian Júnior, pela valiosa contribuição e primor na formatação deste trabalho;

Aos Funcionários do Setor de Odontologia da Universidade do Sagrado Coração de Bauru, pelas inúmeras demonstrações de dedicação e empenho;

Aos funcionários da biblioteca e do setor de pósgraduação da Faculdade de Odontologia de Bauru-USP, pela disponibilidade e atenção nunca negadas;

A todos que indiretamente contribuíram no desenvolvimento deste trabalho; 
Meus sinceros agradecimentos!

\section{Agradecimentos Institucionais}

À Direção da Universidade do Sagrado Coração de Bauru, na pessoa da Magnífica Reitora, Ir. JACINTA TUROLO GARCIA;

À Direção da Faculdade de Odontologia de Bauru, Universidade de São Paulo, na pessoa do Diretor, Professor Doutor AYMAR PAVARINI;

À Comissão de Pós-Graduação da Faculdade de Odontologia de Bauru, na pessoa do Presidente, Professor Doutor LUIZ FERNANDO PEGORARO. 


\section{SUMÁRIO}

\section{LISTA DE FIGURAS}

LISTA DE TABELAS

RESUMO

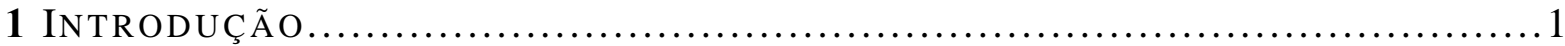

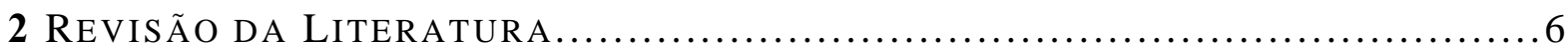

2.1 Implantes Osseointegrados em Enxertos Ósseos Autógenos....................6

2.2 Reparo dos Enxertos Ósseos Autógenos não Vascularizados..................22

2.3 Origem dos Enxertos Ósseos............................................... 30

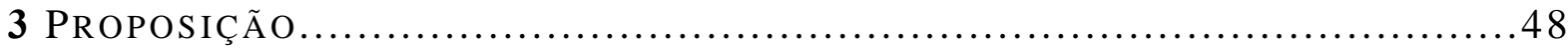

4 Material e Métodos....................................................... 49

4.1 Procedimentos Cirúrgicos e Obtenção das Amostras...........................49

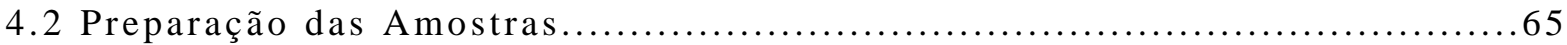

4.3 Análise Microscópica Descritiva........................................68

4.4 Análise dos Traçados das Áreas de

Matriz Óssea Mineralizada.....................................................69

4.5 Observações Clínicas................................................... 71

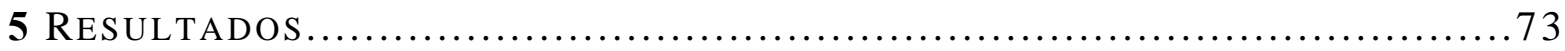

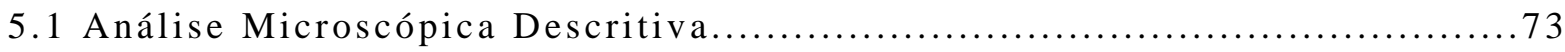

5.1.1 Espécimes Referentes às Biópsias Realizadas em Região de Enxerto de Crista Ilíaca...................................73

5.1.2 Espécimes Referentes às Biópsias Realizadas em Região de Enxerto de Mento...

5.2 Análise dos Traçados das Áreas de

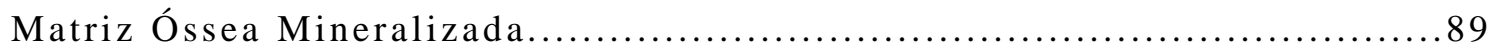

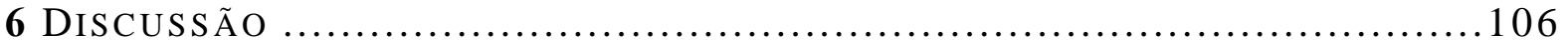

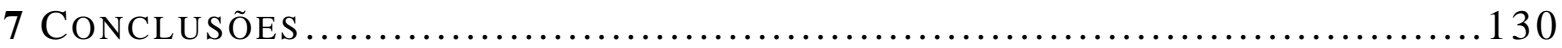


AnexOS

REFERENCIAS BIBLIOGRÁFICAS

ABSTRACT

\section{LISTA DE FIGURAS}

Figura 1 - Aspecto clínico da região de rebordo maxilar a ser reconstruida com enxerto de mento.

Figura 2 - Exposição do leito cirúrgico para visualização do defeito ósseo a ser reconstruído.

Figura 3 - A) Incisão na região de mucosa labial; B) Divulsão por planos; C) Exposição da região mentoniana.

Figura 4 - A) Osteotomia demarcando a região óssea a ser removida; B) Enxerto removido; C) Cavidade resultante da remoção do enxerto.

Figura 5 - Sutura da região doadora.

Figura 6 - Fixação do enxerto com parafusos de titânio.

Figura 7 - A) Aspecto clínico da região de rebordo maxilar a ser reconstruida com enxerto de crista ilíaca; B) Imagem tomográfica desta mesma região demonstrando a deficiência óssea em altura, pela extensão alveolar do seio maxilar, e espessura.

Figura 8 - Exposição do leito cirúrgico para visualização do defeito a ser reconstruído.

Figura 9 - A) Incisão de pele paralela à crista ilíaca com $8 \mathrm{~cm}$ de extensão; B) Descolamento e exposição da crista do ileo.

Figura 10 - A) Osteotomia com serra pneumática para remoção do bloco ósseo; B - C) Fragmento ósseo obtido de espessura bicortical. 
Figura 11 - A) Sutura da região doadora e instalação do dreno; B-C) Adaptação e fixação dos blocos de enxerto de crista ilíaca com parafusos de titânio.

Figura 12 - Método de obtenção da amostra, empregando broca trefina sobre o rebordo no período de quatro meses após a realização do enxerto.

Figura 13 - Aspecto macroscópico do espécime obtido.

Figura 14 - Exemplo de traçado.

Figura 15 - Distribuição dos eventos microscópicos característicos observados nos grupos de enxertos de crista ilíaca e mento, referentes às porções cortical e esponjosa.

Figura 16 - Enxerto ósseo de crista ilíaca no qual se observam, na porção esponjosa do enxerto, delgadas trabéculas ósseas (tb). Notam-se áreas originais sendo reabsorvidas (setas) e áreas de neoformação osteogênica associadas (setas menores) à superfície do osso original (oo) e aos novos espaços medulares, estabelecendo um novo trabeculado (tb). (Coloração H.E.; aumento original: $A=16 x ; B, C$ e $D=40 x$ ).

Figura 17 - Aspectos microscópicos do reparo e incorporação do enxerto ósseo de crista ilíaca na área receptora. Observam-se áreas de formação de tecido osteóide primário, ricamente celularizado (setas pequenas) e aleatoriamente depositado, como revelam as linhas incrementais irregulares (setas maiores). Gradativamente, no tecido ósseo neoformado, ocorre reorganização da medula óssea (mo). (Coloração H.E.; aumento original: $A, B, C$ e D $=40 x)$.

Figura18- Áreas de medula óssea fibrosa também são visualizadas. Observam-se novas trabéculas sendo formadas ora de osso primário (op) ricamente celularizado e desorganizado, ora com osso mais maduro (*) em $\mathbf{A}$ e B. Nas fotos $\mathbf{C}$ e $\mathbf{D}$, observa-se que o mesmo processo de renovação também ocorre nas corticais (setas). $\mathrm{Na}$ coloração de Tricrômico de Mallory, as áreas antigas de osso original (oo) ficam mais destacadas. (Coloração Tricrômico de Mallory; 
aumento original: A, B e D = 40x, coloração H.E.; aumento original: $\mathrm{C}=40 \mathrm{x})$.

Figura 19 - Aspectos microscópicos do reparo e incorporação do enxerto ósseo do mento. As trabéculas são mais espessas e associadas a novas trabéculas já estabelecidas pela osteogênese induzida e caracterizadas por áreas de osso primário (setas). Em D, pode-se observar que as trabéculas ósseas maduras estão em franca renovação e reorganização, denotadas pelas linhas incrementais (li). A osteogênese é destacada pela bem organizada camada de células osteoblásticas superficiais (ob). (Coloração H.E.; aumento original: $A=16 x ; B, C$ e $D=40 x)$.

Figura 20 - A coloração tricrômica destaca as áreas ósseas mais mineralizadas e organizadas, originariamente advindas do enxerto ósseo da área do mento (oo). Observa-se, também, o osso decorrente da osteogênese no contexto do reparo e da incorporação (ost). (Coloração Tricrômico de Mallory; aumento original: $\mathrm{A}$ e $\mathrm{B}=40 \mathrm{x})$.

Figura 21-Aspectos microscópicos denotando a presença de tecido adiposo preenchendo os espaços medulares. Intensa atividade de renovação óssea e osteogênese em função da riqueza e aleatoriedade das linhas incrementais (li) e da relação das trabéculas com a medula óssea (mo) em enxertos ósseos mentonianos. (Coloração H.E.; aumento original: $\mathrm{A}=16 \mathrm{x}$; $\mathrm{B}$ e $\mathrm{C}=$ $40 \mathrm{x})$.

Figura 22 - Análise gráfica dos resíduos dos dados da variável área óssea total das regiões.

Figura 23 - Diagrama de ramos e folhas dos dados da variável área óssea total das regiões.

Figura 24 - Médias da área óssea total devidas a cada tipo de enxerto estudado.

Figura 25 - Médias originais da área óssea total devidas a cada região de análise estudada. 
Figura 26 - Médias originais da área óssea total devidas a cada tipo de enxerto, dentro de cada região de análise estudada.

\section{LISTA DE TABELAS}

Tabela 1 - Caracterização da amostra.

Tabela 2 - Números resultantes das medidas dos traçados das superfícies ósseas das regiões A, B e C, obtidas dos enxertos de mento e crista ilíaca.

Tabela 3 - Análise da variância eteste $F$ para a variável área óssea total, em função dos fatores (causas da variação) tipos de enxertos, regiões e sua interação.

Tabela 4 - Médias da área óssea total devidas a cada tipo de enxerto estudado, e comparação pelo teste de Tukey.

Tabela 5 - Médias da área óssea total devidas a cada tipo de enxerto estudado.

Tabela 6 - Médias da área óssea total devidas a cada tipo de enxerto, dentro de cada região de análise estudada.

Tabela 7 - Períodos de espera para incorporação dos enxertos ósseos autógenos preconizados por diferentes autores para a instalação dos implantes osseointegrados. 


\section{RESUMO}

A instalação de implantes osseointegrados em rebordos atróficos reconstruídos com a utilização de enxertos ósseos autógenos vem sendo amplamente utilizada, principalmente com a adoção de dois tempos cirúrgicos. Neste estudo, buscou-se, à luz da microscopia óptica, avaliar o reparo e a qualidade óssea obtidos em rebordos maxilares que receberam enxertos de duas zonas doadoras, a crista ilíaca e o mento. Para tanto, dez pacientes submetidos à este tipo de reconstrução integraram a amostra. No período de quatro meses após este procedimento cirúrgico, no momento da colocação dos implantes, foram obtidos cinco espécimes de cada tipo de enxerto, por meio de biópsias realizadas com brocas trefinas. As peças cirúrgicas passaram por procedimento histotécnico de rotina e foram coradas pelas técnicas de H.E. e Tricrômico de Mallory. Como resultados, verificou-se tecido ósseo em franco processo de remodelação, evidenciado pelas numerosas áreas de osteogênese presentes em ambos os enxertos. Da análise das superfícies de matriz óssea 
mineralizada obteviveram-se valores significativamente maiores para as regiões que receberam enxerto de mento. Desta forma, concluiu-se que o período de quatro meses se mostrou suficiente para a incorporação dos enxertos, sendo viável a instalação dos implantes neste momento. Quanto à qualidade óssea, os enxertos de mento apresentaram-se superiores aos de ilíaco, possivelmente devido à sua arquitetura original. 


\section{INTRODUÇÃO}

Os implantes osseointegrados vêm se tornando cada vez mais um método alternativo viável às próteses convencionais para pacientes desdentados totais ou parciais.

O sucesso deste tratamento está diretamente relacionado à qualidade e quantidade óssea presentes nas regiões de implantação ${ }^{21,34,90}$. A partir da extração dentária, inicia-se um processo de perda óssea alveolar contínuo e progressivo ${ }^{28}$, podendo estar, ainda, acompanhado de outros agravantes, como a pneumatização do seio maxilar, acarretando deficiências ósseas em altura e espessura, as quais restringem ou mesmo impossibilitam, a colocação de implantes osseointegrados. A demanda para este tipo de tratamento vem aumentando, forçando o desenvolvimento de técnicas para reconstrução e adequação de rebordos alveolares atróficos 18,36,59,60,82.

Dentre os materiais utilizados nestas reconstruções, destacam-se os implantes aloplásticos, como a hidroxiapatita; os aloenxertos, com o uso de osso humano congelado desidratado e desmineralizado, os xenoenxertos e os autoenxertos $13,51,53,57,68,90$. 
Os autoenxertos, ou enxertos autógenos, apresentam vantagens sobre os demais pela ausência de imunogenicidade e pela presença de células ósseas viáveis com capacidade osteogênica, mesmo na ausência de células mesenquimais indiferenciadas ${ }^{75}$. Por estas razões, são largamente empregados nas mais variadas técnicas de reconstrução de rebordos, sendo inúmeras as opções de áreas doadoras.

A região da crista do ílio, ramo e mento na mandíbula e túber maxilar são zonas doadoras muito citadas para esta finalidade $1,10,13,26,31,33,36,46,55,56,87,88$. Já os enxertos removidos de costela, tíbia e calvária são referenciados com menor freqüência, apesar de apresentarem bons resultados clínicos $6,18,42,87,88$.

BREINE; BRANEMARK ${ }^{10}$, em 1980, foram os primeiros a avaliar o uso de enxertos ósseos autógenos e implantes para reconstrução de rebordos atróficos. A partir deste trabalho, diferentes técnicas de reconstrução têm sido utilizadas na reabilitação de pacientes parcial ou totalmente desdentados que apresentam deficiência ou ausência de osso alveolar. De um modo geral, pode-se agrupar estas técnicas nos seguintes procedimentos: técnicas de reconstrução com enxerto tipo onlay, baseada na fixação de grandes blocos ósseos sobre a crista do 
rebordo alveolar; técnica de reconstrução tipo veneer, onde o enxerto é posicionado sobre a face vestibular ou lingual, envolvendo ou não a crista para a obtenção de aumentos em altura e espessura; técnica inlay, onde o enxerto é posicionado no interior de defeitos ósseos, normalmente associada a osteotomias completas maxilares ${ }^{87,88}$, procedimentos de levantamento de seio maxilar ou fossa nasal36,59.

Quando se emprega autoenxertos, existe a possibilidade de colocação simultânea dos implantes ou a opção por dois tempos cirúrgicos distintos, um de reconstrução e outro de colocação das fixações ${ }^{1,10,60,71}$. Há uma tendência para realização de dois tempos cirúrgicos principalmente quanto maior for a extensão do defeito a ser reconstruído. Aparentemente, tais procedimentos oferecem prognóstico mais favoráve140,46,59,73,77.

Os relatos deste tipo de tratamento divergem quanto ao tempo de espera para a inserção dos implantes. O período mínimo encontrado foi de três meses ${ }^{94}$, mas, da mesma forma, citação de período de 18 meses foi verificada ${ }^{40}$.

$\mathrm{Na}$ realidade, pouco se sabe sobre as condições ósseas reais presentes na região enxertada nestes periodos sugeridos, 
acarretando em falta de consenso entre os pesquisadores. Estudo realizado em metacarpos e metatarsos de cavalos que receberam enxerto ósseo preenchendo defeitos previamente confeccionados, demonstraram que após o período de quatro meses tais defeitos estavam completamente preenchidos por novo tecido ósseo, firmemente aderido à superfície do osso enxertado ${ }^{75}$. Trabalhos em outros modelos experimentais podem não reproduzir os fenômenos biológicos que ocorrem em situações clínicas. Neste caso específico, as condições locais são totalmente diferentes, a arquitetura óssea receptora é distinta daquela verificada em ossos longos onde a maioria destes estudos foi conduzida.

Existe, ainda, discussão quanto à origem e natureza das regiões doadoras e receptoras dos enxertos. Sugere-se que a crista ilíaca, área doadora mais comumente utilizada nas reconstruções alveolares, apresenta maior indice de reabsorção pós-operatória que a verificada em enxertos empregando ossos de origem intramembranosa $6,26,53$.

Com base nestas divergências literárias, urge a necessidade de se conhecer as condições ósseas nas regiões reconstruídas, possibilitando indicar o momento mais adequado para praticar a colocação dos implantes. Duas questões emergem neste contexto: 
1) sabendo-se que a maioria dos relatos indica período de aguardo de quatro meses após o enxerto para a colocação das fixações, estaria esta região apta a receber os implantes neste período?

2) existe alguma diferença entre os enxertos obtidos da região de crista ilíaca e da mandíbula quanto à sua integração no leito receptor e quanto à qualidade óssea proporcionada pela reconstrução?

Com o intuito de oferecer mais informações para tais questões, idealizou-se o presente estudo, o qual procurará caracterizar à luz da microscopia óptica, as regiões de rebordo alveolar maxilar reconstruídas com enxertos ósseos obtidos do ílio e da mandíbula em pacientes submetidos a procedimentos de reabilitação com implantes osseointegrados realizados em dois tempos cirúrgicos. 


\section{REVISÃO DA LITERATURA}

O presente capítulo será dividido em três temas: implantes osseointegrados em enxertos ósseos, reparação dos enxertos ósseos não vascularizados e origem dos enxertos ósseos. A forma escolhida de apresentação deste capitulo caracteriza uma coletânea de resumos e trabalhos selecionados por assunto, tipificando uma revista de literatura.

\subsection{Implantes osseointegrados colocados em reconstruídos com enxertos ósseos autógenos}

O fenômeno da osseointegração requer a formação e remodelação constante de um tecido ósseo viável por sobre um material sintético, permitindo assim, sua estabilidade (BRANEMARK et al. ${ }^{1}$ 1995) .

Para isto, há necessidade de que a maior parte da superfície do implante esteja em contato com o tecido ósseo presente, condição nem sempre possível de ser conseguida nos pacientes à espera de reabilitação com implantes osseointegrados (ENGQUIST et al.19, 1988; FRIBERG; TORSTEN: LEKHOLM ${ }^{24}$, 
1991; JAFFIN; BERMAN ${ }^{34}$, 1991). Ossos densos aumentam a superfície de contato entre osso e implante, fornecendo maior estabilidade inicial ao implante durante o período de cicatrização após a cirurgia (SCHENK et al.74, 1994; TRUHLAR90, 1997). Desta maneira, recorre-se às técnicas de reconstrução alveolar já mencionadas, onde os enxertos ósseos autógenos ocupam lugar de destaque por suas qualidades inerentes (CITARDI, et al.13, 1994; SCHENK et al. $\left.{ }^{74}, 1994\right)$.

MARX; GARG50, em estudo realizado em 1998, sobre a influência do metabolismo, estrutura e fisiologia do tecido ósseo na implantodontia, constataram a sólida integração dos enxertos ósseos recomendando-os em casos de deficiência óssea alveolar com resultados mais satisfatórios quando comparados com ossos irradiados e até mesmo ossos normais, dependendo de sua qualidade.

BREINE; BRANEMARK ${ }^{10}$, no ano de 1980, foram os primeiros a avaliar o uso de enxertos ósseos e implantes osseointegrados para a reconstrução de maxilas atróficas, utilizando dois procedimentos distintos. Em um deles, os implantes eram instalados em combinação com os enxertos de tíbia; no outro, esperava-se que os implantes osseointegrassem 
na própria zona doadora para que, em um segundo tempo, fossem transportados para a maxila. No primeiro procedimento, apenas $25 \%$ dos implantes permaneceram osseointegrados; no segundo, um indice de $60 \%$ foi alcançado, mas com uma perda de $50 \%$ do volume ósseo. Desde então, diversos trabalhos experimentais e diferentes técnicas têm sido desenvolvidos objetivando a reabilitação de maxilas e mandỉbulas atróficas.

A fim de analisarem as reações biológicas do tecido ósseo enxertado na presença de implantes osseointegrados, PIATTELLI et al.65, em 1997, examinaram microscopicamente um implante removido de enxerto ósseo mandibular não vascularizado após período de dez meses de carga protética, proveniente de paciente de 63 anos de idade, onde, microscopicamente, pôde-se observar osso compacto maduro viável em íntimo contato com a superfície do implante. Não visualizaram descontinuidades ou presença de tecido conjuntivo fibroso. O osso enxertado apresentava características de estrutura e maturação diferentes do osso regenerado, com menor afinidade aos corante utilizados, mas apresentando uma linha fortemente corada pela fucsina básica, similar às linhas incrementais, as quais dividiam o osso enxertado do osso regenerado. Não se notou a presença de tecido ósseo não viável. As características do osso reparado e da 
interface osso-implante foram semelhantes às encontradas em ossos não enxertados, indicando a ocorrência de remodelação óssea local.

A remodelação óssea representa particular importância na manutenção da estabilidade a longo prazo dos implantes osseointegrados, cujo objetivo é o de transformar o tecido ósseo neoformado em uma estrutura de suporte mecanicamente competente. Durante esta fase, o osso primário sofre reabsorção e deposição seqüenciais para formar o osso lamelar, conferindo uma melhor resistência aos estresses locais (DAVIES ${ }^{15}$, 1998; MASUDA et al.52, 1998; $\operatorname{SCHENK}^{75}, 1994$; YASZEMSKI et al97, 1996).

DAVIES ${ }^{15}$, em 1998, ressaltou a importância da remodelação óssea na porção transcortical do implante, pois, a neoformação óssea acontece em locais específicos, onde os ósteons estão sofrendo remodelação; as outras porções, ficam ocupadas por osso antigo e não viável, ou por tecido conjuntivo resultante da lise do tecido ósseo.

Segundo resultados de $\mathrm{MARX}^{49}$ apresentados em trabalho publicado no ano de 1994, estudando a aplicação da biologia 
óssea às reconstruções maxilomandibulares, afirmou que, comparando a resistência à tração de implantes osseointegrados colocados em enxertos ósseos, tecido ósseo natural e irradiado, os melhores resultados foram alcançados nos implantes localizados nos enxertos ósseos, seguido pelo osso natural, e por último, o irradiado.

Tendo acesso aos parâmetros histomorfométricos da dinâmica óssea, GARETTO et al.25, em 1995, compararam a cinética do osso presente na interface com os implantes entre múltiplas espécies. Para tal, utilizaram 23 implantes adquiridos de experimentos em cães, coelhos e macacos, e também de humanos. Em intervalos de 1 a 2 semanas, antes da remoção dos implantes, eram administrados aos humanos e animais pelo menos dois marcadores ósseos. Para a comparação histomorfométrica, o osso circunjacente aos implantes foi dividido em duas regiões. O osso limite de $1 \mathrm{~mm}$ do implante foi classificado como adjacente; distâncias maiores que $1 \mathrm{~mm}$ e menores que $3 \mathrm{~mm}$ foram classificadas como distantes. Como resultado verificou-se que, em todas as amostras, a quantidade de osso em contato direto com os implantes variou de $14 \%$ a $75 \%$. Sem considerar a geometria do implante, a quantidade de osso em contato variou entre $35,4 \pm 6.9 \%$ e $62,8 \pm 10,8 \%$ em todas as 
espécies. Enquanto a maior porcentagem era de osso lamelar, significativamente mais osso primário foi mensurado nas regiões adjacentes aos implantes. Em amostras de humanos e cães, pouco osso primário foi notado em regiões distantes; grande quantidade deste osso foi encontrada em regiões adjacentes e distantes nos grupos dos coelhos e macacos. Em todas as espécies, o osso adjacente apresentou um grau muito maior de marcadores fluorocromo em comparação com o osso distante. Estes resultados indicaram o envolvimento de um aumento constante da remodelação óssea na região circunjacente ao implante relacionado ao sucesso da manutenção a longo prazo dos implantes osseointegrados.

Ainda no ano de 1995, JEMT; LEKHOLM ${ }^{35}$ compararam quatro tipos de tratamentos realizados para reabilitação de maxilas edêntulas com implantes osseointegrados após período de cinco anos de seguimento, levando-se em consideração a morfologia da maxila em conjunto com várias soluções protéticas. Os grupos incluíam: 1) utilização de enxerto ósseo, 2) reabsorção severa, 3) reabsorção intermediária e 4) reabilitação com prótese fixa. Dentre os indivíduos que receberam enxertos ósseos, 14 receberam próteses fixas e duas próteses removiveis. Os pacientes que apresentavam reabsorções severas da maxila 
tiveram o máximo possível de implantes colocados, assim, também, com relação ao comprimento, sendo reabilitados com overdentures. Aqueles que apresentavam reabsorção intermediária, foram reabilitados com próteses fixas após um ano de uso de overdentures. Receberam próteses fixas aqueles indivíduos que apresentavam quantidade óssea suficiente após a cirurgia de segunda fase. Observou-se que a maioria das perdas dos implantes ocorreu durante os primeiros anos em todos os grupos, com exceção do grupo dos enxertos ósseos. O maior indice de perda foi encontrado no grupo de reabsorção severa, cerca de $28,7 \%$, sendo o menor encontrado no grupo das próteses fixas, 7,6\%. Os grupos intermediários e dos enxertos ósseos mostraram perda de $20 \%$ dos implantes durante o período de observação. Estes resultados atentaram para a importância da avaliação pré-operatória da morfologia original e qualidade óssea para se poder selecionar a melhor alternativa protética, e ainda, a técnica cirúrgica mais adequada.

Com o objetivo de avaliar resultados a longo prazo de implantes osseointegrados colocados em enxertos ósseos autógenos de rebordos alveolares severamente atróficos, SCHLIEPHAKE; NEUKAM; WICHMANN76, em 1997, analisaram um total de 786 implantes colocados em enxertos ósseos do tipo 
onlay e 85 em enxertos do tipo inlay no soalho de seio maxilar. 833 destes implantes foram posicionados em blocos monocorticais cortico-medulares removidos da parte anterior medial ou posterior lateral da crista iliaca; os outros 38 implantes foram posicionados em enxertos ósseos de sínfise mandibular após 3 a 4 meses da cirurgia de enxerto. Uma perda de 74 implantes em 23 pacientes foi constatada, muitas delas ocorrendo devido a uma ausência de osseointegração no momento da conexão do intermediário ou a um afrouxamento assintomático nos primeiros meses pós-operatórios. Quando analisaram-se as perdas dos implantes relacionadas à anatomia dos rebordos, evidenciou-se que a maxila edêntula apresentava o maior índice no momento da avaliação, 48\%, enquanto que as mandíbulas edêntulas mostraram um índice de sucesso maior, $89,3 \%$. Os enxertos onlay de crista iliaca estavam associados ao menor índice de sobrevivência $(66,4 \%)$, seguido pelos enxertos sinusais de osso ilíaco $(70,5 \%)$, enxertos de sínfise mandibular tipo onlay $(75,0 \%)$ e inlay (100\%). O maior número de insucesso de implantes ocorreu em mulheres com idade entre 50 e 60 anos.

Outro fator que contribui para o sucesso dos implantes em regiões enxertadas se refere ao tempo em que são colocados após a enxertia. Neste ponto, os períodos variam, notando-se melhores 
resultados quando existe um intervalo entre a colocação do enxerto e os implantes (LEKHOLM et al. ${ }^{46}, 1999$; NEYT, et al. ${ }^{59}$, 1997; SANT'ANA73, 1997; TRIPLETT; SCHOW88, 1996).

Em trabalho de revisão de literatura desenvolvido por TOLMAN87, em 1995, relacionado à utilização de implantes osseointegrados combinados com enxertos ósseos autógenos oriundos de diversas áreas doadoras, verificou-se um maior indice de sobrevivência dos implantes quando colocados tardiamente em enxertos em bloco onlay na maxila, comparados aos instalados imediatamente, com valores de $81 \%$ e $87 \%$ de sucesso, respectivamente. Resultados opostos foram observados nos enxertos interposicionais em bloco, com índices de $85 \%$ de sobrevivência para os implantes imediatos e $81 \%$ para os tardios.

Preocupados com este fator, SHIROTA et al.81 avaliaram, em 1996, dez pacientes que haviam sofrido ressecções mandibulares e que foram reconstruídos com enxertos em bloco, particulado, medular e cortical em descontinuidades mandibulares, e enxertos particulados, medular e cortical, em defeitos mandibulares marginais, todos retirados do ílio. Considerando-se periodo de aguardo de 6 a 12 meses entre a reconstrução mandibular e a colocação dos implantes, os autores 
submeteram os indivíduos que receberam enxerto ósseo em bloco à biópsia da região após 12 meses da cirurgia, e os demais após seis meses. Como grupo controle, espécimes foram obtidos de mandíbulas não enxertadas de pacientes no momento da colocação dos implantes. Os espécimes foram avaliados pela análise microscópica e radiomicrografia. Como resultados, observou-se que os achados do estudo diferiram muito do grupo controle, indicando que este se encontrava em estádio intermediário do processo de remodelamento pós-enxerto. A morfologia óssea das biópsias realizadas após seis meses foi muito similar à do grupo controle, sendo o grau de reparo equivalente ao estádio final de processo de remodelação pósenxerto, em parte por estes enxertos terem sido colocados em defeitos menores. Estes resultados sugeriram a possibilidade de colocação mais precoce dos implantes nos enxertos particulados medular e cortical em defeitos mandibulares marginais que nos demais citados.

No mesmo ano, TRIPLETT; SCHOW88 descreveram várias técnicas de aumento de rebordos em maxila e mandíbula, entre as quais incluíam enxertos ósseos tipo onlay, veneer, inlay e com levantamento de seio maxilar, provenientes da crista iliaca ou sínfise mandibular. Associou-se a estes procedimentos, a fixação 
de implantes osseointegrados imediatos ou após 6 a 9 meses da cirurgia. Um total de 129 enxertos foram colocados em 99 pacientes, 41 do tipo onlay, 14 veneer e 74 inlay e com levantamento de seio maxilar. 117 alcançaram sucesso, correspondendo a um indice de 90,7\%. 364 implantes foram colocados nos enxertos. 320 obtiveram sucesso na osseointegração $(87,9 \%)$. Dos 134 implantes colocados simultaneamente aos enxertos, 22 fracassaram, ao contrário daqueles posicionados após período de 6 a 9 meses, com perda de 22 implantes dos 230 utilizados. A origem dos ossos enxertados, crista ilíaca e mento, não influiu significativamente no sucesso ou fracasso dos enxertos ou dos implantes neles colocados. A maioria dos insucessos ocorreu devido à infecção ou exposição do enxerto por deiscência de sutura.

NEYT et al.59, em 1997, apresentaram os resultados do tratamento de 17 pacientes que se submeteram à cirurgia para reabilitação de rebordo maxilar atrófico com combinação de levantamento de soalho de seio maxilar e blocos córticomedulares em forma de "L" fixados no rebordo. Os enxertos ósseos foram removidos da região posterior da crista iliaca. No seio maxilar utilizou-se osso medular misturado a hidroxiapatita, sendo algumas vezes colocado, também, nos vãos existentes entre 
os blocos. Após quatro meses, 14 pacientes receberam implantes osseointegrados do sistema IMZ nestas regiões e três pacientes receberam implantes Branemark. Na colocação dos intermediários de cicatrização, removeram-se dois implantes, e mais um após seis meses da reabilitação protética. Observou-se reabsorção óssea ao redor de seis implantes, sendo que em dois havia reabsorção óssea horizontal de cerca de $5 \mathrm{~mm}$. Ao redor de três implantes, via-se reabsorção óssea na face vestibular de 3 a $6 \mathrm{~mm}$. Alcançou-se, a partir destes resultados, 97,5\% de sucesso após seis meses da reabilitação protética. Os três implantes que não osseointegraram e aqueles que apresentaram perda óssea estavam situados nos enxertos ósseos da região anterior da maxila.

Maior indice de sucesso de implantes posicionados posteriormente à colocação dos enxertos em comparação às técnicas simultâneas foi também constatado por SCHLIEPHAKE, et al. apud SENNERBY; ROOS77, em 1997 e LEKHOLM et al. ${ }^{46}$, em 1999, apresentando indices de perdas de implantes de $32 \%$ e $23 \%$ para as colocações simultâneas e $3 \%$ e $10 \%$ para os implantes colocados num segundo tempo, respectivamente. 
Em 1999, KELLER; TOLMAN; ECKERT 39 realizaram estudo retrospectivo de 12 anos analisando 32 pacientes reabilitados com enxertos ósseos em bloco oriundos da crista ilíaca e implantes osseointegrados por apresentarem severa reabsorção maxilar. Vinte e oito pacientes receberam os implantes imediatamente à colocação do enxerto quando volume e qualidade óssea residual eram adequados para suportar o enxerto e permitiam a instalação simultânea de um número suficiente de implantes para a estabilização do mesmo; quatro pacientes receberam os implantes após período de 4 a 6 meses da enxertia em rebordos onde o osso residual estava parcial ou totalmente ausente, ou quando a qualidade deste não fornecia estabilidade para o enxerto. Um total de 204 implantes foram utilizados alcançando-se um indice de sobrevivência de $86,3 \%$. Não se observou, no entanto, diferença significativa dos resultados entre as técnicas de uma ou duas fases.

Resultados satisfatórios decorrentes da instalação imediata de implantes em enxertos autógenos são encontrados com menor freqüência, como no trabalho de ADELL et al. ${ }^{1}$, em 1990, quando descreveram uma técnica cirúrgica para colocação imediata de implantes osseointegrados em enxertos onlay de crista iliaca. Cento e vinte e quatro fixações foram colocadas em 23 pacientes, 
observados durante período 1 a 10 anos. Após quatro e cinco anos da reconstrução e reabilitação protética, verificaram-se indices de sucesso correspondentes a 75,3\% e 73,8\%, respectivamente, com perda óssea marginal anual de cerca de $0,1 \mathrm{~mm}$.

SAILER ${ }^{71}$, no ano de 1989, descreveu técnica alternativa para a reabilitação de maxilas severamente atróficas utilizando enxertos ósseos autógenos da crista iliaca combinados com osteotomia LE FORT I, colocação simultânea de implantes osseointegrados e sulcoplastia modificada, indicando tal procedimento para pacientes classe III, pela possibilidade de melhorar as relações intermaxilares comuns nestas situações. Cinco pacientes foram tratados com este novo procedimento, recebendo cada um deles sete implantes. Em três pacientes, houve o descobrimento dos implantes após 6, 8 e 11 meses; apesar disto, todos evoluíram satisfatoriamente. Decorridos 13 meses, não se observou reabsorção visível nas radiografias.

O nível de reabsorção óssea ocorrido nos enxertos de crista ilíaca com inserção imediata de implantes também foi motivo de análise para NYSTRÖM et al.60, em 1995, quando avaliaram tomografias computadorizadas de pacientes submetidos a este 
tipo de procedimento, em períodos pós-operatórios de 3 semanas, 3, 6, 12 e 24 meses. Verificou-se que as maiores alterações ósseas em altura ocorreram nos controles realizados durante o primeiro ano, perdendo-se cerca de $2 \mathrm{~mm}$ neste período. A maior perda em espessura óssea foi constatada durante os três primeiros meses, de cerca de $3,5 \mathrm{~mm}$. Em ambas, notou-se redução do índice de perda óssea após o primeiro ano pósoperatório.

No entanto, a utilização desta técnica apresenta resultados divergentes. ISAKSSON et al.33 apresentaram, em 1993, os resultados preliminares de 12 pacientes exibindo maxilas extremamente atróficas. Os enxertos ósseos foram removidos da crista iliaca em blocos de aproximadamente $2 \mathrm{~cm} \times 0,8 \mathrm{~cm} \times$ $0,8 \mathrm{~cm}$, nos quais, posteriormente, foram colocados 59 implantes. O período de acompanhamento pós-operatório variou entre 11 a 24 meses. Quatorze implantes não osseointegrados foram encontrados durante o primeiro ano de seguimento. Em dois pacientes, todos os implantes foram removidos após 9 e 11 meses. Nenhum implante foi perdido depois de iniciada a carga.

Com o mesmo intuito, LI; STEPHENS; GLIKLICH ${ }^{48}$; em 1996, avaliaram 20 pacientes submetidos à osteotomia LE FORT I 
com colocação interposicional de enxertos ósseos de crista ilíaca e implantes imediatos, tratados no período de 1990 a 1994 . Cento e trinta e cinco implantes foram inicialmente utilizados. Destes, 114 obtiveram sucesso após período de acompanhamento, variando de 13 a 62 meses, correspondendo a um indice de $82 \%$, comparável com outros autores cujos índices variavam de $70 \%$ a 95,4\% utilizando a mesma técnica. As perdas dos implantes ocorreram todas no primeiro ano pós-operatório em três pacientes, os quais apresentavam altura inicial de rebordo maxilar menor que $3 \mathrm{~mm}$.

Outras técnicas complementares também foram preconizadas, como a colocação dos enxertos em seios maxilares e soalho de fossa nasal, a fim de se evitar maiores reabsorções notadas nos enxertos onlay. JENSEN; SIMONSEN; SINDETPEDERSEN ${ }^{36}$, em 1990, realizaram tal procedimento instalando 36 implantes em regiões de enxerto com osso ilíaco, em cinco pacientes, com tempo de observação de 10 a 29 meses. Nove destes implantes não osseointegraram, sendo que duas reconstruções foram perdidas em períodos de 2 e 23 meses após iniciada a carga. 


\title{
2.2 Reparo dos enxertos ósseos autógenos não vascularizados
}

\begin{abstract}
O material utilizado para substituir a porção óssea alveolar de rebordos edêntulos pode atuar no osso receptor por meio de três mecanismos biológicos, dependendo de sua origem e composição: osteocondução, osteoindução e osteogênese (LEE ${ }^{44}$, 1997; LEVIN, et al.47, 1995; MARX $^{49}, 1994 ; \mathrm{MISCH}^{53}, 1993$; RABIE; LIE KEN JIE68, 1996).
\end{abstract}

A osteocondução caracteriza-se pela formação de novo osso por sobre um arcabouço de substância biológica ou aloplástica, a partir de células osteogênicas do osso já existente49,53. Exemplos de materiais osteocondutores são a hidroxiapatita, o osso congelado, o óxido de alumínio e o óxido de titânio.

A capacidade de um material induzir a transformação de células indiferenciadas mesenquimais em osteoblastos ou condroblastos, em uma região onde espontaneamente isto não ocorreria, denomina-se osteoindução (MARX ${ }^{49}, 1994 ;$ MISCH$^{53}$, 1993), cuja maior contribuição para a formação óssea ocorre 
durante o processo de remodelação. Os aloenxertos são os mais representativos.

O osso autógeno é o único material disponivel com comportamento osteogênico (CITARDI et al. ${ }^{13}, 1994$; MISCH${ }^{53}$, 1993; VASCONCELOS et al.92, 1999). Sua capacidade de formar tecido ósseo mesmo na ausência de células mesenquimais indiferenciadas caracteriza esta qualidade, pois compõe-se de células ósseas viáveis, as quais produzem grandes quantidades de fatores de crescimento para a formação do tecido ósseo. Estas, por sua vez, encontram-se em maior concentração nas porções do trabeculado ósseo, favorecendo a utilização de ossos predominantemente medulares como o ilio e a costela. Por outro lado, as porções corticais constituem a fonte primária das proteínas ósseas morfogenéticas (BMPs) (DeLACURE16, 1994; SAKOU 72 , 1998), predominando em ossos como a sinfise mandibular e a calvária.

O mecanismo de reparação dos enxertos ósseos autógenos incluem estes três processos, elucidados nos trabalhos de MISCH $^{53}$, 1993; MARX ${ }^{49}$, 1994; DE LACURE16, 1994 e MARX, GARG50, 1998. As células osteoblásticas e as mesenquimais presentes no fragmento ósseo transferido conseguem sobreviver 
nos 3 a 5 primeiros dias, produzindo, este periodo, pequena quantidade de tecido osteóide na superfície das trabéculas do osso enxertado; além disto, ilhas de osso medular mineralizado, fibrina e plaquetas também são transportados. A partir deste período, inicia-se uma invasão de capilares no enxerto proveniente dos tecidos moles e superfícies ósseas do osso receptor, estimulados pela liberação de fatores angiogênicos derivados de macrófagos recrutados. As plaquetas, por sua vez, liberam fatores de crescimento iniciando a angiogênese a partir dos capilares circunjacentes e estimulando a mitose das células osteocompetentes presentes no enxerto. Nas fases iniciais, a fonte de suprimento sangüineo e o contingente celular são imprescindiveis. Após o restabelecimento da vascularização, esta produção aumenta, possivelmente resultante da viabilidade de oxigênio e nutrientes. No decorrer da terceira e quarta semanas, a união entre o osteóide do osso enxertado e do receptor constitui a consolidação do enxerto, utilizando a rede de fibrina como arcabouço.

À medida que ocorre a reabsorção do tecido ósseo, há liberação das BMPs e de outras proteínas que atuarão sobre as células osteoblásticas e mesenquimais indiferenciadas. Novo tecido ósseo também pode se formar por sobre o arcabouço do 
osso enxertado enquanto é produzido (FEIFEL; RIEDIGER; WEISKE22, 1994; TRUETA ${ }^{89}$, 1963).

Segundo YASZEMSKI, et al. ${ }^{97}$, a seqüência de incorporação dos enxertos ósseos medular e cortical assemelham-se durante as duas primeiras semanas. Os eventos de revascularização diferem entre si, sendo mais rápidos nos ossos medulares. Nestes, a revascularização acontece através dos espaços medulares, e nos ossos corticais, ocorre pelos canais Haversianos. O crescimento de novos vasos sangüíneos no interior dos canais de Havers se faz de maneira mais lenta do que nos espaços abertos medulares.

Em resposta às demandas funcionais a que os rebordos e os enxertos são submetidos, o novo osso formado é substituído por sistemas de Havers maduros e osso lamelar, os quais sofrerão um longo processo de remodelação consistente com o do esqueleto normal, capazes de suportar as forças normais que incidem sobre os rebordos, de acordo com MARX; GARG ${ }^{50}$, em 1998.

Uma quantidade considerável de trabalhos focalizando a fisiologia óssea e o processo de reparo dos enxertos autógenos é encontrada na literatura pertinente, indicativos da importância de tais conhecimentos aplicados aos procedimentos clínicos. 
Um dos mais importantes e elucidativos foi desenvolvido por ALBREKTSSON³, em 1980, o qual, não satisfeito com as análises microscópicas estáticas existentes até então, utilizadas para avaliar o processo de reparo dos enxertos ósseos corticais e medulares, utilizou o que denominou de método microscópico vital, instalando câmaras de titânio ocas, separadas por duas esferas de vidro numa distância de $100 \mathrm{~mm}$, nas metáfises de tíbias de coelhos, a fim de estudar de maneira dinâmica in vivo e in situ os diferentes estádios do processo de reparo dos enxertos ósseos. Para que isto fosse possivel, a câmara e o osso circunjacente foram removidos com o auxilio de uma broca trefina e enxertados em outra extremidade, ou reinseridos no mesmo local. Os enxertos medulares apresentaram início de revascularização aos 15 dias pós-cirúrgicos e término no $20^{\circ}$ dia, quando então, evidenciou-se o processo de osteogênese e o aumento de massa óssea trabecular. Os enxertos corticais apresentaram revascularização mais lenta, completada no $30^{\circ}$ dia. Neste periodo, as fases de reabsorção e osteogênese ocorreriam concomitantemente no mesmo enxerto. As cavidades menores foram preenchidas por osso primário, ao mesmo tempo em que outras eram criadas. Aos 35 e 40 dias, a fase osteogênica já havia sido superada pela reabsorção, até que a massa óssea reduzisse significativamente, para que outra fase osteogênica 
predominasse. Calculou-se o indice máximo de penetração vascular nos enxertos medulares e corticais, obtendo-se os valores de $0,2 \mathrm{~mm} /$ dia a $0,4 \mathrm{~mm} /$ dia e $0,15 \mathrm{~mm} /$ dia a $0,3 \mathrm{~mm} / \mathrm{dia}$, respectivamente. Aproximadamente, a mesma densidade vascular existente anteriormente à colocação do enxerto foi necessária para que a remodelação óssea acontecesse.

Para que os eventos de incorporação dos enxertos autógenos sigam o curso normal, alguns cuidados são necessários a fim de se manter a integridade do fragmento ósseo a ser utilizado. Sabe-se que um fator importante que interfere no processo de reparo ósseo é o trauma nele causado durante sua manipulação, principalmente durante as técnicas de osteotomia (ALBREKTSSON ${ }^{4} ，$ 1980; OKAMOTO; YAMAMOTO; SONODA61, 1994). O mesmo sucede nos procedimentos de enxertia óssea.

Confirmando esta teoria, ALBREKTSSON 4 , em 1980, realizou um trabalho em coelhos para verificar a resposta dos tecidos a receberem enxertos ósseos frente a vários níveis de trauma, além de observar a velocidade de revascularização e remodelação óssea na área receptora. A sobrevivência dos enxertos foi testada por meio de análise histoquímica uma vez que a simples presença de osteócitos nas lacunas não confirmava 
a viabilidade óssea. Verificou-se que o tempo de revascularização foi proporcional à intensidade do trauma; ou seja, quanto maior o trauma, maior o tempo para o início da revascularização e, conseqüentemente, da remodelação óssea. A análise histoquímica demonstrou que apenas os enxertos minimamente traumatizados apresentaram atividade da enzima diaforase, sendo esta produzida apenas por células metabolicamente ativas.

Opiniões divergentes encontradas pelo mesmo autor (ALBREKTSSON 5 , 1982) com relação ao tempo máximo de tolerância do tecido ósseo à isquemia, fizeram com que ele analisasse, no ano de 1982, a condição de isquemia e o processo de revascularização de enxertos ósseos livres autógenos realizados em coelhos utilizando a mesma metodologia de microscopia vital empregada para observação dos eventos de reparação óssea. Todas as conexões vasculares dos 20 enxertos analisados foram completamente interrompidas e a condição de isquemia definida. Verificou-se que os enxertos mais lentamente revascularizados eram aqueles cujo trauma cirúrgico havia sido maior, apresentando déficit de cinco a seis dias em comparação àqueles dez mais cuidadosamente manipulados. A análise histoquímica de cinco destes enxertos demonstrou completa morte celular; os cinco remanescentes foram seguidos por um 
período de um ano, quando se observou que partes daqueles ossos ainda estavam sem revascularização. Destacou-se neste estudo, que a condição isquêmica dos tecidos não foi a única ameaça aos enxertos ósseos, uma vez que as atividades do cirurgião foram igualmente nocivas. Nos enxertos ósseos livres, várias células conseguiram suportar um período limitado de isquemia; a revascularização ocorrendo em quatro a cinco dias pareceu ser o suficiente para sua sobrevivência. Os estudos realizados com câmara de garrote, onde dois clamps obstruiam temporariamente as vias vasculares, evidenciaram que o tecido ósseo não conseguiu sobreviver cinco dias sem suprimento sangüíneo.

Os métodos de armazenamento dos enxertos podem determinar as condições de viabilidade de seu contingente celular. STEINER; RAMP85, em 1988, testaram vários meios de armazenamento para enxertos ósseos autógenos e seus efeitos sobre o metabolismo de glicose e síntese de colágeno. Usaram soro fisiológico a 0,9\%, água destilada e dextrose 5\% em solução Ringer lactato. O estudo sugeriu que os enxertos deveriam ser armazenados em soro fisiológico ou dextrose $5 \%$ em solução Ringer lactato por até cinco horas. A água destilada não foi recomendada. Além disto, a temperatura do meio de 
armazenamento exerce influência sobre as células. MARX; SNYDER; KLINE51, em 1979, documentaram que 94\% da viabilidade celular é mantida até quatro horas de armazenamento em temperatura ambiente. Soluções com temperaturas elevadas aumentam o índice de morte das células devido à demanda elevada de oxigênio. Apesar das temperaturas menores que a ambiente não serem comumente aceitas, acredita-se que estejam associadas a um discreto aumento no índice de sobrevivência celular.

\subsection{Origem dos enxertos ósseos}

A área doadora escolhida com maior freqüência para a reconstrução de rebordos maxilares e mandibulares é, sem dúvida, o ílio, preferido por suas características morfológicas e estruturais, constituído por grande quantidade de osso esponjoso (ADELL et al. ${ }^{1}, 1990$; KELLER et a1.40, 1987; LEKHOLM et a1.46, 1999; MARX ${ }^{49}$, 1994; TOLMAN 87, 1995). Apesar de tais qualidades, o ilio origina-se de uma ossificação do tipo endocondral, fato ao qual se atribui o alto índice de reabsorção sofrido por este tipo de enxerto. Outras áreas foram buscadas, como a mandíbula e a calvária, cujos tecidos ósseos originam a 
partir de uma ossificação intramembranosa, semelhante à área receptora em questão (MISCH${ }^{55}, 1997$; MISCH; MISCH56, 1995; MISCH et al.57, 1992; PINHOLT et al.67, 1994; RISSOLO; BENNETT69, 1998).

Alguns autores consideram a classificação quanto à origem do enxerto ósseo como sendo um fator de relevância na incorporação e manutenção de volume do mesmo.

Baseados em observações clínicas que sugeriam a menor reabsorção dos enxertos ósseos intramembranosos em comparação aos endocondrais, ZINS; WHITAKER98, em 1983, compararam estes dois tipos de enxertos em coelhos e macacos, utilizando microscopia de fluorescência e técnicas de contagem de pontos. Participaram 15 coelhos Nova Zelândia adultos e sete macacos, os quais receberam enxerto ósseo autógeno nas regiões de ossos nasais e crânio, respectivamente. Em todos os animais administraram-se corantes vitais. Os coelhos foram sacrificados nos períodos pós-operatórios de 5, 10 e 2 semanas, e os macacos após 8 e 12 semanas. Em ambos os grupos, o osso intramembranoso manteve seu volume de maneira muito mais satisfatória. Ao final do experimento, a perda de volume dos enxertos endocondrais foi três vezes maior que a dos 
intramembranosos nos coelhos e quatro vezes maior no grupo dos macacos. Observou-se presença mais evidente dos corantes nos ossos intramembranosos. A técnica de contagem de pontos também mostrou maior quantidade de tecido ósseo viável neste grupo. Este trabalho confirmou a crescente reabsorção óssea dos enxertos endocondrais quando comparados com os intramembranosos e ainda confirmou as impressões clínicas de que áreas doadoras do crânio são preferiveis para áreas receptoras na região craniofacial.

Estes padrões de comportamento levaram os autores KUSIAK; ZINS; WHITAKER 41 a compararem, no ano de 1985, a vascularização dos enxertos ósseos onlay de origem endocondral e intramembranosa, sugerindo assim, que este poderia ser um dos fatores que justificasse tal comportamento. Para isto, utilizaram 25 ratos adultos Nova Zelândia, os quais receberam enxertos em bloco provenientes do ílio e do zigoma, ambos posicionados no osso nasal. Estes animais foram sacrificados em períodos de 1, 3, 7, 14 e 21 dias após o recebimento do enxerto. As artérias carótidas comuns dos animais foram expostas para que se fizesse a injeção de material de contraste. Após quatro horas, os enxertos ósseos juntamente com o osso nasal foram retirados e preparados para análise microscópica. Em um dia, não se via 
penetração vascular em nenhum dos enxertos, apesar de que, quantitativamente, pôde-se notar maior número de brotos vasculares crescendo em direção ao enxerto intramembranoso. Uma vascularização mais rápida deste osso foi evidente no terceiro dia pós-operatório, por meio do crescimento de vasos a partir do periósteo e do osso subjacentes, embora nas primeiras fases da vascularização predominassem os componentes do tecido mole, também vista no sétimo dia. No $14^{\circ}$ dia, ambos os enxertos apresentavam-se extensivamente vascularizados, apesar do enxerto endocondral ainda mostrar uma área central não vascularizada, persistindo no $21^{\circ}$ dia. Estes resultados demonstraram que a morfologia do osso intramembranoso, composto por uma densa superfície cortical, não representou uma barreira física ao rápido crescimento dos vasos locais. Porém, a explicação para esta vascularização precoce permaneceu obscura para os autores.

A conseqüência desta rápida revascularização ocorrida nos enxertos ósseos intramembranosos levaria a um processo osteogênico aumentado, atribuindo-se a estes fatos a melhor manutenção do volume ósseo nestes tipos de enxertos. Pensando nisto, SOLHEIM et al.83, no ano de 1995 , se propuseram a investigar quantitativamente a formação de novo osso em 
enxertos ósseos frescos da calvária, mandíbula, tíbia e ílio, implantados heterotopicamente nos músculos dorsais de ratos, por meio de análise de recuperação com estrôncio 85. Foram utilizados 107 ratos, os quais tiveram enxertos ósseos provenientes de outros sete ratos implantados em seus dorsos. O sacrifício dos animais sucedeu no terceiro dia pós-operatório, tendo estes recebido, quatro dias antes, injeção de $10 \mathrm{mCi} / 100 \mathrm{gm}-85 \mathrm{Sr}$ como $\mathrm{SrCl}_{2}$, para que se pudesse calcular a atividade isótopa das amostras. Verificou-se assim, que a nova formação óssea, analisada pelo índice osteogênico do 85Sr foi maior nos enxertos de calvária e mandibulares, comparados com os de tíbia, mas semelhante entre calvária, mandibula e ílio.

Apesar destes e de outros estudos favorecerem os enxertos intramembranosos atribuindo a origem dos mesmos a este fato, existem aqueles que contradizem tal teoria e resultados dando ênfase a diferentes observações.

HARDESTY; MARSH ${ }^{29}$, realizaram no ano de 1990, um estudo utilizando blocos de enxertos monocorticais e bicorticais provenientes da crista ilíaca e calvária posicionados nos ossos nasais de coelhos dando especial atenção à morfologia e orientação no posicionamento na área receptora. Três orientações 
distintas foram usadas em cada animal: cortical e medular em contato com o osso receptor e bloco bicortical. Após períodos de 45 dias e três meses, 21 e 25 coelhos foram sacrificados, respectivamente. Utilizando dados de quantificação e parâmetros comparativos, observou-se que durante o intervalo dos sacrifícios os enxertos membranosos realmente persistiam ou aumentavam seu volume, enquanto que os endocondrais reabsorviam. Porém, a estes resultados, os autores atribuíram a diferença estrutural dos diferentes tipos de enxertos pelas proporções entre osso cortical e esponjoso, postulando que os mesmos mecanismos fisiológicos de reabsorção e incorporação óssea afetavam igualmente os enxertos ósseos autógenos independente de sua origem, associando os eventos microscópicos às evidências clínicas.

Em discussão do mesmo artigo, GLOWACKI 27 apresentou-se contra a utilização dos termos intramembranoso ou endocondral no que se refere a enxertos ósseos, por estes darem uma falsa impressão de relevância para os diferentes resultados apresentados, fundamentando-se no fato de que uma quantidade considerável dos trabalhos não examina os eventos iniciais da incorporação do enxerto. 
No ano de 1991, SULLIVAN; SZWAJKUN86 compararam a revascularização de enxertos ósseos oriundos da crista ilíaca e da calvária, autoclavados, desmineralizados e frescos, em 30 ratos Sprague-Dawley. Os enxertos foram posicionados nos ossos nasais e tíbia dos animais, divididos em três grupos. O primeiro grupo recebeu blocos de enxertos ósseos medindo $8 \mathrm{~mm}$ x $6 \mathrm{~mm}$ desmineralizados em $\mathrm{HCl} 0,6 \mathrm{~N}$. no segundo grupo, cada enxerto foi autoclavado a $250^{\circ} \mathrm{C}$ por 10 minutos. O terceiro grupo recebeu enxerto fresco. Cada animal recebeu enxertos ósseos da crista ilíaca e da calvária no focinho e na tíbia. Metade dos animais foi sacrificaas após sete dias e a outra metade após 14 dias. A área receptora do osso nasal foi avaliada aos 7 e 14 dias, e a da tíbia aos 14 dias. Silicona vermelha foi então injetada nas veias jugular interna e cava para que se pudesse visualizar a vascularização local. Notou-se que aos 7 e 14 dias no osso nasal e aos 14 dias na tíbia, a revascularização apresentou-se estatisticamente maior nos enxertos de crista ilíaca que nos de calvária, tanto no grupo dos enxertos frescos como nos desmineralizados e autoclavados.

Opondo-se à teoria de que a origem dos enxertos ósseos fosse a causa as diferenças na sua revascularização, PINHOLT et a1.67, em 1994, estudaram o comportamento de enxertos ósseos 
frescos da calvária, mandíbula, tíbia e ílio posicionados nos músculos dorsais de ratos Lewis. A revascularização dos enxertos era analisada três semanas após a cirurgia, por intermédio de depósito de microesferas marcadas com cério injetadas na aorta ascendente dos animais imediatamente após o sacrifício destes. A radioatividade total do isótopo nas amostras foi contado em um espectômetro de cintilação auto-gama. Observou-se que a revascularização dos enxertos recuperados foi maior nos enxertos mandibulares e de osso ilíaco, comparados com os de tíbia e calvária. Não se observou diferença entre os enxertos mandibular e de crista ilíaca ou entre a tíbia e a calvária, levando os autores a inferirem que a origem embriológica dos enxertos ósseos não seja a causa das diferenças encontradas na revascularização, mas possivelmente, pelas diferenças na proporção de osso cortical e medular.

Em 1995, ALONSO et al. ${ }^{6}$ compararam os resultados da utilização de enxertos de calvária e crista ilíaca no osso nasal de 60 coelhos Nova Zelândia com idades entre 8 a 12 meses. Dois grupos foram determinados: Grupo C, composto por coelhos enxertados com osso oriundo da calvária e Grupo I, composto por coelhos enxertados com osso oriundo da crista ilíaca. Estes dois grupos foram subdivididos em seis, de acordo com os períodos do 
sacrifício: $18,30,60$ dias. Por meio de análise histomorfométrica dos enxertos, os quais foram previamente medidos e pesados, os autores verificaram que os enxertos da calvária tiveram seu peso e volume mantidos após 60 dias, o que não se observou nos da crista iliaca. Seguindo o mesmo raciocinio de HARDESTY; MARSH ${ }^{29}$, sugeriu-se que a perda de massa e volume ósseo ocorrida nos enxertos de crista iliaca pudesse estar associada a um desequilíbrio no processo de remodelação deste osso e não à sua origem embriológica. E ainda, que os resultados a longo prazo dos enxertos onlay fossem determinados por suas próprias características osteogênicas durante a fase inicial da incorporação, a qual atua em resposta às alterações no estímulo mecânico provenientes de seu meio.

Tais resultados levaram ao desenvolvimento de diversos estudos clínicos utilizando enxertos intramembranosos, provenientes de regiões mandibulares e calvária, predominantemente.

SINDET-PEDERSEN; ENEMARK 82 , já no ano de 1988, experimentaram o uso de enxertos ósseos intramembranosos oriundos da sínfise mandibular para reconstrução de fissuras alveolares, selecionando 28 pacientes com idade média de dez 
anos para avaliar tais resultados. Vinte e cinco pacientes apresentavam somente fissura labial e alveolar e três apresentavam fissura unilateral labial e palatal. Em 20 pacientes, a cirurgia foi realizada antes da erupção dos caninos superiores. Após seis meses, a área enxertada apresentou, radiograficamente, arquitetura normal em todos os casos, e a morfologia do processo alveolar reconstruido foi considerada satisfatória. Todos os caninos erupcionaram na presença do enxerto e nenhum dano aos dentes da região doadora ou do nervo mentoniano foi relatado. Este periodo, no entanto, foi curto para se afirmar que os enxertos intramembranosos mantiveram maior quantidade de seu volume e foram mais rapidamente vascularizados que os endocondrais. A maior vantagem descrita pelos autores no uso de enxertos ósseos mandibulares foi a facilidade de acesso, tempo cirúrgico reduzido, menor custo econômico e acesso unicamente intrabucal.

Os resultados satisfatórios obtidos por BORSTLAP8 et al., em 1990, também apontaram o mento como a área doadora de primeira escolha em comparação com a costela nas reconstruções de fissuras palatinas, com $15,7 \%$ dos casos de enxerto de costela apresentando $50 \%$ ou mais de reabsorção óssea. Tais resultados foram obtidos a partir de um estudo realizado entre os anos de 
1981 e 1988, onde os autores avaliaram o tratamento de 61 pacientes com idade média de 9,5 anos. Nenhuma complicação como deiscência de sutura, reabsorções excessivas ou recorrência de fístulas oronasais foi constatada decorrente dos procedimentos de enxertia, tanto da costela, como do mento.

HOPPENREIJS; NIJDAM; FREIHOFER ${ }^{31}$, no ano de 1992, apresentaram trabalho que avaliou clínica e radiograficamente o mento como área doadora em osteoplastias secundárias em crianças. Dentre os objetivos, buscou-se verificar a morbidade causada após a remoção dos enxertos, os efeitos nos dentes incisivos e caninos mandibulares, além do crescimento ósseo na área doadora. Vinte e seis pacientes com idade variando de 8,5 a 11,9 anos submetidos a enxertos ósseos autógenos oriundos da região mentoniana para reconstrução secundária do processo alveolar foram observados. Estes pacientes foram examinados em consultas de retorno que variavam entre 1 a 4,5 anos, após a cirurgia, para análises clínica e radiográfica. Clinicamente, observava-se a condição periodontal, condições do esmalte dos dentes erupcionados e sensibilidade pulpar. Radiograficamente, buscava-se na região doadora a presença de lesões periapicais, obliterações pulpares, reabsorções radiculares e distúrbios do desenvolvimento. Durante as avaliações não se observou retração 
gengival ou presença de bolsa periodontal. Negatividade de resposta pulpar foi encontrada em 23 dentes, num total de 146 dentes presentes para avaliação. Em um incisivo notou-se a presença de radiolucência periapical. Dezoito dentes mostraram obliteração pulpar. Dois dentes apresentaram defeitos no esmalte e um dente mostrou rizogênese incompleta. Em 21 pacientes, a área doadora apresentou-se completamente recuperada.

A mesma zona doadora foi avaliada por MISCH et al. ${ }^{57}$, no ano de 1992, em 11 pacientes parcialmente edêntulos na maxila, apresentando osso inadequado para futura instalação de implantes osseointegrados. Para o restabelecimento destas áreas, todos estes pacientes receberam enxertos ósseos em blocos, provenientes da região mentoniana. Decorridos quatro meses da enxertia, as respectivas áreas foram então expostas para a colocação dos implantes, revelando uma densidade maior que o do osso circunjacente e semelhante à região de sínfise mandibular.

Vantagens e desvantagens da utilização desta área doadora em comparação a outras já foram demonstradas, como nos estudos de MISCH; MISCH${ }^{56}$, de 1995 e GARG et al.26, de 1998, quando apresentaram os resultados de defeitos ósseos alveolares 
localizados reabilitados com enxerto ósseo autógeno mandibular da região mentoniana, para fins de colocação de implantes osseointegrados. Nestes trabalhos, enfatizam-se os aspectos positivos do mento como sua origem, índice de reabsorção reduzido e facilidade cirúrgica. Destacam-se também, desvantagens como a quantidade de osso que pode ser removido da região e a possibilidade de injúrias aos ramos nervosos e aos dentes relacionados. Prejuízos com relação à estética não foram encontrados, como ptose do mento, evitando-se demasiado afastamento dos tecidos moles. O tipo de incisão deve ser cuidadosamente selecionado levando-se em conta a condição periodontal dos dentes relacionados, assim como a área a sofrer osteotomia. Apesar destes cuidados, podem acontecer alterações na sensibilidade dos dentes e outras alterações como os citados por HOPPENREIJS; NIJDAM; FREIHOFER ${ }^{31}$.

Ainda MISCH55, em 1997, comparou a utilização de enxertos ósseos autógenos mandibulares removidos da região do mento e do ramo mediante avaliações clínicas. Enxertos ósseos autógenos em bloco foram utilizados em 55 pacientes, sendo os oriundos do mento apresentando-se como cortico-medulares e os oriundos do ramo mandibular, corticais. Após período de 4 a 6 meses, procedeu-se a colocação dos implantes. A quantidade de 
reabsorção foi medida nas cabeças dos parafusos de fixação e na crista alveolar. A incorporação do enxerto foi avaliada seguida da remoção dos parafusos de fixação e a quantidade óssea durante a realização das perfurações no preparo para a colocação dos implantes. O sucesso da técnica de aumento de rebordo foi determinada pela colocação dos implantes. Todos os enxertos onlay foram incorporados e não houve diferença clínica significante de reabsorção entre os tipos de enxerto. A área de ramo mandibular forneceu um enxerto essencialmente cortical, ajustando-se satisfatoriamente em deficiências veneer. A qualidade óssea foi graduada, em média, como osso tipo I para os enxertos de ramo e tipo II para os enxertos de sinfise, sendo que nenhum deles apresentaram-se do tipo III ou IV45. Os implantes foram colocados com sucesso em todos os locais planejados.

Estudos clínicos comparativos utilizando enxertos endocondrais e intramembranosos também vêm sendo extensivamente desenvolvidos.

A fim de avaliar os resultados da utilização de enxertos ósseos autógenos da crista ilíaca e da calvária em fissuras alveolares e palatinas, LA ROSSA et al. ${ }^{42}$, em 1995, analisaram 116 pacientes, 76 portadores de fissura unilateral e 40 bilateral. 
A calvária foi a área doadora em 60 pacientes e a crista ilíaca em 56. A qualidade dos enxertos foi graduada pela análise radiográfica, iniciada no período de seis meses após a cirurgia. Apesar dos resultados obtidos em estudos similares, onde os enxertos de origem intramembranosa superaram os endocondrais, neste trabalho verificou-se a superioridade dos enxertos de crista ilíaca sobre os de calvária, especialmente nos defeitos severos.

A origem dos enxertos ósseos não pareceu exercer influência significativa na sobreviência dos implantes nas análises dos índices de sobrevivência de 786 implantes colocados em enxertos de diferentes origens feitas por SCHLIEPHAKE; NEUKAM; WICHMANN76 em 1997. O maior número de insucesso foi constatado em mulheres com idades variando de 50 a 60 anos. Algumas hipóteses foram aventadas para justificar tais resultados, dando-se ênfase às alterações hormonais pósmenopausa no metabolismo ósseo associadas à utilização de enxertos da crista ilíaca.

A análise dos trabalhos referentes a este assunto sugere a existência de fatores outros que possam estar relacionados aos resultados divergentes encontrados. Imagina-se ser a estabilidade dos enxertos ósseos um fator preponderante no sucesso de sua 
incorporação, diminuindo a possibilidade de movimentações, melhorando a distribuição de forças sobre o enxerto e, conseqüentemente, a revascularização local.

Seguindo este raciocínio, PHILLIPS; RAHN63 no ano de 1990, investigaram a relação entre reabsorção e revascularização óssea e a fixação de enxertos ósseos autógenos de origem membranosa e endocondral. Para tanto, utilizaram 20 carneiros adultos, os quais receberam enxertos autógenos em bloco oriundos da calvária e costela, com dimensões de $30 \mathrm{~mm}$ x $10 \mathrm{~mm}$ x $4 \mathrm{~mm}$, posicionados bilateralmente na borda mandibular, anterior ao músculo masseter. Naqueles que foram fixados, utilizaram-se parafusos do sistema AO de $1,5 \mathrm{~mm}$ em cada extremidade do enxerto. As quatro combinações de enxertos intramembranosos e endocondrais fixados e não fixados foram realizadas. Dez animais foram sacrificados após duas semanas, e os outros dez restantes, após 20 semanas. Os animais sacrificados após duas semanas receberam injeções de corantes vitais calcein green uma semana anteriormente ao sacrifício, e procion red e india ink no momento do sacrifício. Os animais do grupo de 20 semanas receberam injeções com corantes vitais uma vez por semana nos seguintes intervalos: xylenol orange desde a primeira até a sexta semana; calcein green da $7^{\mathrm{a}}$ à $1^{4^{\mathrm{a}}}$ semana e 
tetraciclina da $14^{a}$ quarta a 19a semana. No momento do sacrifício, receberam injeções com disulfine blue e india ink, a fim de se estudar a extensão da revascularização. Nos animais sacrificados após duas semanas, os enxertos membranosos fixados demonstraram $15,5 \%$ de revascularização com o india ink e os não fixados $6,2 \%$. Os enxertos endocondrais não fixados já mostraram 24,4\% de revascularização e os fixados, 42,4\%. O procion red mostrou que os enxertos membranosos fixados alcançaram $85,5 \%$ de revascularização, e os não fixados $62,4 \%$, contra os endocondrais fixados, $85,2 \%$, e não fixados, $98,1 \%$. Após período de 20 semanas verificou-se que, independente do volume de reabsorção ou tipo de enxerto, todo o osso presente mostrava-se totalmente revascularizado, visualizado pela +infiltração de disulfine blue e india ink.

O comportamento dos enxertos de diferentes origens embriológicas também já foi testado em técnicas de regeneração tecidual guiada (RTG), largamente utilizada em procedimentos de periodontia, tendo, nos últimos tempos, sua utilização voltada para os implantes osseointegrados. ALBERIUS; DAHLIN; LINDE2 em 1992, realizaram estudo de incorporação e integração de enxertos ósseos de origem endocondral e intramembranosa em áreas da mandíbula e calvária, com e sem a utilização de 
membranas, a fim de analisar a capacidade osteopromotora do uso de membranas em conjunto com enxertos ósseos corticomedulares inlay e onlay. As cirurgias foram realizadas em 28 ratos Sprague-Dawley e os espécimes removidos e analisados microscopicamente após 12 meses. Os enxertos de origem embriológica intramembranosa apresentaram integração óssea satisfatória ao osso circunjacente, quando protegidos pela membrana. Já nos de origem endocondral, mesmo com o uso da membrana, foi possivel visualizar a formação de uma delicada camada de tecido conjuntivo fibroso circundando o enxerto e separando-o do osso adjacente. Na ausência da membrana, os resultados obtidos foram bastante semelhantes, tanto para os enxertos intramembranosos como para os endocondrais, observando-se discreta reabsorção com mínima deposição óssea nas margens dos defeitos, além da presença de uma cápsula fibrosa circundando o enxerto. Verificou-se, assim, que o recrutamento de células osteogênicas foi promovido pelo uso das membranas contribuindo para a aceleração da disposição óssea ao redor dos enxertos. A utilização desta técnica, além das vantagens já discutidas, evitaria que grandes quantidades de osso fossem removidas das áreas doadoras, beneficiando especialmente pacientes pediátricos. 


\section{PROPOSIÇÃO}

Propõe-se neste trabalho:

1. Analisar, à luz da microscopia óptica, a condição de reparo presente em regiões de rebordos alveolares maxilares reconstruídos com enxertos ósseos autógenos no período pósoperatório de quatro meses;

2. Avaliar, comparativamente, a qualidade óssea resultante destes procedimentos, relacionando-a aos dois tipos de enxertos. 


\section{MATERIAL E MÉTODOS}

Neste trabalho, empregou-se a análise microscópica de fragmentos ósseos de segmentos alveolares maxilares reconstruídos com enxertos da região de osso ilíaco e sínfise mandibular, buscando-se informações quanto aos fenômenos de reparo dos enxertos e qualidade óssea do local. Para tanto, pacientes espontaneamente integraram a amostra, fornecendo dados clínicos suficientes para a correlação dos achados microscópicos (ANEXO A).

Optou-se, para melhor entendimento desta metodologia, dividí-la em tópicos.

\subsection{Procedimentos cirúrgicos e obtenção das amostras}

As amostras procederam de pacientes atendidos na Clinica de Cirurgia e Traumatologia Bucomaxilofacial do Curso de Odontologia da Universidade do Sagrado Coração de Bauru e consultórios particulares. 
Dez individuos, sendo cinco homens e cinco mulheres, com idades variando de 28 a 67 anos, foram submetidos à reconstrução de áreas atróficas de rebordo alveolar maxilar com utilização de blocos de enxertos ósseos autógenos provenientes da crista iliaca ou sinfise mandibular (Tabela 1 ).

Os defeitos alveolares tratados corresponderam às classes IV, V e VI, segundo classificação de CAWOOD; HOWEL 12 (1988), apresentando deficiência de espessura e altura óssea, impossibilitando a colocação de implantes osseointegrados.

A opção pela zona doadora baseou-se na dimensão do defeito e volume de enxerto necessário. Nos procedimentos, onde se buscou o ílio como zona doadora, empregou-se a anestesia geral em ambiente hospitalar. Nos casos de enxerto mandibular, a anestesia local foi escolhida e realizada em ambiente ambulatorial. Em apenas um destes associou-se à anestesia local, sedação endovenosa em ambiente hospitalar.

Todos os pacientes foram submetidos à anamnese detalhada e exames laboratoriais de rotina, além de consulta pré-anestésica quando da utilização de anestesia geral. Não se encontrou, 
nestes, nenhuma alteração sistêmica que pudesse interferir na condução do caso ou prognóstico do tratamento.

Os procedimentos cirúrgicos foram conduzidos obedecendose rígidas regras de manutenção de cadeia asséptica e dentro dos princípios básicos de técnica operatória. Em todos os casos, independentemente da zona doadora, buscou-se a exposição do leito receptor por meio de incisões praticadas na crista alveolar maxilar, estendendo-se aos dentes vizinhos pelo sulco gengival e evitando-se o uso de incisões verticais ou oblíquas. A superfície óssea do defeito foi exposta às custas de amplos descolamentos mucoperiostais, o que permitiu a visualização da dimensão do enxerto necessário. Após este tempo cirúrgico, partiu-se para o acesso à região doadora. Na sinfise mandibular, seguiram-se os procedimentos técnicos descritos por TULER; NARY FILHO90 (1999), procedendo-se a incisão em mucosa labial e divulsão por planos até a exposição da superfície óssea do mento. Para a osteotomia, empregou-se serra oscilatória pneumática* após prévia demarcação da área a ser removida com brocas esféricas de aço número $1 / 2$ sob abundante irrigação com soro fisiológico. Estes cortes foram completados com o auxílio de cinzéis e martelo até a liberação do bloco ósseo desejado. Os procedimentos de

\footnotetext{
* Microdrive plus e serra oscilante 6000 osc./min., Synthes - STRATEC Medical, Suíça
} 
Tabela 1 - Caracterização dos procedimentos e pacientes incluídos nesta amostra

\begin{tabular}{|c|c|c|c|c|c|c|c|c|}
\hline $\mathbf{N} .{ }^{\circ}$ & NOME & SEXO & IDADE & ÁREA RECONSTRUÍDA & REGIÃo & $\begin{array}{c}\text { ZONA } \\
\text { DOADORA }\end{array}$ & $\begin{array}{c}\text { TIPO DE } \\
\text { ANESTESIA }\end{array}$ & $\begin{array}{c}\text { DIMENSÃO } \\
\text { APROXIMADA DO } \\
\text { BLOCO }\end{array}$ \\
\hline 1 & AMRS & Masc. & 41 & & $12-21$ & Ilíaco & Geral & $5 \times 2 \times 0,7 \mathrm{~cm}(\mathrm{EP})$ \\
\hline 2 & ARP & Masc. & 67 & & $13-16$ & Ilíaco & Geral & $7 \times 2 \mathrm{~cm}(\mathrm{ET})$ \\
\hline 3 & NOS & Fem. & 51 & & $16-26$ & Ilíaco & Geral & $7 \mathrm{x} 2 \mathrm{~cm}(\mathrm{ET})$ \\
\hline 4 & NMN & Fem. & 36 & & $16-26$ & Ilíaco & Geral & $6 \times 2 \mathrm{~cm}(\mathrm{ET})$ \\
\hline 5 & ARP & Masc. & 67 & & $24-26$ & Ilíaco & Geral & $7 \mathrm{x} 2 \mathrm{~cm}(\mathrm{ET})$ \\
\hline 6 & RAP & Masc. & 47 & & 15 & Mento & Local & $1,2 \times 0,6 \mathrm{~cm}$ \\
\hline 7 & SFC & Fem. & 28 & & $21-23$ & Mento & Local & $1,8 \times 0,7 \mathrm{~cm}$ \\
\hline 8 & JBR & Masc. & 31 & & $11-22$ & Mento & $\begin{array}{l}\text { Local + } \\
\text { Sedação }\end{array}$ & $2,5 \times 0,8 \mathrm{~cm}$ \\
\hline 9 & NATO & Fem. & 55 & & $24-26$ & Mento & Local & $1,8 \times 0,8 \mathrm{~cm}$ \\
\hline 10 & VAAZ & Fem & 40 & & $14-15$ & Mento & Local & $1,4 \times 0,8 \mathrm{~cm}$ \\
\hline
\end{tabular}


cuidados com a ferida cirúrgica incluíram irrigação abundante com soro fisiológico, sutura por planos e reinserção muscular com fios de sutura sintéticos de poliglactina 910 (Vicryl ${ }^{* *}$ ) e

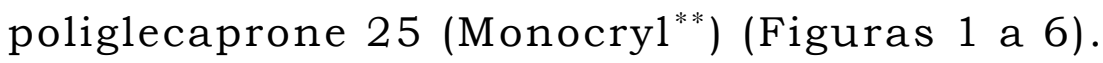

$\mathrm{Na}$ região do ílio, realizou-se incisão na pele paralela à crista iliaca anterior começando dois centímetros lateralmente à espinha iliaca, continuando 8 a 10 centímetros ao longo do tubérculo da crista.

Realizada a exposição do ílio, a porção de crista removida foi proporcional ao volume de enxerto ósseo necessário. Em reconstruções menores, somente a face interna da crista ilíaca foi removida, mantendo-se o contorno ósseo da região. Nas situações em que houve necessidade de enxertos maiores, removeu-se a crista incluindo ambas corticais.

Para todos os casos, praticou-se divulsão por planos e descolamentos periostais nas faces interna e externa do ílio. Pela incisão na linha periostal entre os músculos glúteo e abdominal, obteve-se plano de referência para descolamento medial de fossa ilíaca e lateral dos músculos glúteos. A extensão destes

\footnotetext{
** Johnson \& Johnson, São José dos Campos - Brasil
} 

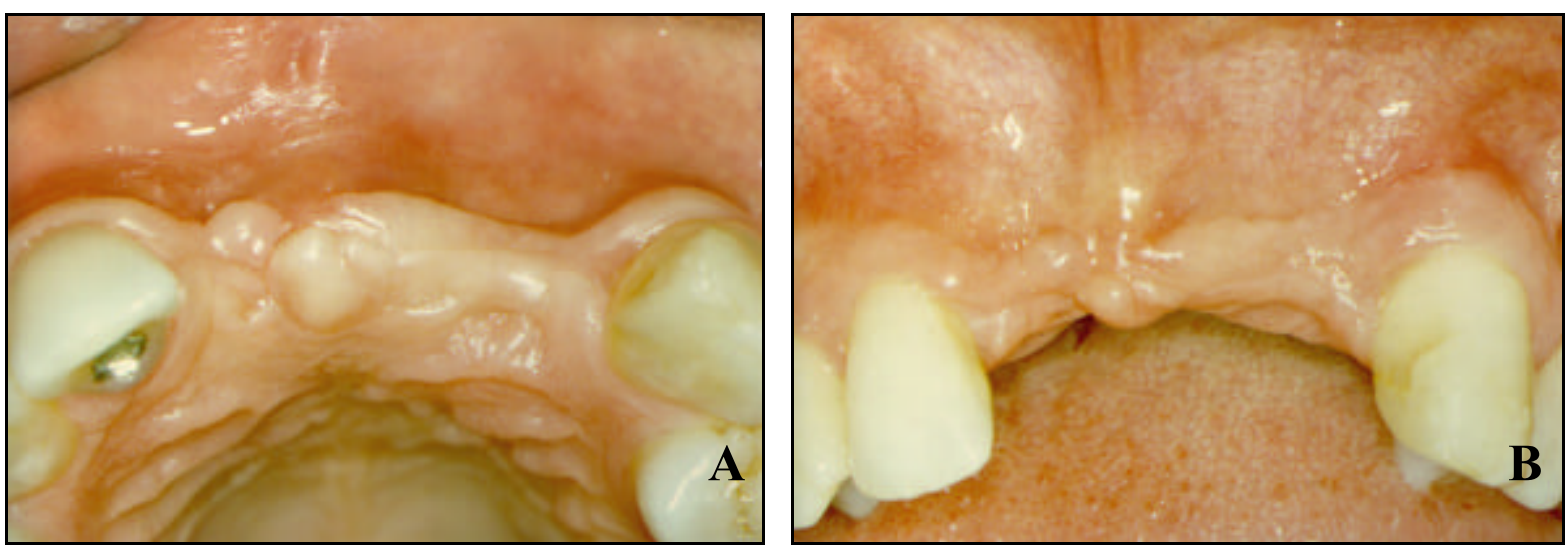

Figura 1 - Aspecto clínico da região de rebordo maxilar a ser reconstruída com enxerto de mento

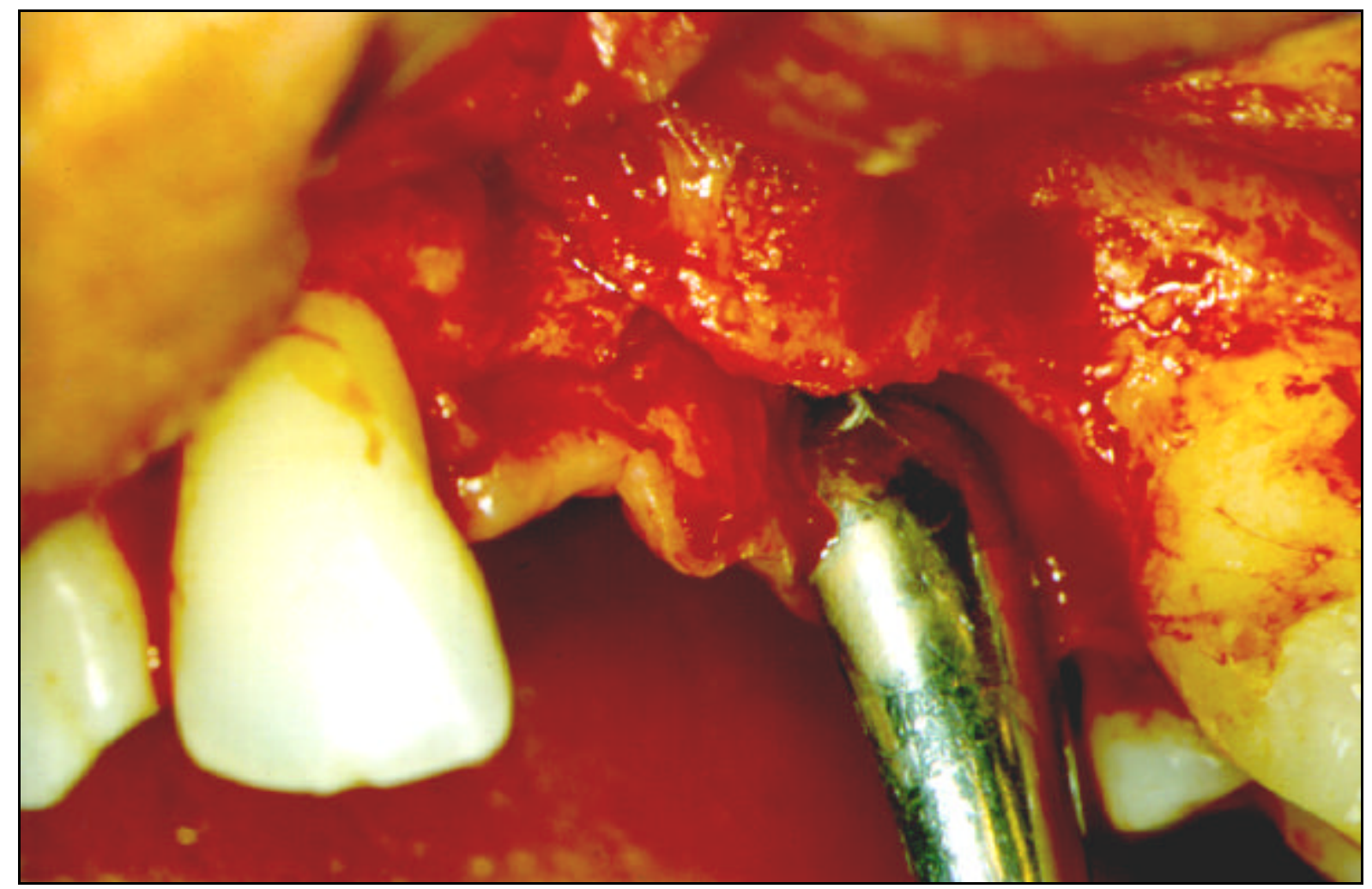

Figura 2 - Exposição do leito cirúrgico para visualização do defeito ósseo 

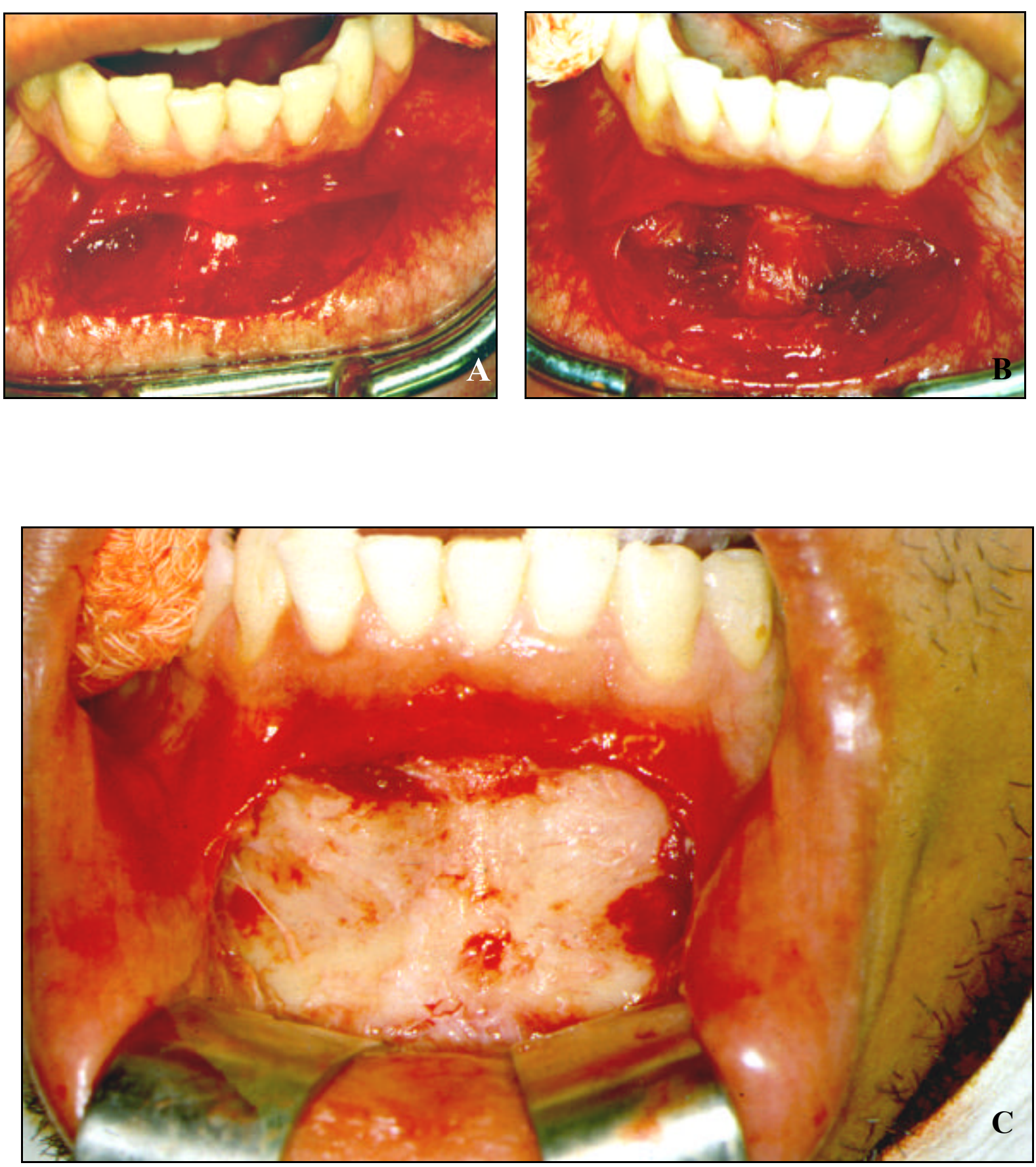

Figura 3 - Acesso à região mentoniana: A) incisão em mucosa labial; B) divulsão por planos; C) descolamento mucoperiostal 

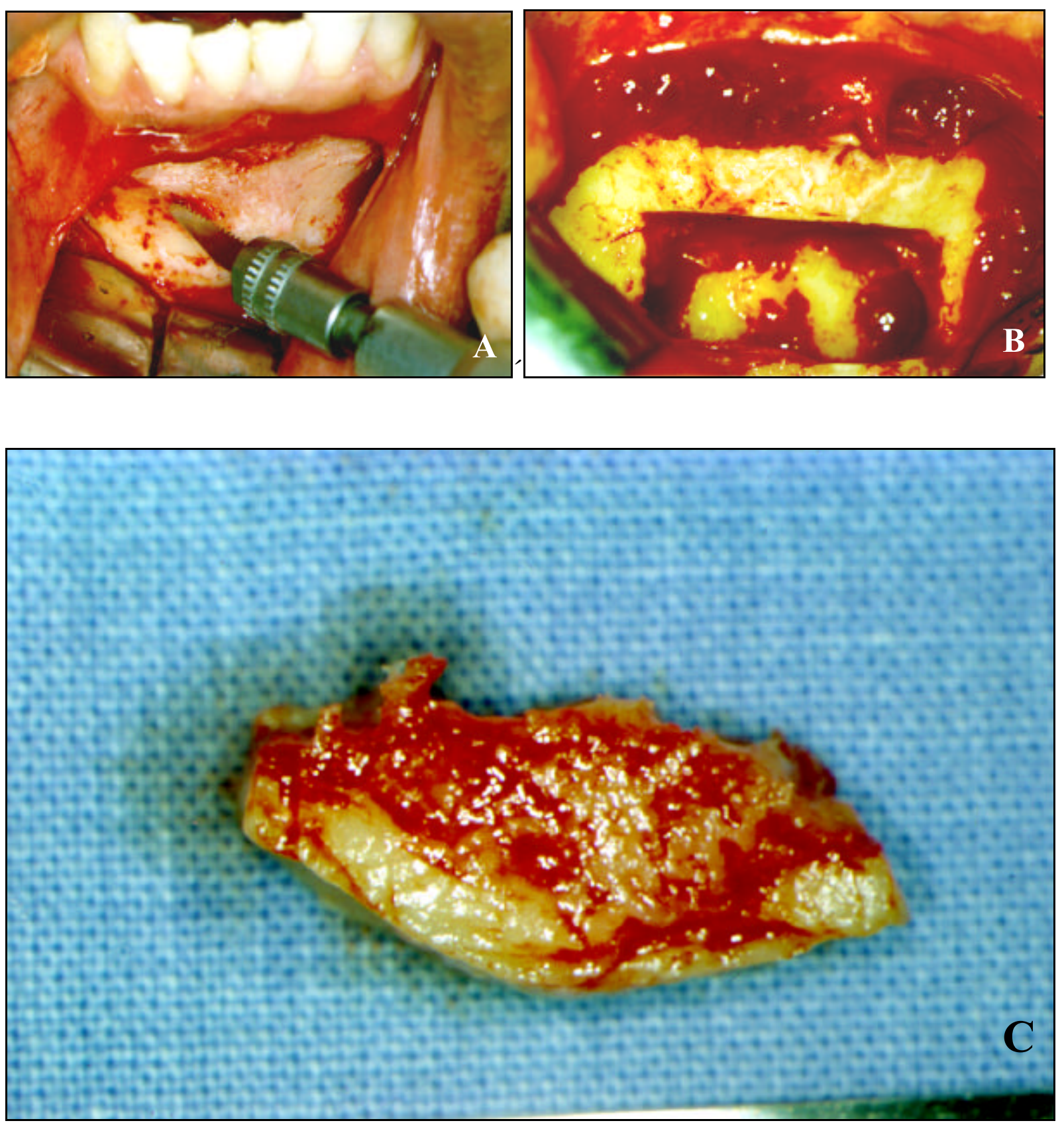

Figura 4 - Obtenção do enxerto: A) osteotomia com serra pneumática, demarcando a região óssea a ser removida; B) cavidade resultante da remoção do enxerto; C) bloco ósseo removido 


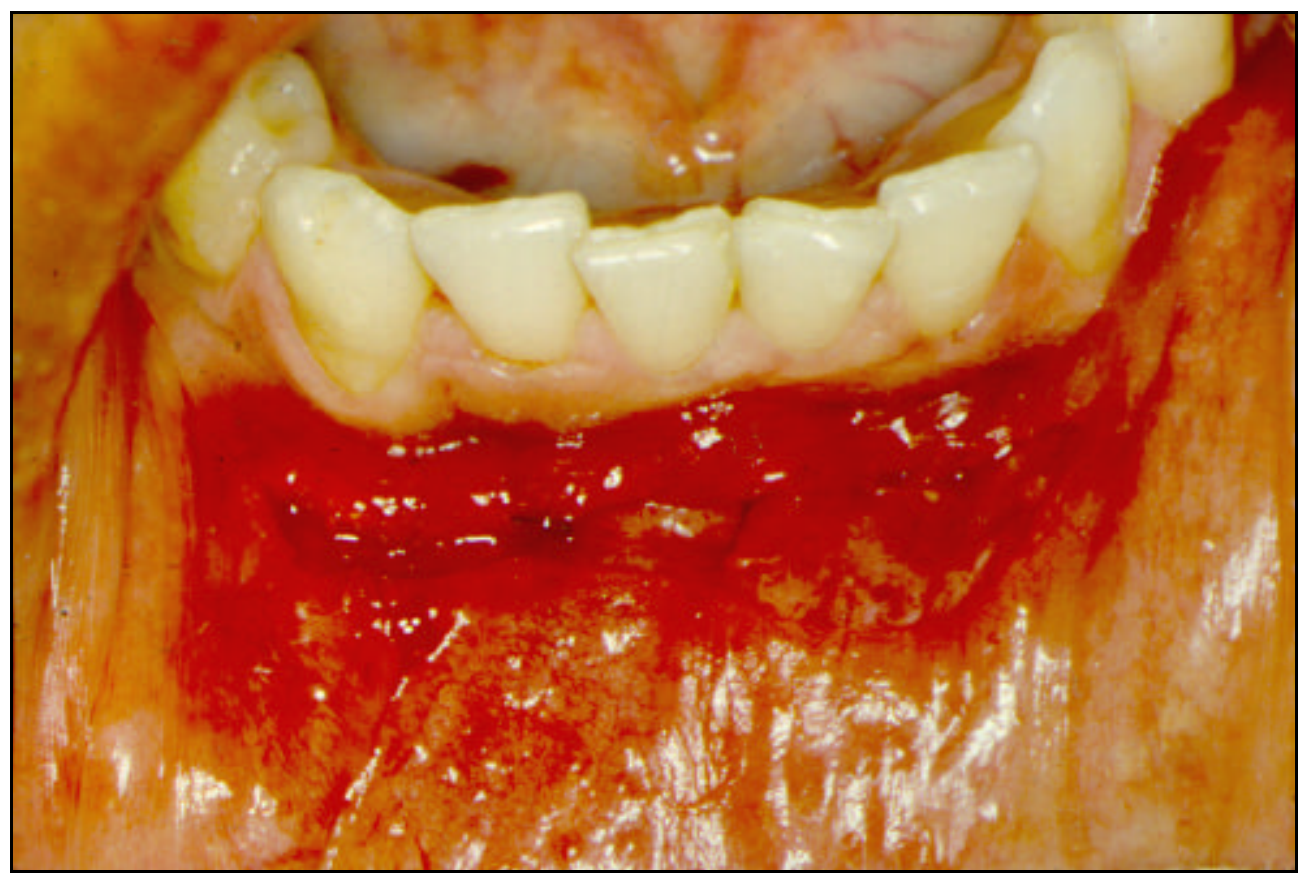

Figura 5 - Sutura da região doadora

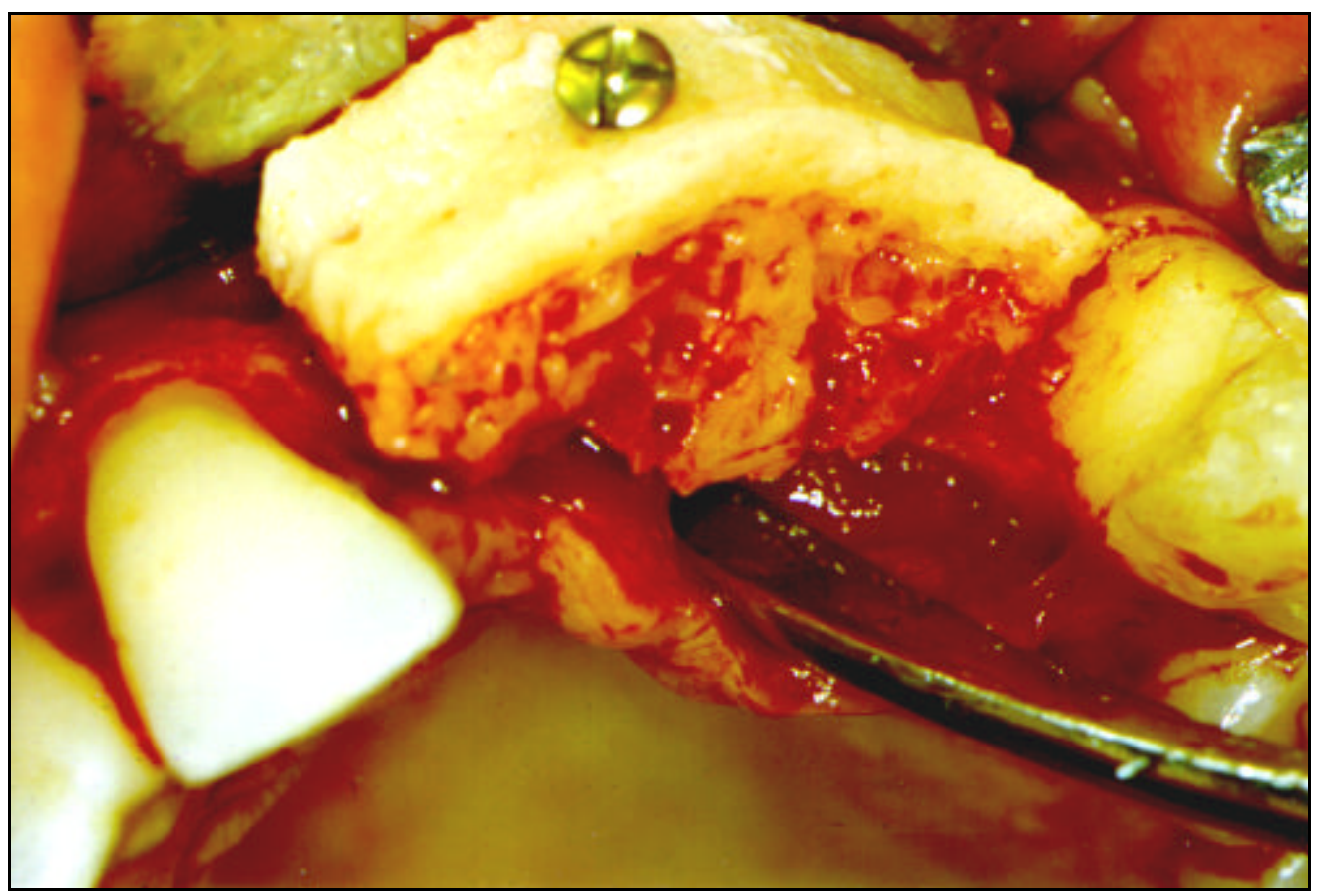

Figura 6 - Fixação do enxerto ao leito receptor com parafuso de titânio 
descolamentos variou dependendo da demanda óssea requerida. Onde pouco enxerto foi necessário, o descolamento restringiu-se ao aspecto medial da crista para minimizar danos pósoperatórios. Este descolamento não ultrapassou, em nenhum caso, $8 \mathrm{~cm}$ em direção aos planos profundos. A obtenção do fragmento requereu o emprego de serra pneumática, cinzéis e formões com martelo, sempre sob contínua refrigeração com soro fisiológico. Na maioria dos casos que integraram este estudo, pela grande demanda de enxerto, praticou-se a remoção da crista incluindo as duas corticais. As suturas foram realizadas por planos com fios absorvíveis, poliglactina 910 (Vicryl), sendo instalado dreno ativo***, mantido nas primeiras 24-48 horas. Os planos superficiais receberam sutura com fio de mononylon 4-0 em pontos isolados (Figuras 7 a 11). Em apenas um dos pacientes, optou-se pela remoção do fragmento da porção medial preservando parte da espessura de crista e sua face lateral.

Removidos os blocos da região doadora, estes foram mantidos em solução de Ringer lactato de sódio a $5 \%$ ou solução salina a $0,9 \% 48,49,84$. Em seguida, realizou-se a adaptação e fixação do enxerto ao leito receptor empregando-se alveolótomo, serra pneumática e brocas de desgaste multilaminadas. Procurouse manter a área cortical do enxerto sobre o defeito para facilitar

**** Bio - Suc, Bio Mecânica - São Paulo, Brasil 

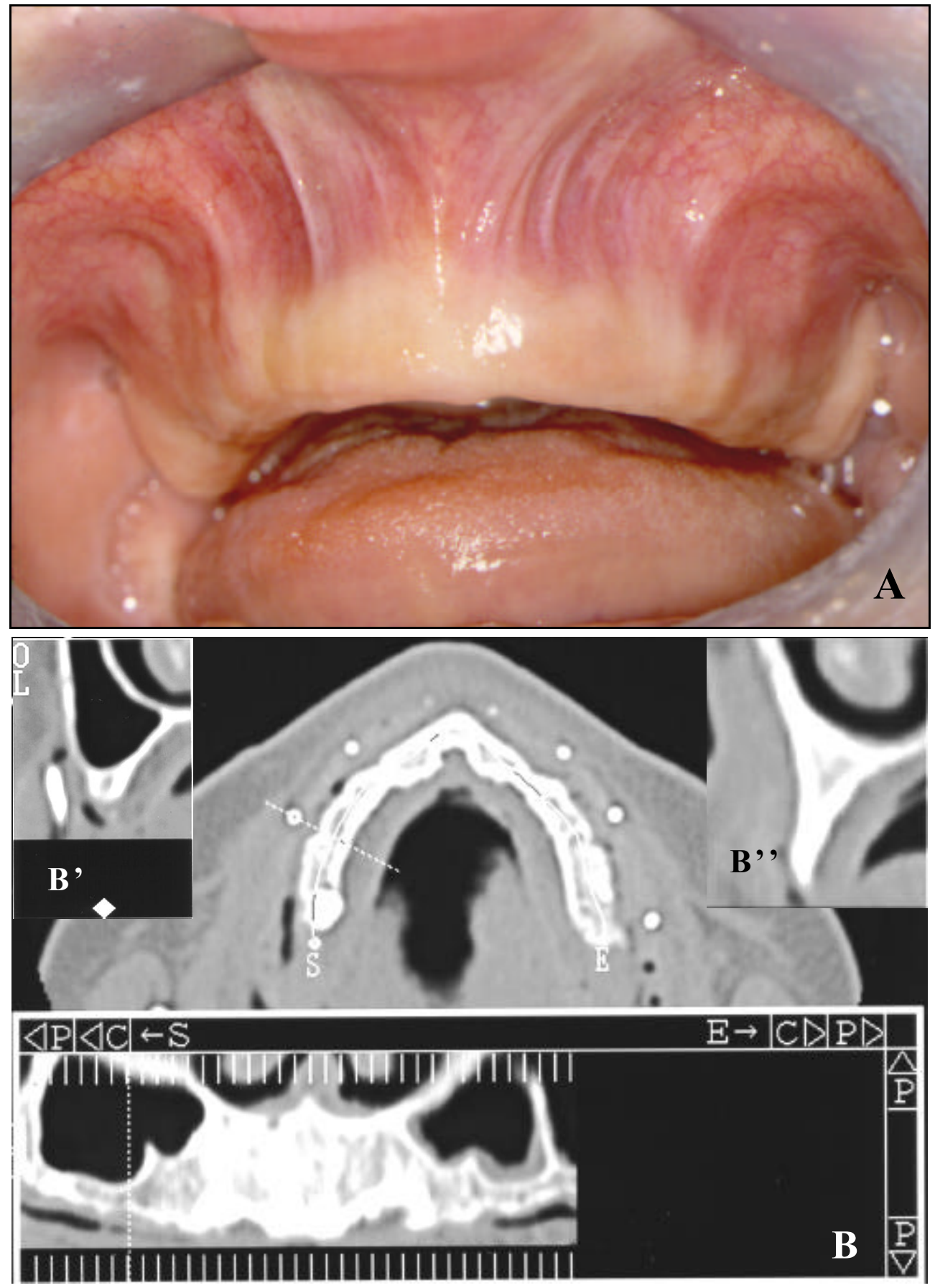

Figura 7 - A) Aspecto clínico da região de rebordo maxilar a ser reconstruido com enxerto de crista ilíaca; B) Imagem tomográfica desta mesma região demonstrando a deficiência óssea em altura, pela extensão alveolar do seio maxilar (B') e espessura (B'') 


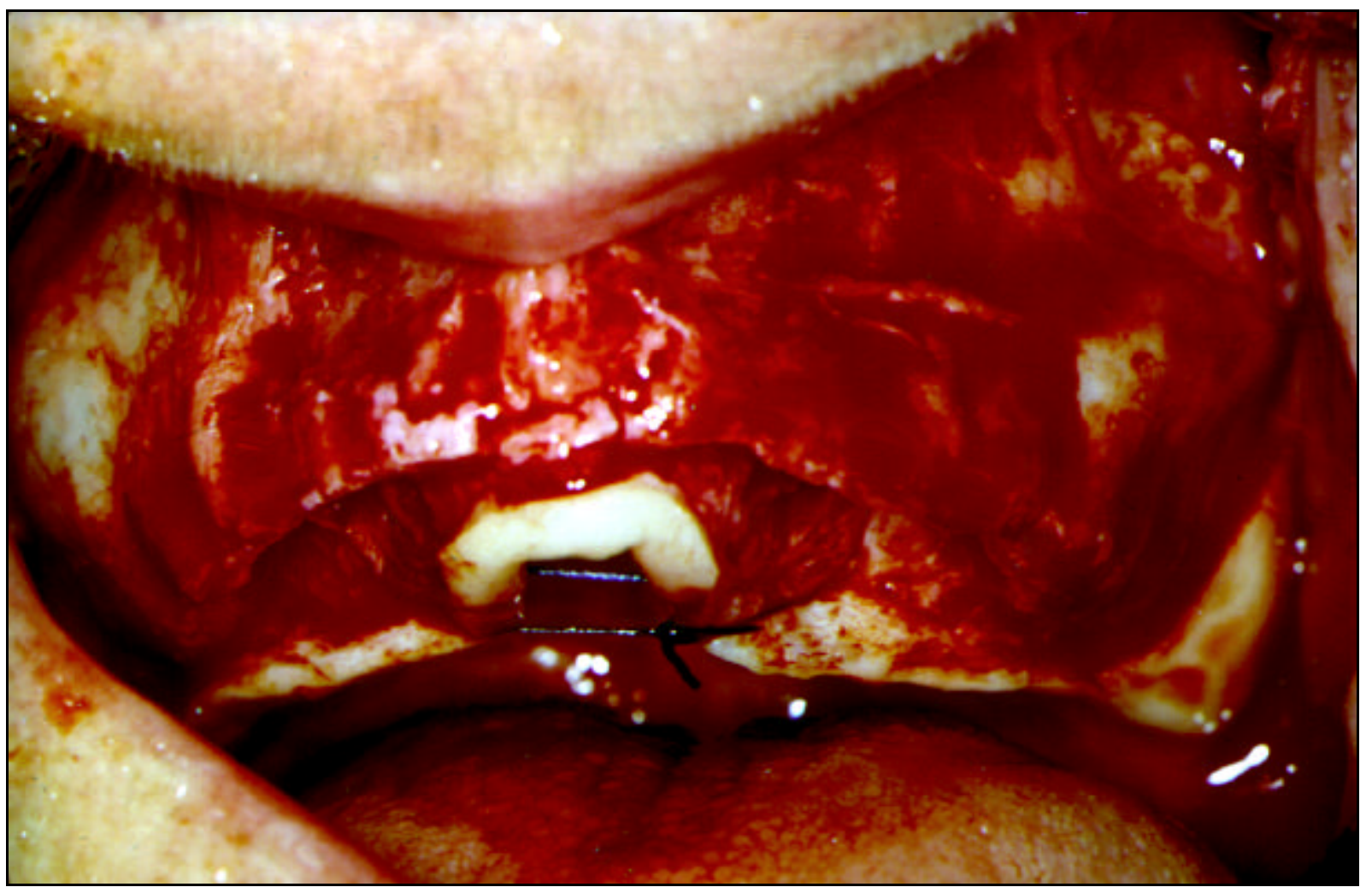

Figura 8 - Exposição do leito cirúrgico para visualização do defeito ósseo a ser reconstruído
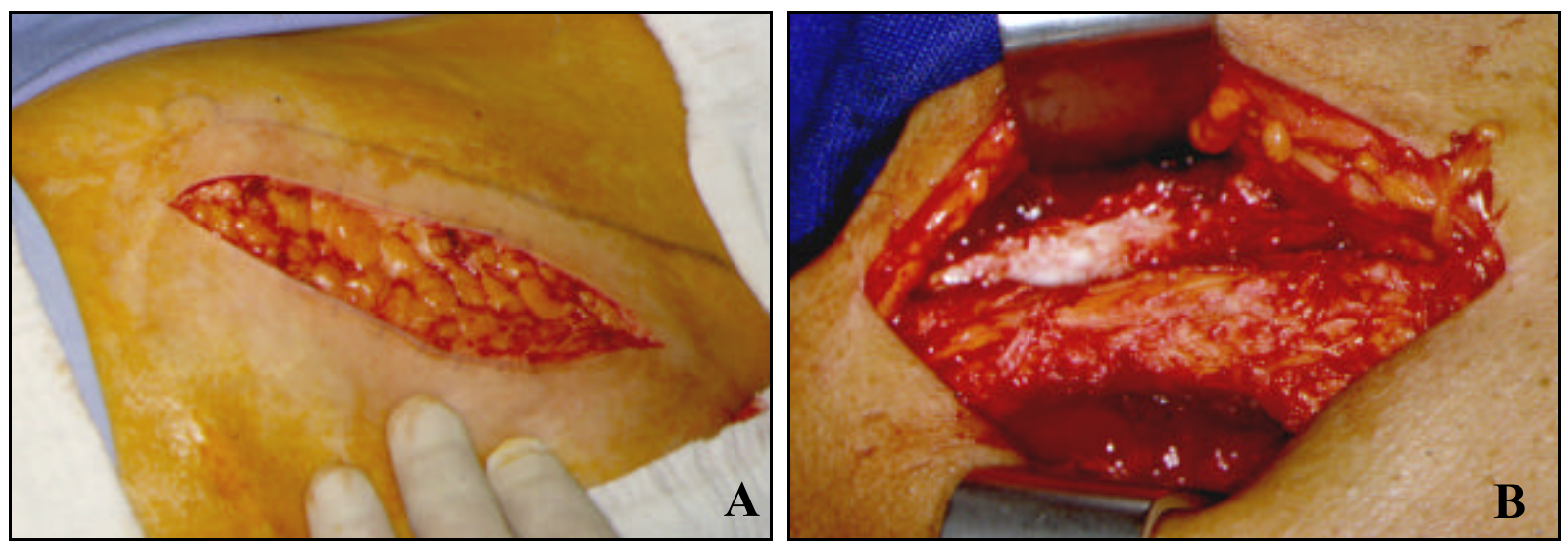

Figura 9 - A) Incisão de pele paralela a crista ilíaca com 8,0cm de extensão; B) Descolamento e exposição da crista do ileo 

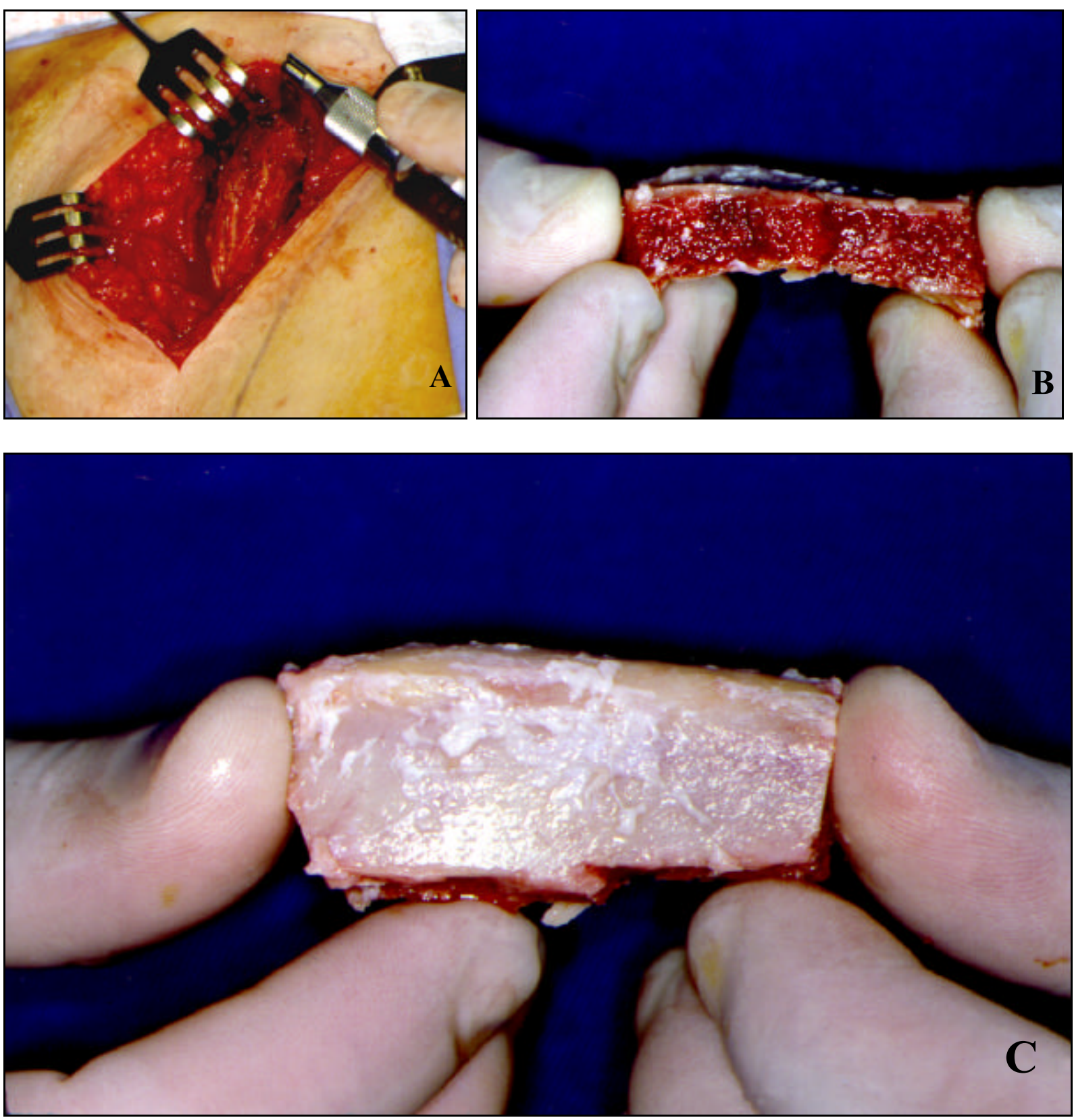

Figura 10 - A) Osteotomia com serra pneumática para remoção do bloco ósseo; B-C) Fragmento ósseo obtido de espessura bicortical 

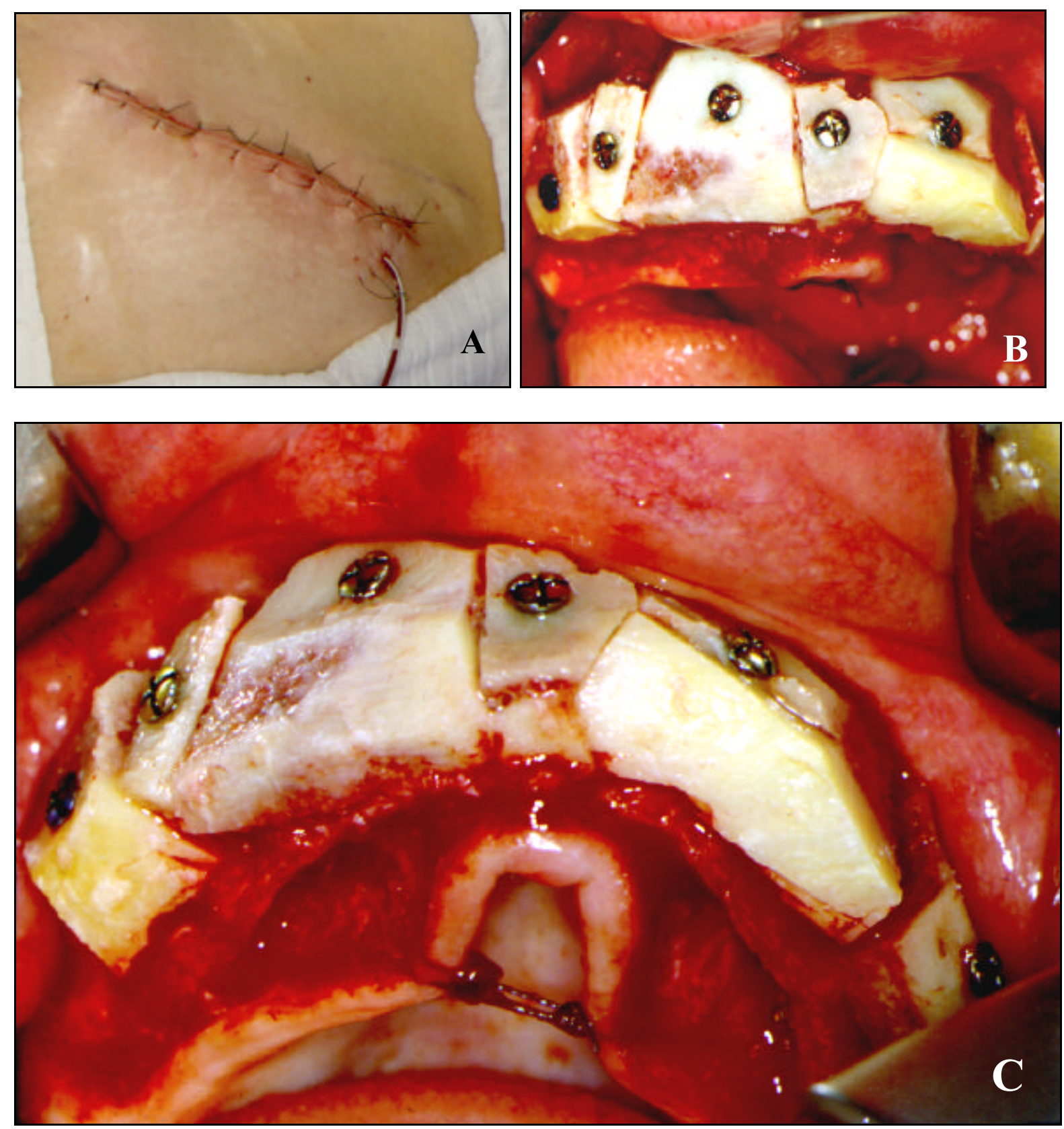

Figura 11 - A) Sutura da região doadora e instalação do dreno; B-C) Adaptação e fixação dos blocos de enxerto de crista iliaca com parafusos de titânio 
e dar maior efetividade à fixação. Com os blocos, devolveu-se a anatomia da região, incluindo uma sobre correção, prevendo-se o fenômeno de reabsorção óssea pós-operatória. A fixação dos blocos foi realizada com parafusos bicorticais de titânio de $2,0 \mathrm{~mm}$ de diâmetro com comprimentos variáveis ${ }^{* * *}$. Os espaços vazios, onde não se obteve contato do enxerto com o leito receptor, foram preenchidos com fragmentos ósseos medulares resultantes do preparo do bloco. Nenhum cuidado foi observado com relação à ativação do leito receptor com perfurações 55 . Somente os blocos maiores e provenientes da região do ilio foram perfurados aleatoriamente com brocas cilindricas de $1,1 \mathrm{~mm}$ de diâmetro e $8 \mathrm{~mm}$ de profundidade.

A cobertura mucosa do enxerto foi conseguida a expensas de grande divulsão submucosa das regiões vizinhas, vestíbulo, mucosa labial com preservação do periósteo. As suturas promoveram não somente a aproximação das bordas como também o aumento de contato de suas faces cruentas.

Nos pacientes submetidos ’a reconstrução com ilio, além da medicação empregada de rotina em procedimentos sob anestesia geral, empregou-se cobertura antibiótica com cefalotina 4g/dia, por sete dias, antiinflamatórios não hormonais, 
diclofenaco sódico $225 \mathrm{mg} / \mathrm{dia}$, por dois dias e analgésicos, dipirona $4 \mathrm{~g} /$ dia durante dois dias.

Os pacientes, após os procedimentos cirúrgicos, seguiram as orientações básicas para este tipo de tratamento, evitando-se, em especial, o trauma e o uso de próteses sobre o local por período mínimo de 15 dias. Já os que receberam enxerto da área mentoniana, fizeram uso de $2 \mathrm{~g} /$ dia de cefalexina, durante sete dias, além de analgésico, 2 g/dia de dipirona por dois dias. Não empregou-se, nestes casos, antiinflamatório.

Decorrido período de quatro meses da colocação dos enxertos e com o devido consentimento dos pacientes, simultaneamente à inserção dos implantes, procedeu-se uma biópsia incisional da região enxertada com auxílio de brocas trefina de $2,6 \mathrm{~mm}$ de diâmetro interno ${ }^{* * * * *}$. A broca atuou em direção transversal ao rebordo, no sentido vestibulolingual sob constante refrigeração com soro fisiológico, obtendo-se material representativo do rebordo alveolar e do enxerto (Figura 12). Atenção foi dada para se eleger áreas onde praticar-se-ia a plastia do rebordo com intuito de reduzir o volume ósseo desnecessário, evitando-se também os locais onde os implantes seriam posicionados. 
Desta forma, obtiveram-se amostras de tecido ósseo para avaliação, cinco espécimes de rebordos reconstruídos com enxertos oriundos da crista iliaca e cinco espécimes correspondentes à regiões onde foram aplicados enxertos ósseos autógenos oriundos do mento (Figura 13).

\subsection{Preparação das amostras}

Os espécimes foram colocados em frascos de vidro individuais, devidamente identificados, contendo formaldeído a $10 \%$ por um período mínimo de 48 horas. Em seguida, foram submetidos ao processo de desmineralização em solução de ácido etilenodiaminotetracético (EDTA) 10\%, tamponado com pH 7,0, com trocas realizadas duas vezes por semana. Após quatro semanas, em média, considerou-se finalizado o processo de desmineralização, quando o tecido ósseo apresentava-se com consistência borrachóide, sem resistência ao corte por lâmina de microtomia. As peças foram lavadas em água corrente, desidratadas em álcool, diafanizadas em xilol e incluídas em parafina.

Obtiveram-se cortes seriados de $5 \mu \mathrm{m}$ de espessura 


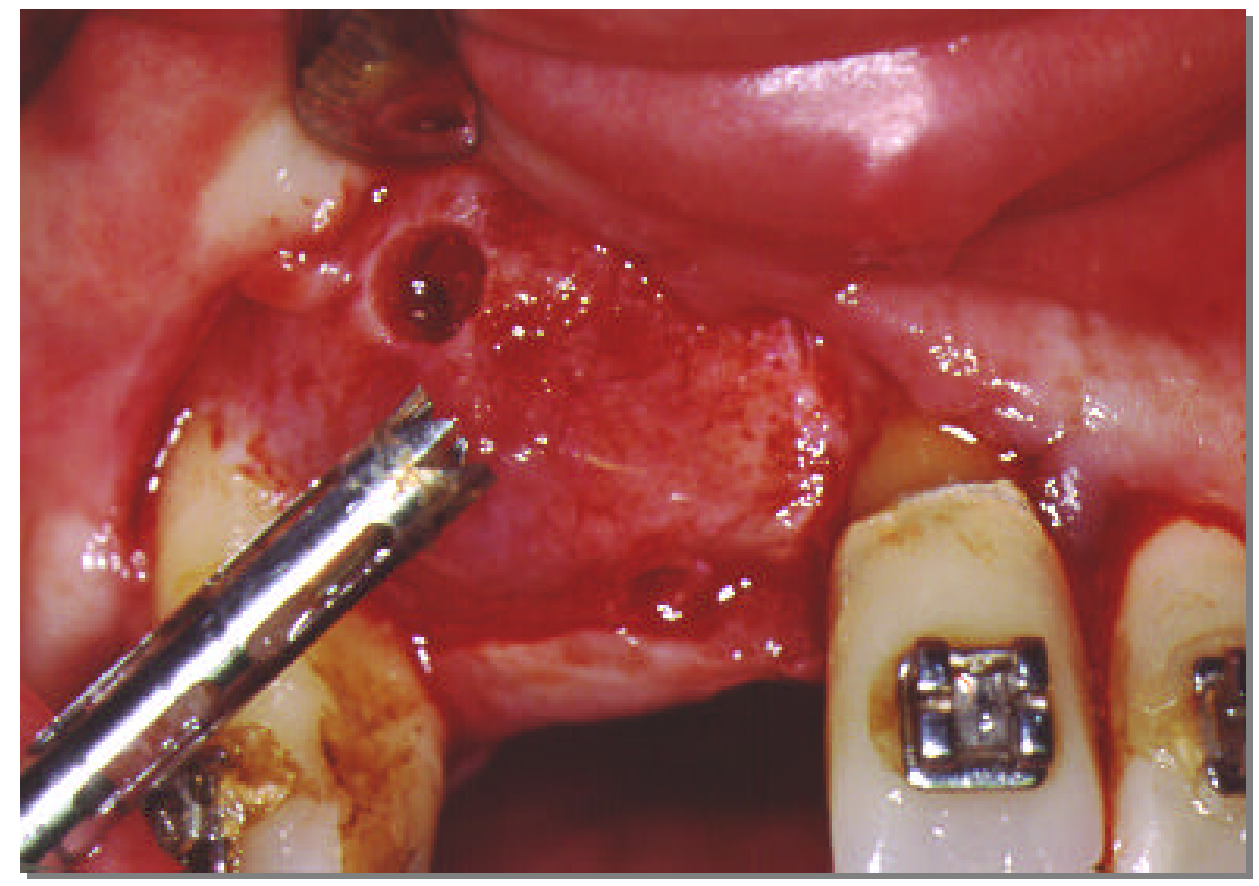

Figura 12 - Método de obtenção da amostra, empregando broca trefina sobre o rebordo reconstruído no período de quatro meses após a realização do enxerto

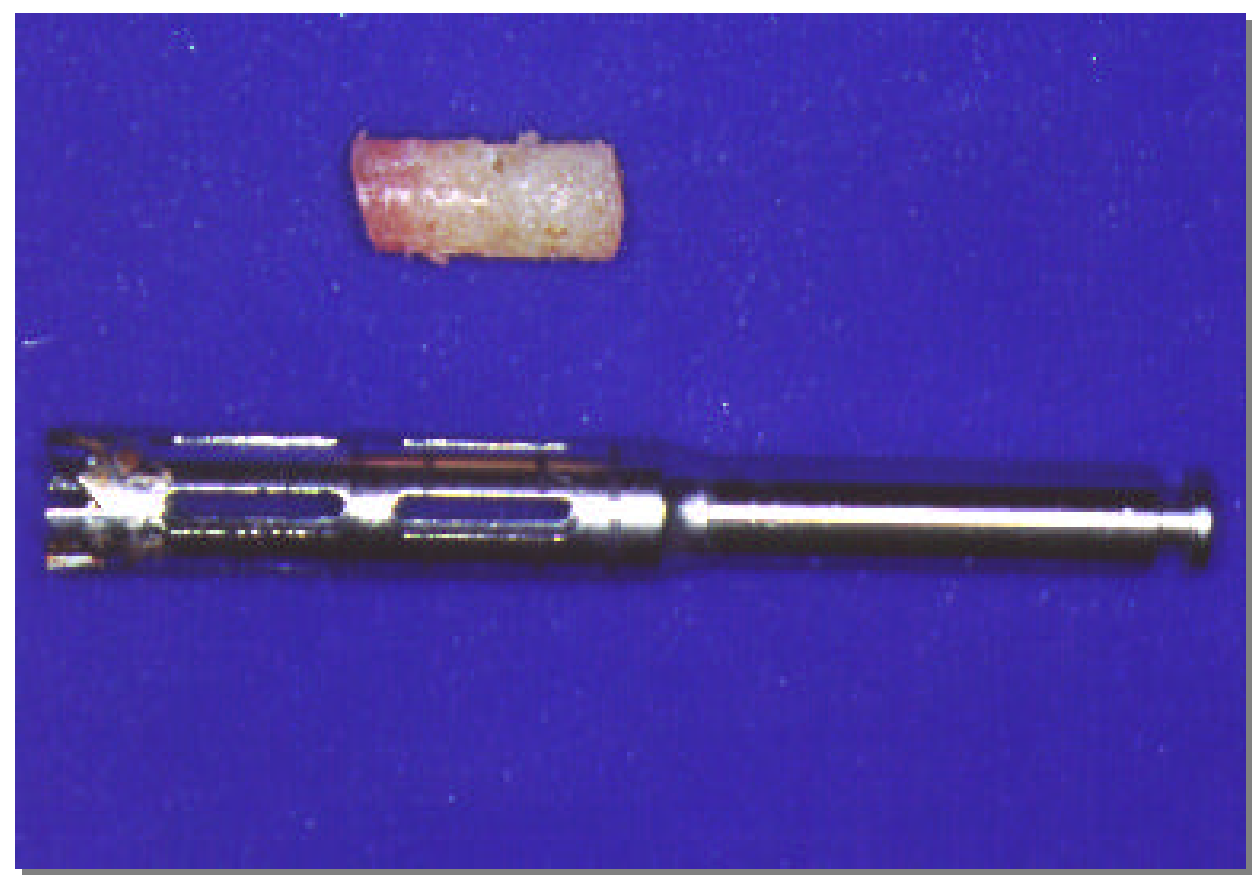

Figura 13 - Aspecto macroscópico do espécime obtido 
Obtiveram-se cortes seriados de $5 \mu \mathrm{m}$ de espessura de cada bloco utilizando-se micrótomo rotatório elétrico Leica RM. Empregou-se para a análise, os cortes centrais do espécime, onde a maior espessura seria representada, correspondendo ao diâmetro máximo do cilindro ósseo. As tiras foram colocadas em banho-maria, de onde foram retiradas e imediatamente dispostas por sobre a lâmina com albumina. As lâminas seguiram para a estufa e posteriormente para a desparafinização.

Os métodos de coloração empregados foram o da Hematoxilina-Eosina de Harris (HE) e Tricrômico de Mallory preconizados e registrados nos protocolos técnicos da Disciplina de Histologia do Curso de Odontologia da Universidade do Sagrado Coração.

Para a obtenção de dados compatíveis com a proposta do estudo, foram empregadas duas análises deste material. Inicialmente, procedeu-se uma análise microscópica descritiva das lâminas, buscando estabelecer a condição de reparo destas regiões. Posteriormente, para levantar dados sobre a qualidade óssea obtida com os procedimentos de enxertia, efetuou-se uma análise microscópica dos traçados das áreas de matriz óssea mineralizadas. Estas análises são descritas a seguir. 


\subsection{Análise microscópica descritiva}

A leitura das lâminas foi realizada com auxílio de microscópio Olympus CBA binocular, analisando-se a presença ou ausência dos fenômenos de manutenção e ou reabsorção do osso implantado, de neoformação óssea cortical e trabecular, formação de tecido medular e sua organização, fibrosamento medular, neoformação do endósteo, além do tipo e intensidade de infiltrado inflamatório.

Os dados obtidos a partir da identificação dos critérios morfológicos microscópicos foram registrados em quadros apropriados, de acordo com sua ocorrência em cada espécime analisado, permitindo posterior descrição dos fenômenos e análise comparativa. Os fenômenos morfológicos observados em alguns espécimes foram registrados pelas fotomicrografias, ilustrando a descrição microscópica. Estas foram obtidas a partir de aparelho Zeiss da Disciplina de Patologia da Faculdade de

Odontologia de Bauru (FOB-USP) utilizando-se filme Elite GoldKodak, ISO 100. 


\subsection{Análise dos traçados das áreas de matriz óssea mineralizada}

Por meio de projetor macronúcleo da marca BIOTEC, fez-se a projeção das lâminas, sobre um anteparo de madeira recoberto por uma folha de papel branco. Nas projeções, foram utilizadas objetiva de $5 \mathrm{x}$ e ocular de $5 \mathrm{x}$. A imagem projetada distou $43,5 \mathrm{~cm}$ da fonte, representada por um cristal trifacetado. Este método foi inicialmente preconizado por PEREIRA62, no ano de 1995.

$\mathrm{Na}$ imagem projetada, convencionou-se a eleição de três regiões assim definidas:

Área $A$ - porção superficial do espécime, representando a área cortical externa do enxerto.

Área $B$ - porção média do espécime, representando área medular do enxerto.

Área $C$ - porção alveolar do espécime, representando o rebordo, ou o local de transição entre o rebordo e o enxerto.

Para as medidas das áreas relacionadas a estas regiões, foram utilizados espaços padronizados (template) de $11 \mathrm{~cm} \mathrm{x} 8 \mathrm{~cm}$ colocados sobre os traçados delimitando-se a região a ser mensurada. Todas as superfícies ósseas presentes neste espaço foram delineadas, como pode ser visto na Figura 14, a seguir. 

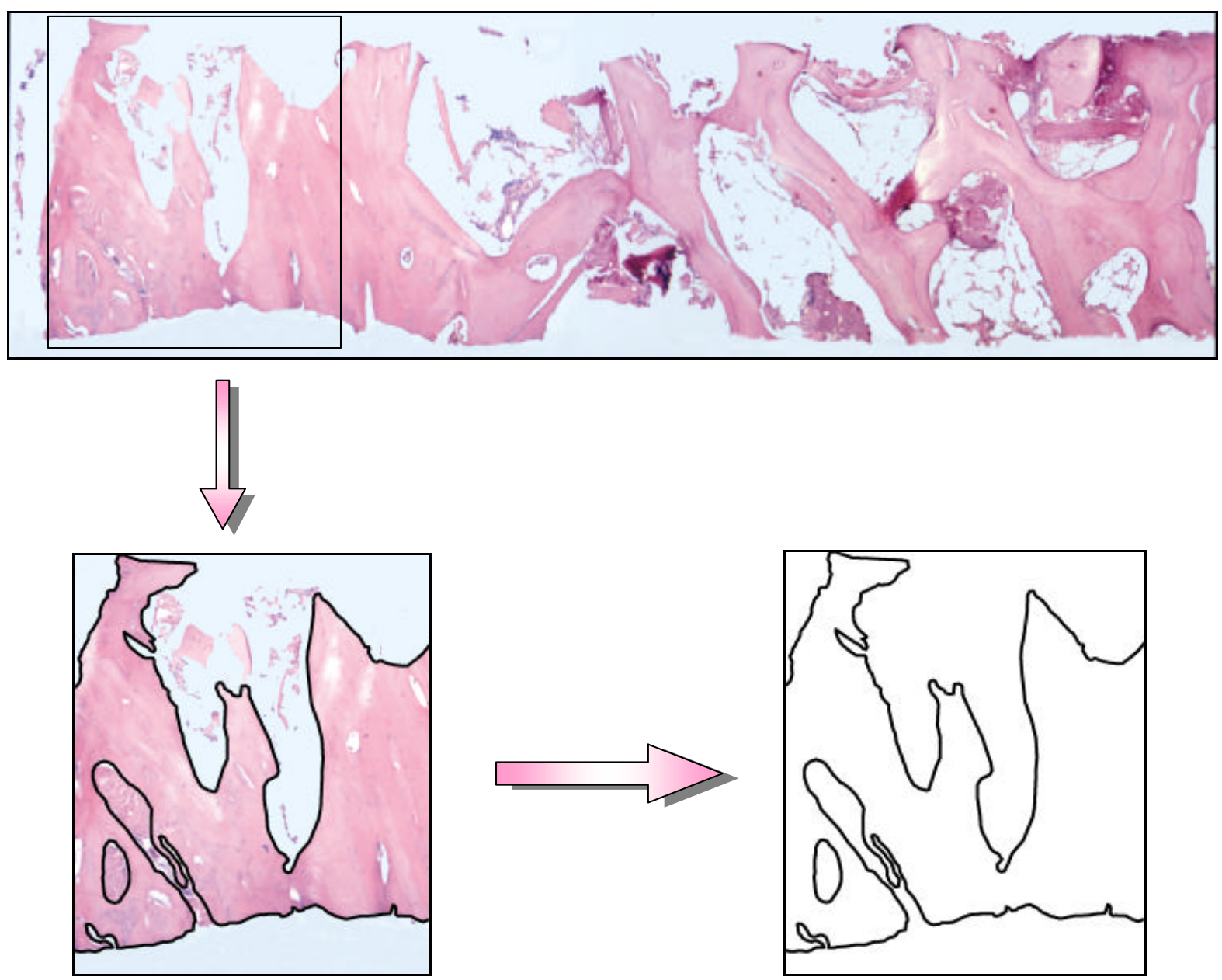

Figura 14 - Exemplo do traçado de área de matriz óssea mineralizada

Após terminados os traçados propostos, fez-se a mensuração de seus contornos em uma mesa digitalizadora Digigraph Renoir, pertencente ao Departamento de Morfologia da Faculdade de Odontologia de Bauru, da Universidade de São Paulo, acoplada a um programa de computador para cálculo de áreas, desenvolvido pelo Hospital de Reabilitação de Anomalias Craniofaciais - USP. As áreas correspondentes à medula óssea foram subtraídas, considerando-se apenas as superfícies das 
trabéculas e corticais ósseas, bem como os sistemas de Havers, cujas medidas foram feitas com repetições triplas, pelo mesmo operador. Obteve-se, assim, uma média de cada área individual com seu respectivo desvio padrão.

Os dados obtidos dos traçados das áreas mineralizadas dos diferentes tipos de enxerto foram confrontadas entre si pela análise de variância, teste $F$ e teste de Tukey, em nível de significância de $5 \%$.

\subsection{Observações clínicas}

A fim de correlacionar os resultados obtidos das análises microscópicas, procurou-se associar os achados clínicos mais representativos destes casos.

Buscou-se relacionar no capítulo de resultados, além dos achados de interesse para a proposição do estudo, as características do local de enxertia no momento da obtenção das amostras e da instalação dos implantes. Relacionou-se, nestas observações, a efetividade do tratamento, ou seja, a verificação de qualidade e quantidade óssea e os procedimentos de inserção dos 
implantes de titânio. Da mesma forma, levantou-se o estadiamento destes casos na data de conclusão deste estudo, a fim de se observar o grau de sucesso, ainda que provisório, dos tratamentos realizados. 


\section{RESULTADOS}

A apresentação dos resultados, com a finalidade de facilitar a compreensão, seguirá a ordem de análises citada no capítulo anterior.

\subsection{Análise microscópica descritiva}

Os resultados serão apresentados descrevendo-se os aspectos microscópicos encontrados nos dois grupos experimentais. Registrou-se cada fenômeno morfológico observado nos dois grupos em quadro previamente elaborado para esta finalidade (Figura 15). A partir deste, procedeu-se a análise microscópica descritiva dos mesmos.

\subsubsection{Espécimes referentes às biópsias realizadas em região de enxerto de crista ilíaca}

$\mathrm{Na}$ análise microscópica, observou-se tecido ósseo constituido por esparsas e delgadas trabéculas ósseas, não viáveis em sua maioria (Figura 16 A). Em associação, trabéculas 
ósseas neoformadas, caracterizadas por sua desorganização tecidual e pelo grande número de osteócitos, foram observadas. Nas superfícies das trabéculas, notou-se a presença de discreta camada de células osteoblásticas. Áreas irregulares e carcomidas, associadas à presença de células ora multinucleares, ora mononucleares, foram visualizadas (Figura 16 B, C e D). Nitidas linhas basofílicas de reversão, regulares e irregulares, eram mais evidentes nas áreas de neoformação óssea (Figura 17 A e B). Medula óssea adiposa foi predominantemente encontrada nos espécimes analisados (Figura $17 \mathrm{C}$ e D). Tecido conjuntivo fibroso densamente colagenizado, ricamente vascularizado com eventuais e discretos focos de infiltrado inflamatório mononuclear também foi observado (Figura 18 A e B).

No osso cortical, verificou-se a presença de amplos sistemas de Havers ora regulares, ora irregulares, evidenciando, em algumas áreas, preenchimento por tecido ósseo neoformado, denunciando o processo de renovação óssea (Figura 18 C e D).

\subsubsection{Espécimes referentes às biópsias realizadas em região de} enxerto de mento 
$\mathrm{Na}$ análise microscópica, observou-se tecido ósseo constituido por espessas trabéculas ósseas, apresentando numerosas lacunas contendo osteócitos em seu interior, caracterizando-se como viáveis, morfologicamente (Figura 19 A e B). Foi verificada a presença de trabéculas ósseas não viáveis, estando estas ora isoladas, ora em justaposição às trabéculas viáveis. Nos fragmentos viáveis, nítidas linhas de reversão ora irregulares, ora regulares foram observadas em áreas de tecido ósseo primário, indicando fenômeno de neoformação óssea (Figura 19 B). Revestindo as superfícies trabeculares, uma regular camada osteoblástica pôde ser notada; nos espécimes onde a neoformação óssea era pronunciada, a camada osteoblástica apresentava-se mais evidente (Figura 19 C e D). Caracterizando, ainda, esta neoformação, puderam ser identificadas nítidas áreas de tecido ósseo primário, ricamente celularizado e justaposto ao osso lamelar (Figura 20 A e B). Preenchendo os espaços medulares, encontrava-se tecido adiposo, evidenciando-se em alguns espécimes, a presença de tecido hematopoiético associado. Em outros, tecido conjuntivo fibroso apresentando discreta infiltração por leucócitos mononucleares foi visualizado preenchendo os espaços medulares. Independentemente do tipo de medula presente, a vascularização dos tecidos era intensa (Figura $21 \mathrm{~A}, \mathrm{~B}$ e C). 
Nas porções referentes ao osso cortical, notou-se a presença de nitidos sistemas de Havers ora regulares, ora irregulares, cujas superfícies apresentavam-se discretamente carcomidas. Nestas áreas, tecido ósseo neoformado eventualmente foi encontrado. 


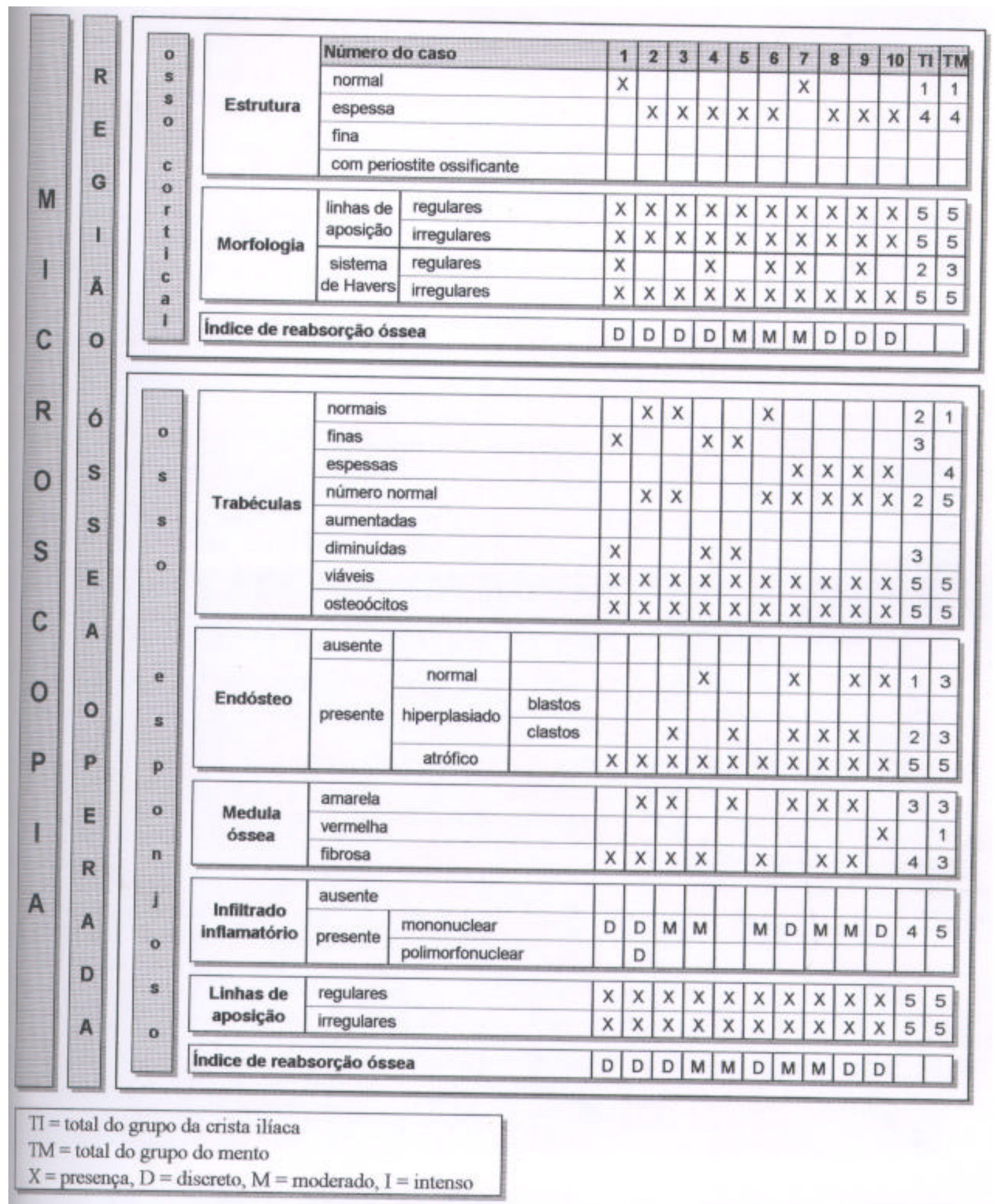

Figura 15 - Distribuição dos eventos microscópicos característicos observados nos grupos de enxertos de crista ilíaca e mento referentes às porções cortical e esponjosa 


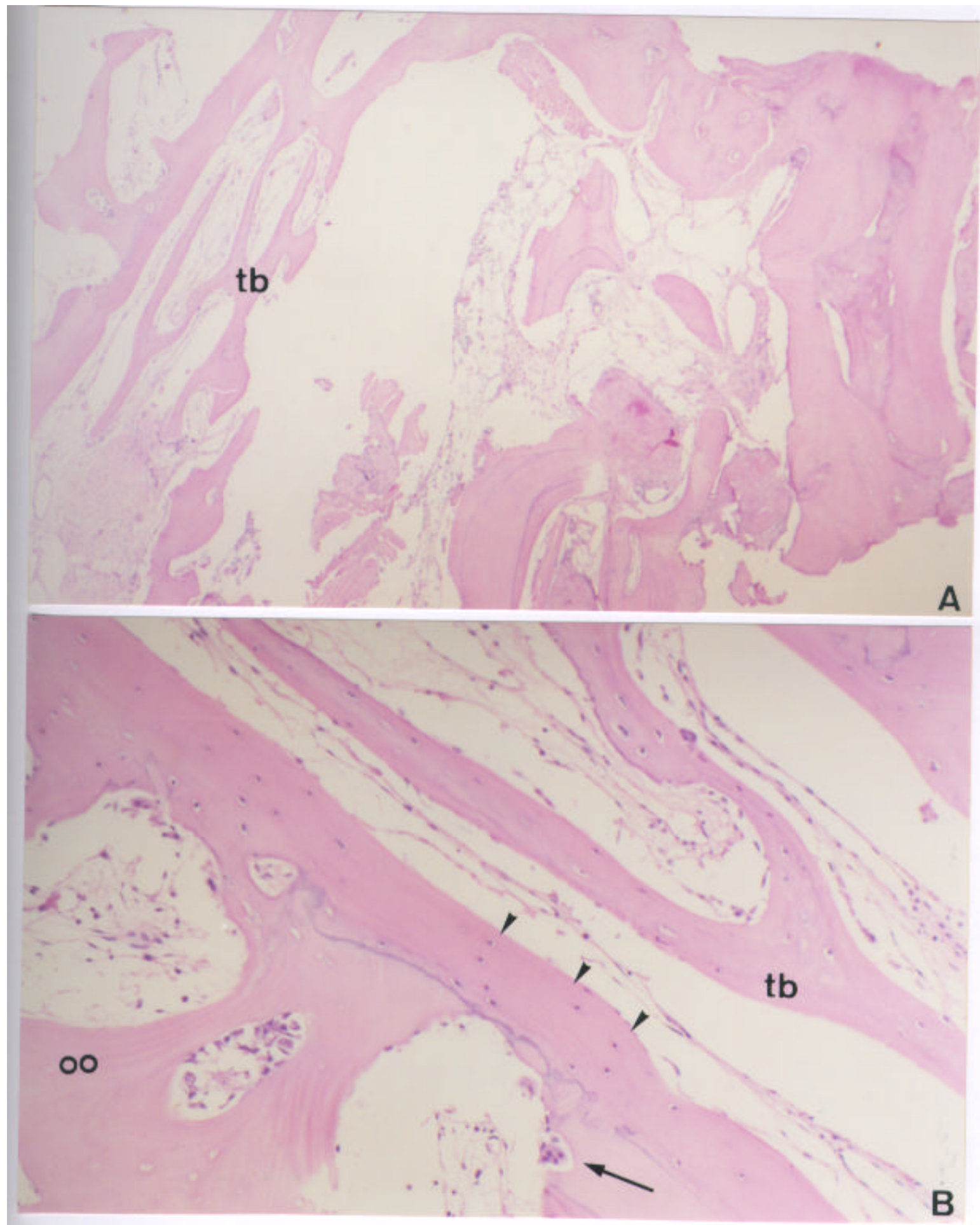

Figura 16 - Enxerto ósseo de crista ilíaca no qual se observam, na porção esponjosa do espécime, delgadas trabéculas ósseas (tb). Notam-se áreas originais sendo reabsorvidas (setas) e áreas de neoformação 

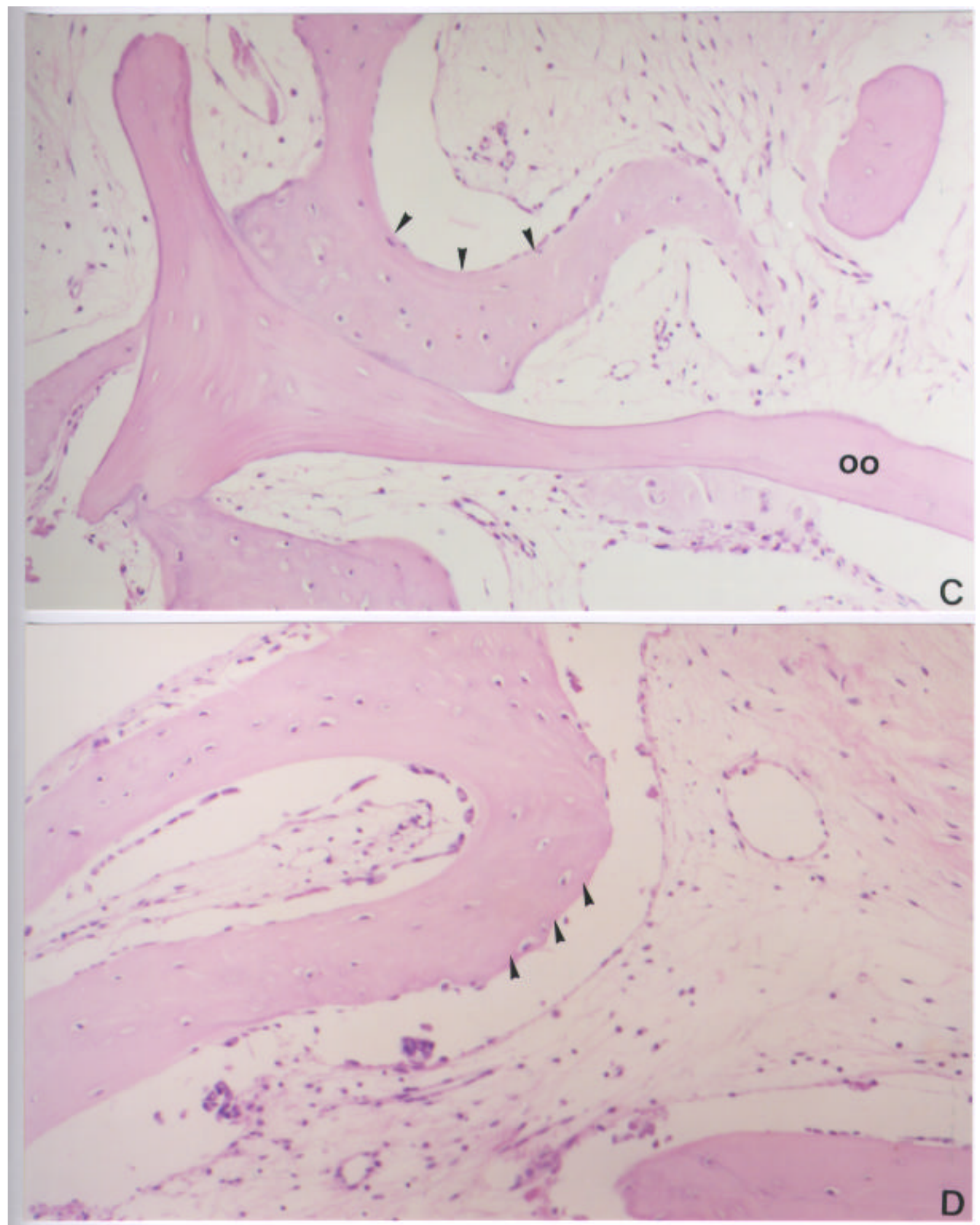

...osteogênica associadas (setas menores) à superfície do osso original (oo) e aos novos espaços medulares, estabelecendo um novo trabeculado (tb). (Coloração H.E.; aumento original: $A=16 x$; $B, C$ e $D=40 x)$ 

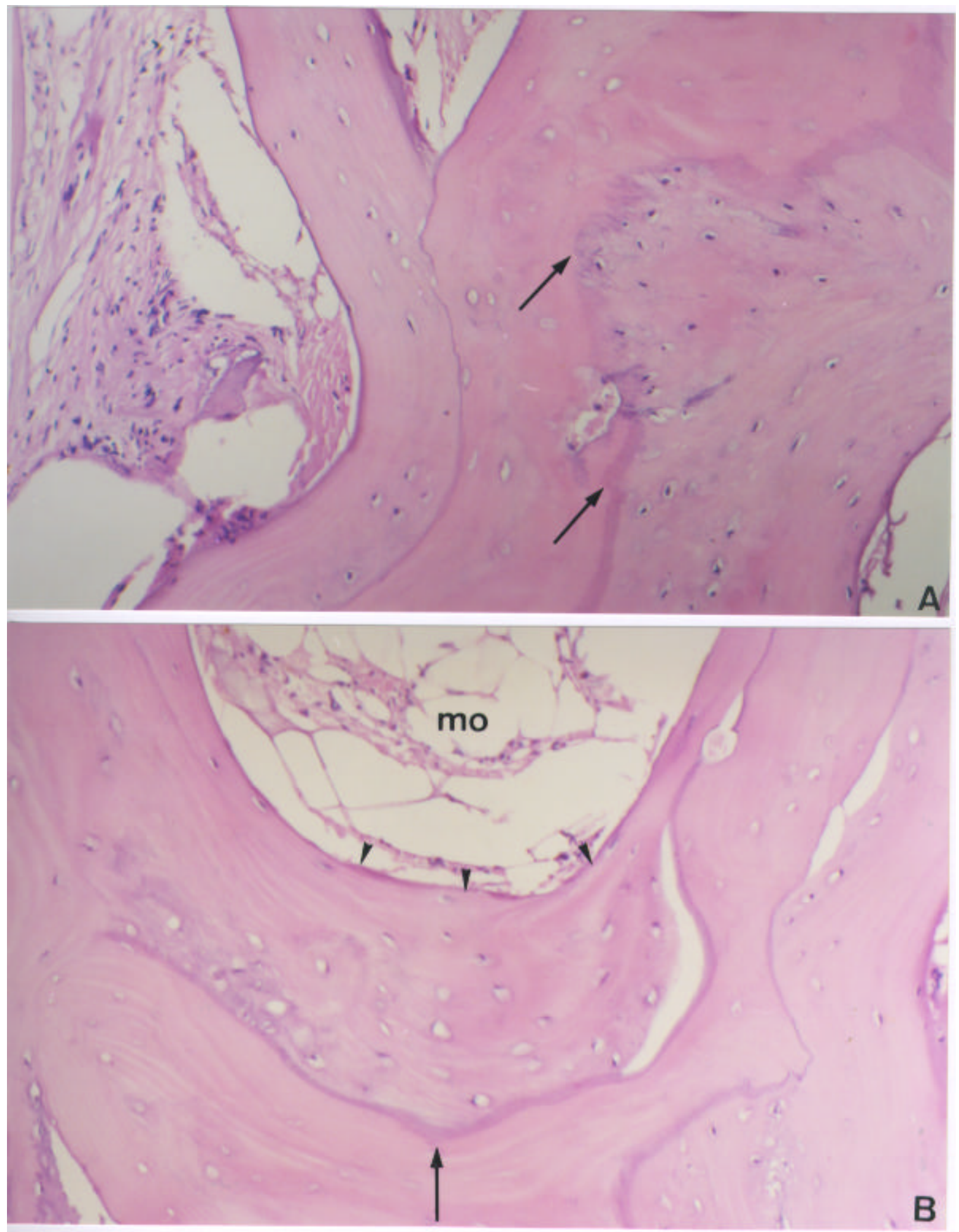

Figura 17 - Aspectos microscópicos do reparo e incorporação do enxerto ósseo de crista ilíaca na área receptora. Observam-se áreas de formação de tecido osteóide primário, ricamente celularizado (setas pequenas) e aleatoriamente depositado, como revelam as linhas 

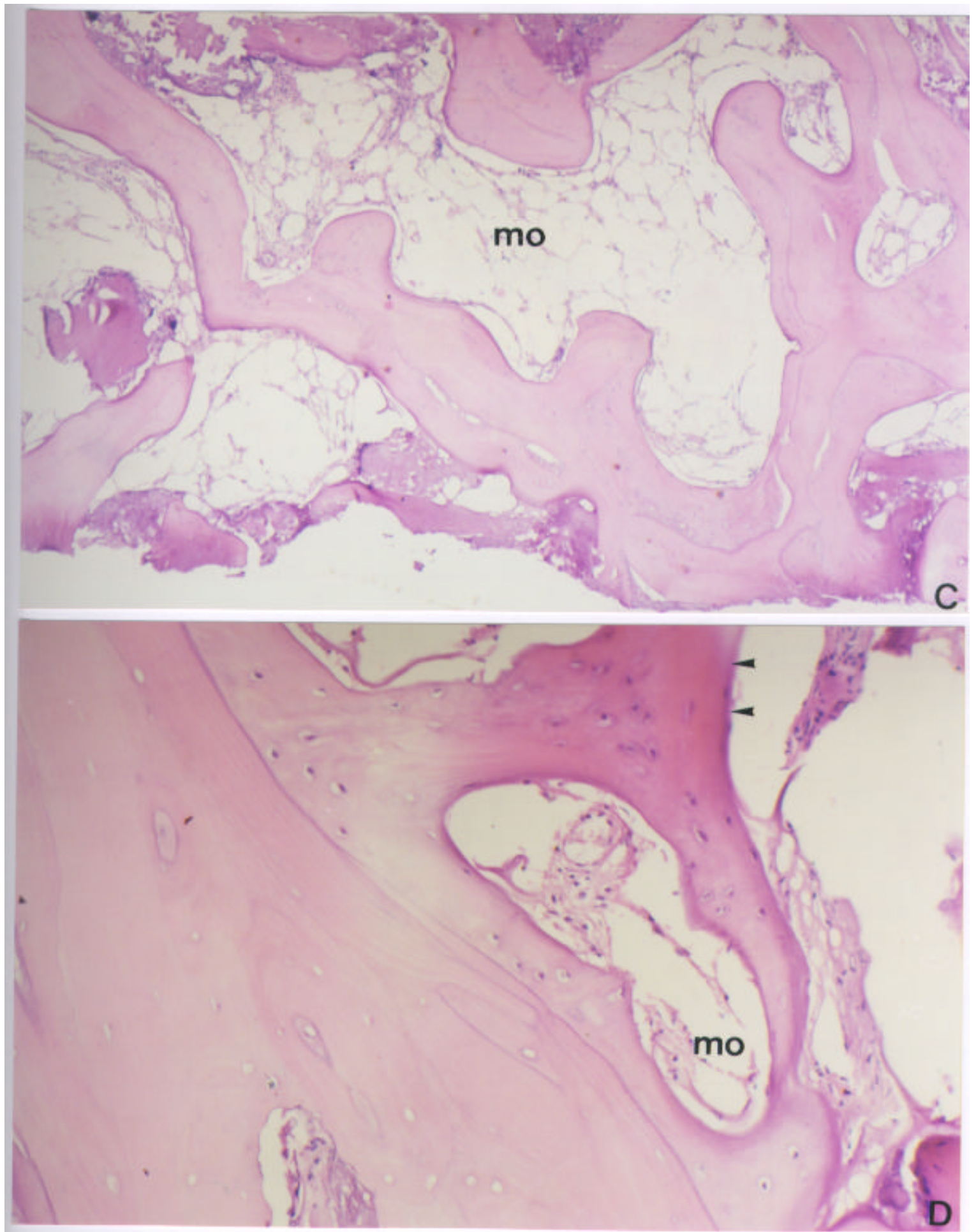

...incrementais irregulares (setas maiores). Gradativamente, no tecido ósseo neoformado, ocorre reorganização da medula óssea (mo), predominantemente adiposa. (Coloração H.E.; aumento original: A, B = 40x; $C=16 x ; D=40 x$ ) 

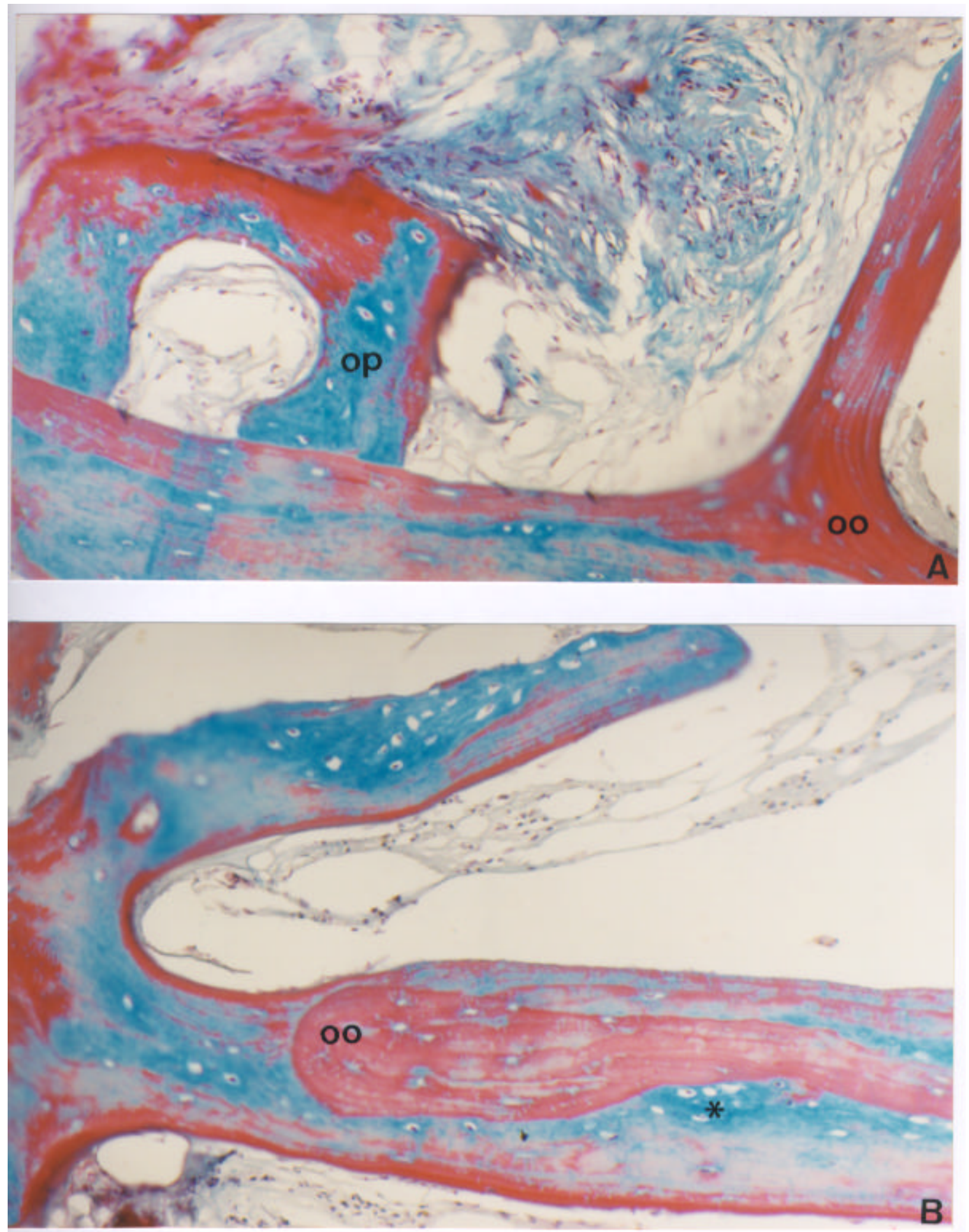

Figura 18 - Áreas de medula óssea fibrosa também foram visualizadas. Observam-se novas trabéculas sendo formadas ora de osso primário (op) ricamente celularizado e desorganizado, ora com osso mais maduro (*) em A e B. Nas fotos C e D, observa-se 

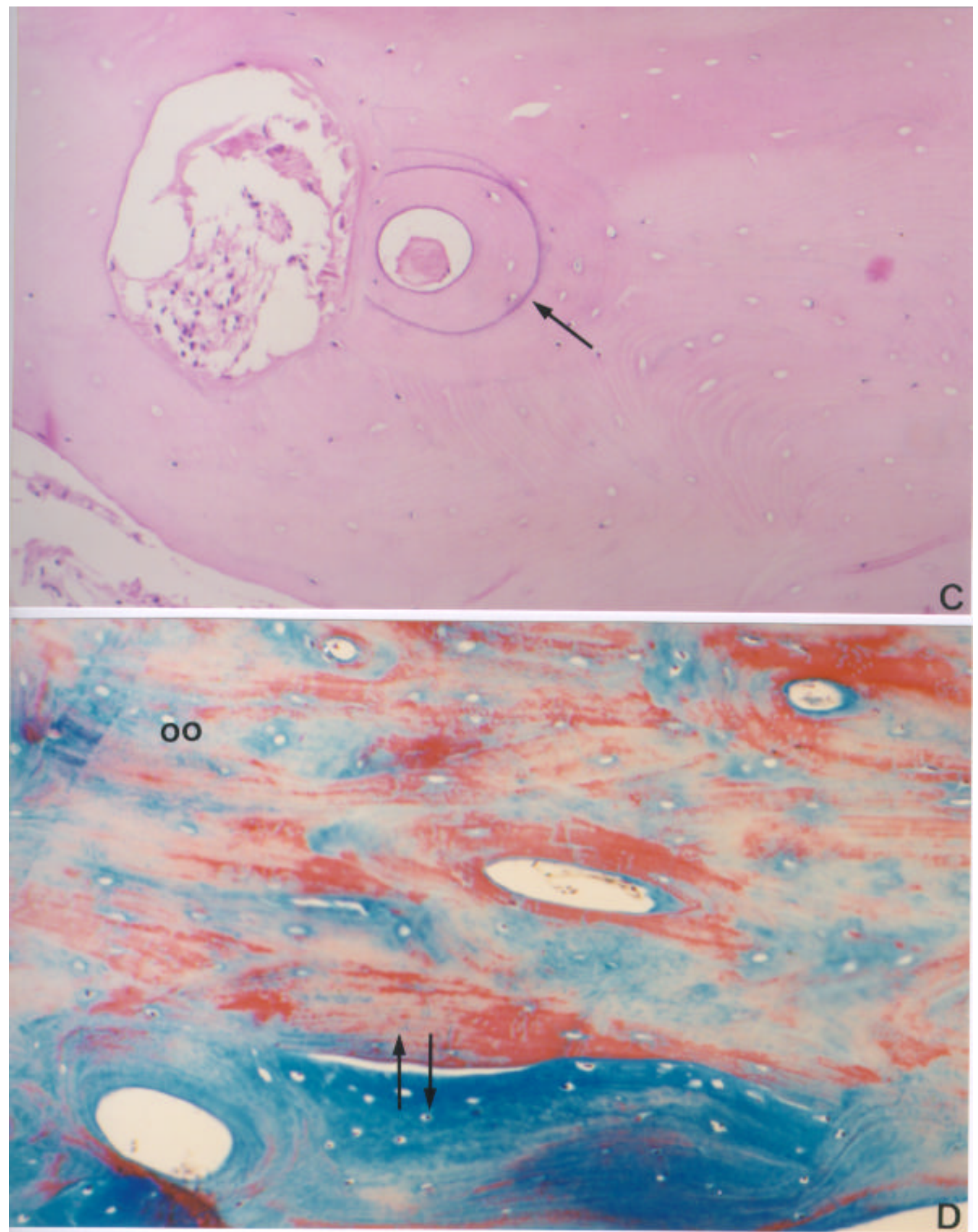

...que o mesmo processo de renovação também ocorre nas corticais (setas). Na coloração de Tricrômico de Mallory, as áreas antigas de osso original (oo) ficam mais destacadas. (Coloração Tricrômico de Mallory; aumento original: $\mathrm{A}, \mathrm{B}$ e $\mathrm{D}=40 \mathrm{x}$; coloração H.E.; aumento original: $C=40 x$ ) 


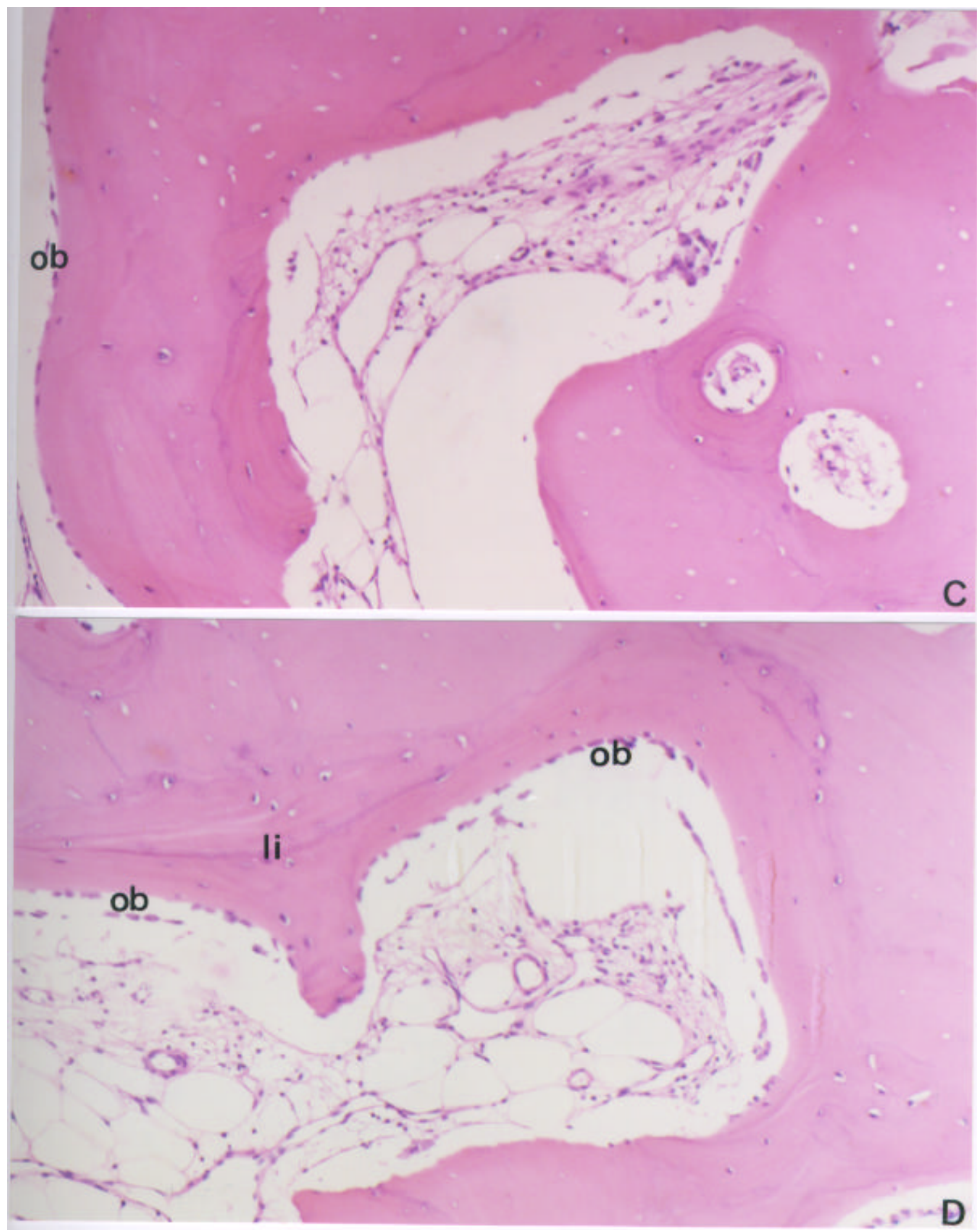

Figura 19 - Aspectos microscópicos do reparo e incorporação do enxerto ósseo do mento. As trabéculas são mais espessas e associadas a novas trabéculas já estabelecidas pela osteogênese induzida e caracterizadas por áreas de osso primário (setas) 


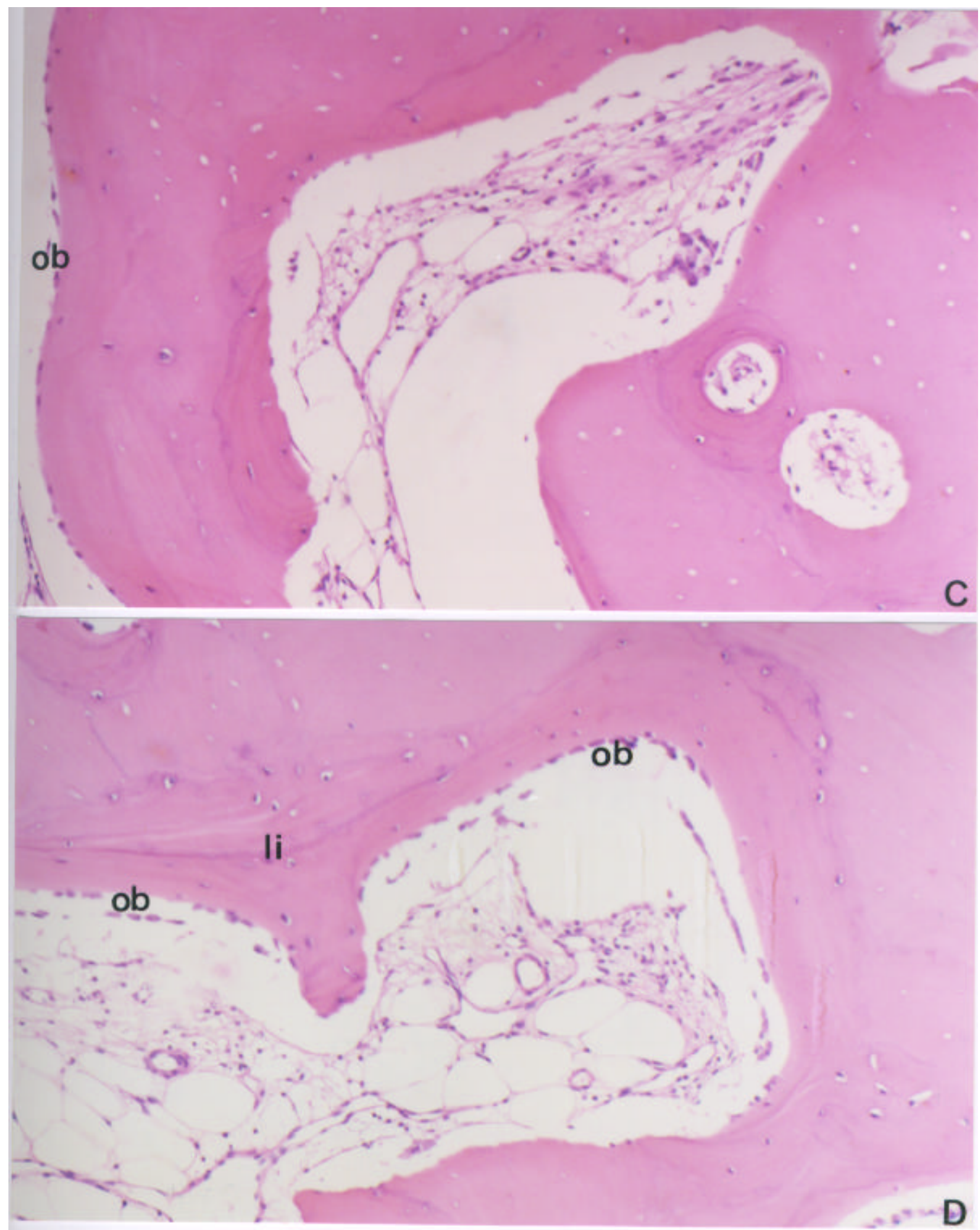

Em D, pode-se observar que as trabéculas ósseas maduras estão em franca renovação e reorganização, denotadas pelas linhas incrementais (li). A osteogênese é destacada pela bem organizada camada de células osteoblásticas superficiais (ob). (Coloração H.E.; aumento original: $A=16 x$; $B, C$ e D $=40 x$ ) 

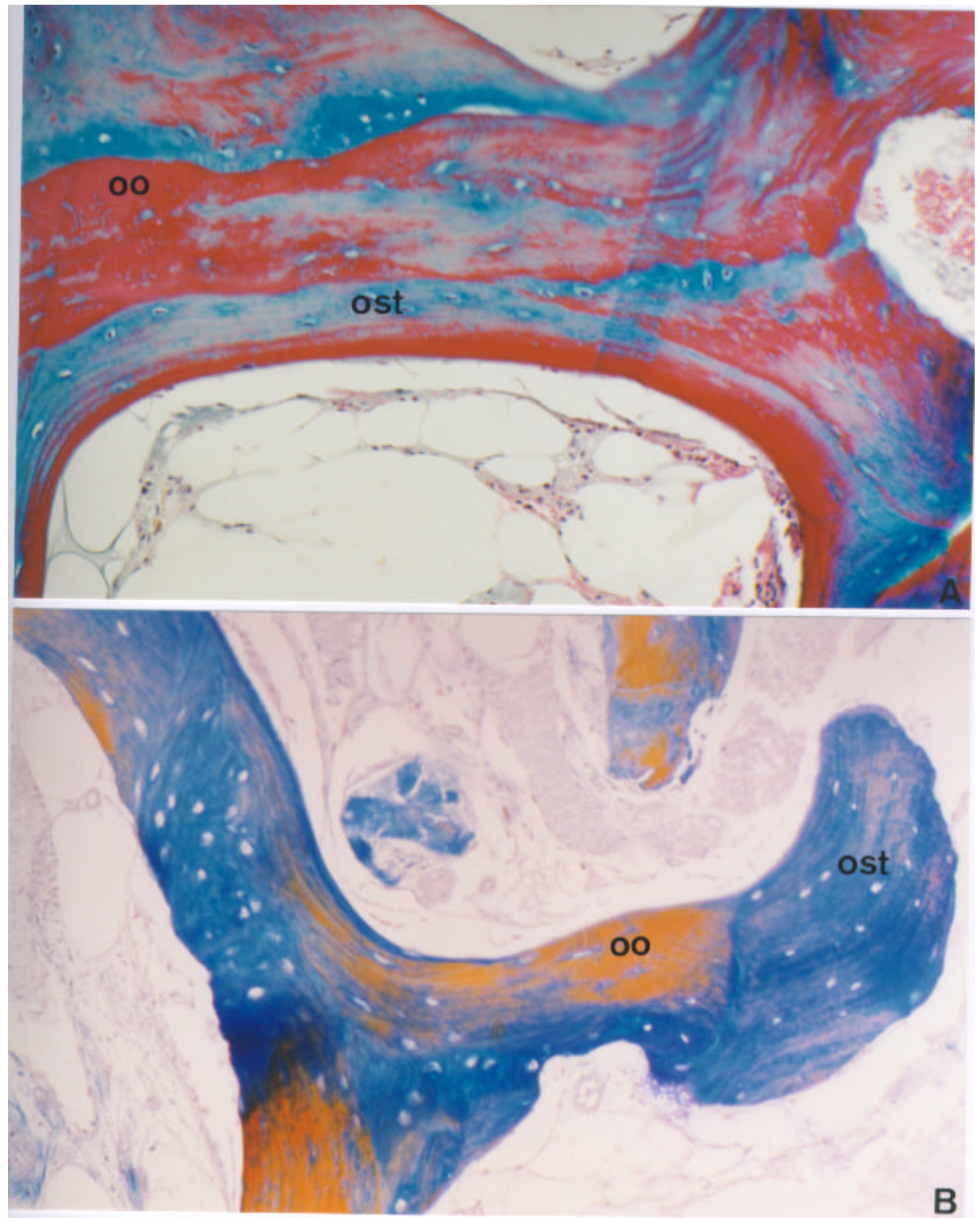

Figura 20 - A coloração tricrômica destacava as áreas ósseas mais mineralizadas e organizadas em lamelas, originariamente adindas do enxerto ósseo da área do mento (oo). Observa-se, também, o osso decorrente da ósteogenese no contexto do reparo e da incorporação (ost). (Coloração Tricômico de Mallory; aumento original; $\mathrm{A}$ e $\mathrm{B}=40 \mathrm{x}$ ) 


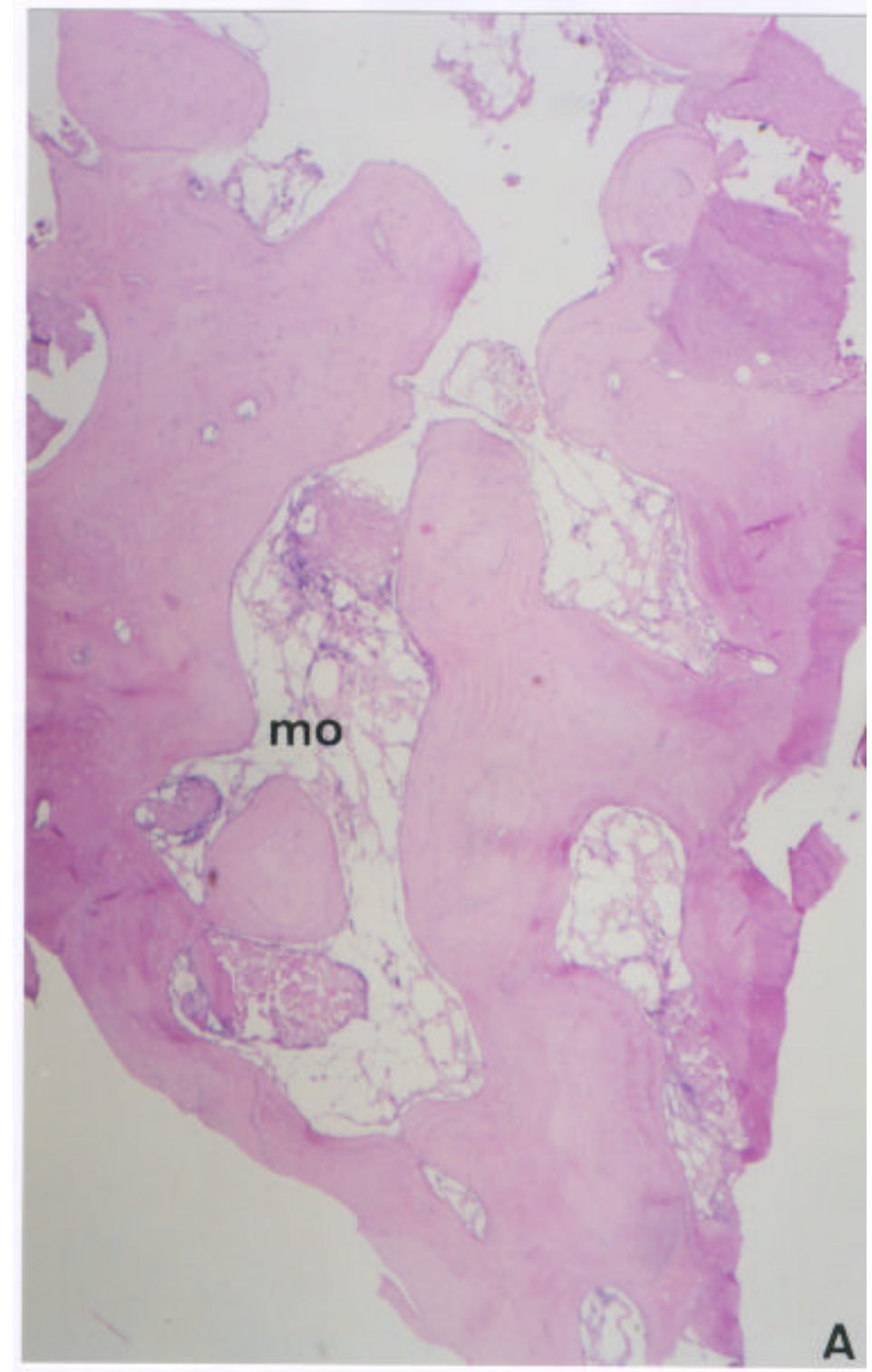

Figura 21 - Aspectos microscópicos denotando a presença de tecido adiposo preenchendo os espaços medulares. Intensa atividade de renovação óssea e osteogênese são notadas, em função da riqueza e aleatoriedade das linhas incrementais (li) e da relação das trabéculas com a medula 

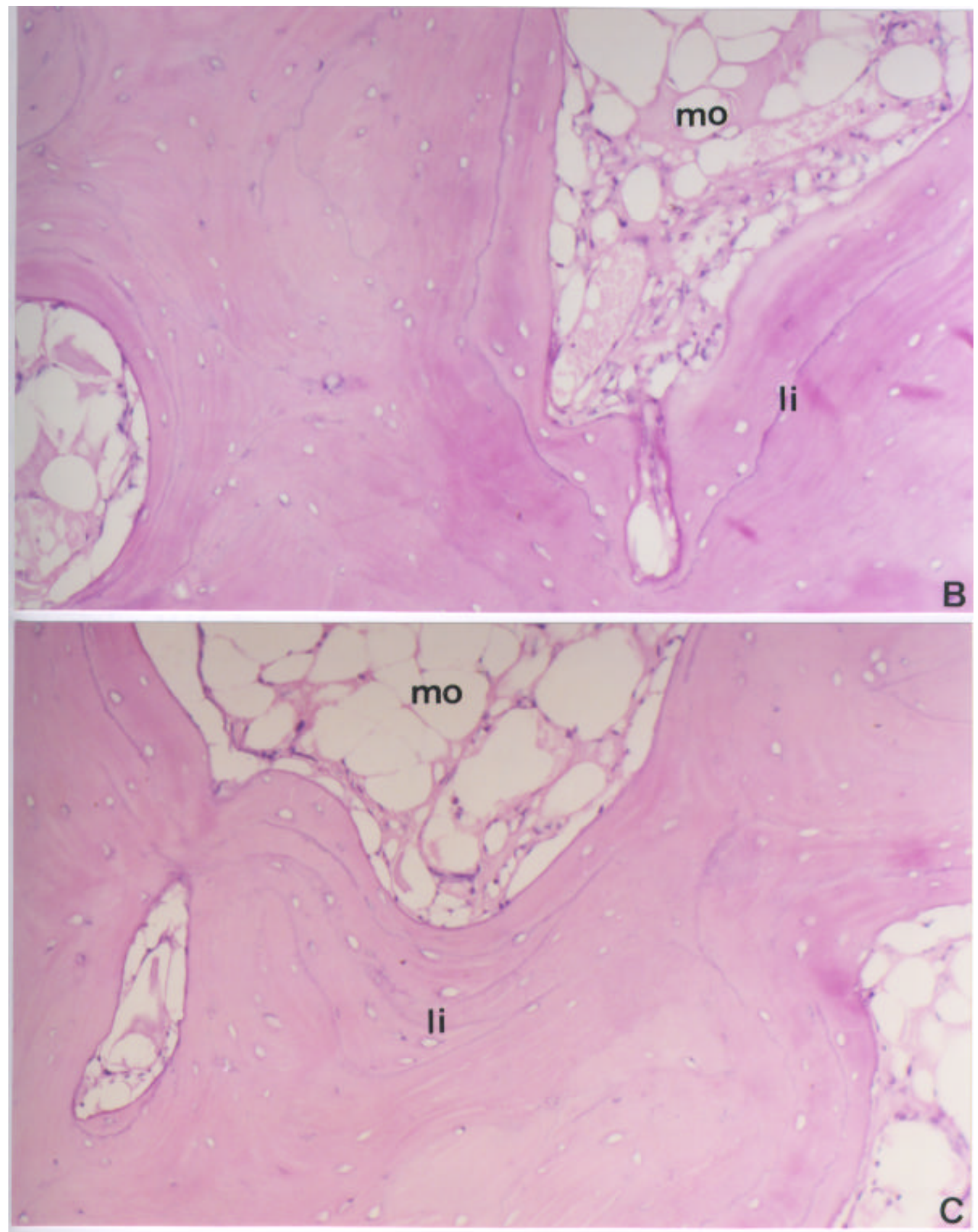

...óssea (mo) em enxertos ósseos mentonianos. (Coloração H.E.; aumento original: $\mathrm{A}=16 \mathrm{x} ; \mathrm{B}$ e $\mathrm{C}=40 \mathrm{x}$ ) 


\subsection{Análise dos traçados das áreas de matriz óssea mineralizada}

O experimento consistiu em estudar a área óssea de espécimes selecionados de dez pacientes, dos quais cinco receberam enxerto ósseo de sínfise mandibular e cinco da crista ilíaca, em diferentes regiões da maxila. Após quatro meses da colocação do enxerto, obteve-se uma amostra destas áreas, da qual foram selecionadas aleatoriamente três regiões de cada espécime, denominadas A, B e C, como citado no capítulo de Material e Métodos.

Os números resultantes das medidas dos traçados das superfícies ósseas destas áreas estão representados na Tabela 2.

Desta forma, dois fatos foram estudados nesta análise:

- Tipo de enxerto: mento e crista ilíaca, e

- Regiões: A, B e C;

compondo assim, seis tratamentos formados pela combinação dos dois fatores acima, obtendo-se cinco repetições de cada tratamento com um total de 30 unidades amostrais. 
Tabela 2 - Números resultantes das medidas dos traçados das superfícies ósseas das regiões A, B e C, obtidas dos enxertos de mento e crista ilíaca.

\begin{tabular}{|c|c|c|c|}
\hline ENXERTOS & REGIÕES & PACIENTES & ÁreA ÓSSEA TOTAL \\
\hline Ilíaco & A & 1 & $2.938,040$ \\
\hline Ilíaco & A & 2 & $2.797,398$ \\
\hline Ilíaco & A & 3 & $5.270,600$ \\
\hline Ilíaco & $\mathrm{A}$ & 4 & $3.484,033$ \\
\hline Ilíaco & $\mathrm{A}$ & 5 & $3.271,106$ \\
\hline Ilíaco & $\mathrm{B}$ & 1 & 616,930 \\
\hline Ilíaco & $\mathrm{B}$ & 2 & $2.853,964$ \\
\hline Ilíaco & $\mathrm{B}$ & 3 & $2.975,465$ \\
\hline Ilíaco & $\mathrm{B}$ & 4 & $3.274,930$ \\
\hline Ilíaco & $\mathrm{B}$ & 5 & $3.963,867$ \\
\hline Ilíaco & $\mathrm{C}$ & 1 & $1.367,940$ \\
\hline Ilíaco & $\mathrm{C}$ & 2 & $1.899,633$ \\
\hline Ilíaco & $\mathrm{C}$ & 3 & $2.992,365$ \\
\hline Ilíaco & $\mathrm{C}$ & 4 & $1.831,428$ \\
\hline Ilíaco & $\mathrm{C}$ & 5 & $3.559,700$ \\
\hline Mento & A & 6 & $5.102,134$ \\
\hline Mento & A & 7 & $2.552,866$ \\
\hline Mento & A & 8 & $6.719,266$ \\
\hline Mento & A & 9 & $5.072,500$ \\
\hline Mento & A & 10 & $5.777,600$ \\
\hline Mento & $\mathrm{B}$ & 6 & $5.622,367$ \\
\hline Mento & $\mathrm{B}$ & 7 & $2.877,297$ \\
\hline Mento & $\mathrm{B}$ & 8 & $4.902,999$ \\
\hline Mento & $\mathrm{B}$ & 9 & $2.484,762$ \\
\hline Mento & $\mathrm{B}$ & 10 & $4.348,383$ \\
\hline Mento & $\mathrm{C}$ & 6 & $2.543,099$ \\
\hline Mento & $\mathrm{C}$ & 7 & $3.627,966$ \\
\hline Mento & $\mathrm{C}$ & 8 & $3.468,030$ \\
\hline Mento & $\mathrm{C}$ & 9 & $1.803,830$ \\
\hline Mento & $\mathrm{C}$ & 10 & $3.210,137$ \\
\hline
\end{tabular}


O modelo matemático para análise da variância foi o de delineamento inteiramente ao acaso, com tratamentos dispostos em esquema fatorial $2 \times 2{ }^{66}$, cuja expressão é a seguinte:

$$
y_{i j k}=m+O_{i}+A_{j}+(O A)_{i j}+e_{i j k}
$$

onde:

$\mathrm{y}_{\mathrm{ijk}}=$ valor observado referente ao i-ésimo tipo de enxerto na j-ésima região;

$\mathrm{m}$ = fator fixo, estimado pela média geral;

$\mathrm{O}_{\mathrm{i}} \quad$ efeito do i-ésimo do tipo de enxerto (Mento ou Ilíaco);

$\mathrm{A}_{\mathrm{j}}=$ efeito da j-ésima região(A, B e C);

$(\mathrm{OA})_{\mathrm{ij}}=$ efeito da interação do i-ésimo enxerto com a j-ésima região;

$\mathrm{e}_{\mathrm{ijk}}=$ erro aleatório (variação do acaso sobre as observações do i-ésimo enxerto, na j-ésima região), supostos homocedásticos, independentes e normalmente distribuídos.

O esquema de análise da variância e teste $F$ para os tratamentos foi o seguinte:

\begin{tabular}{|lcccc|}
\hline \multicolumn{1}{|c}{$\begin{array}{c}\text { Causas da } \\
\text { Variação }\end{array}$} & G.L. & S.Q. & Q.M. & F \\
\hline Tipos de enxertos & 1 & SQ Enxertos & QM Enxertos & QM Enxertos/QM Res \\
Regiões & 2 & SQ Regiões & QM Regiões & QM Regiões/QM Res \\
$\begin{array}{l}\text { Tipos de enxertos x } \\
\text { Regiões }\end{array}$ & 2 & $\begin{array}{c}\text { SQ Enxertos x } \\
\text { Regiões } \\
\text { Resíduo }\end{array}$ & $\begin{array}{c}\text { QM Enxertos x } \\
\text { Regiões }\end{array}$ & $\begin{array}{c}\text { QM Enxertos x Regiões / } \\
\text { QM Res }\end{array}$ \\
\hline Total & 24 & SQ Resíduo & QM Resíduo & \\
\hline
\end{tabular}

onde SQ (somas de quadrados) e QM (quadrados médios) podem ser obtidos em literatura da área. 
A razão QM (Causas da Variação)/QM Res. testa as hipóteses:

$\mathrm{H}_{0}$ : não existe diferença entre as médias de tipos de enxertos (QM Enxertos/QM Res);

$\mathrm{H}_{0}$ : não existe diferença entre as médias das regiões (QM Regiões / QM Res);

$\mathrm{H}_{0}$ : não existe diferença entre as médias da interação de tipos de enxerto com regiões (QM Enxerto x Regiões / QM Res).

Considerou-se como nível mínimo de significância (máximo de erro) para rejeição dessa hipótese, 5\%, ou seja, sempre que o valor da probabilidade do teste $F$ for menor ou igual a 0,05 ( $\alpha \leq$ 0,05) não se rejeita que há diferença significativa entre as médias de tipos de enxertos, de regiões e da interação entre eles, e procede-se então ao detalhamento da análise pelo teste de Tukey para comparação das médias duas a duas, considerando-se, também, um nível mínimo de significância de $5 \%(\alpha \leq 0,05)$.

O teste de Tukey testa a hipótese, por exemplo:

$$
\mathrm{H}_{0}: \mathrm{m}_{\mathrm{M}}-\mathrm{m}_{\mathrm{I}}=0
$$

sendo $\mathrm{m}_{\mathrm{M}}$, $\mathrm{m}_{\mathrm{I}}$, respectivamente, as médias obtidas pelos tipos de enxertos: mento e ilíaco; e assim por diante, para as médias do outro fator e da interação entre eles, isto é, verificam se as 
médias, em pares, são estatisticamente iguais ou diferentes, utilizando, para rejeitar a hipótese de igualdade uma diferença minima significativa, dada por:

$$
\Delta=d . m . s .=q \sqrt{\frac{Q M \operatorname{Re} s i d u o}{r}}
$$

onde:

$\Delta=$ d.m.s. = diferença minima significativa;

q é obtido em tabela do teste de Tukey, com um nivel de probabilidade (erro) $\alpha$ pré-definido (aqui tomado $\alpha \leq 0,05$ ), chamado de amplitude total estudentizada;

QM residuo = quadrado médio do resíduo, obtido na análise da variância do modelo adotado;

$\mathbf{r}=$ número de repetições (amostras).

As médias obtidas pelos tipos de enxertos são consideradas diferentes estatisticamente se, por exemplo, $m_{M}-m_{I} \geq$ d.m.s. calculada.

\subsubsection{Análise exploratória dos dados}

Para que os modelos de análise descritos tenham validade e os testes tenham poder, são necessárias serem satisfeitas as pressuposições: 
- homogeneidade de variâncias, ou seja, só podem ser comparados tratamentos com variâncias homogêneas entre si;

- independência dos erros (uma observação tem que ser independente da outra);

- erros (variação do acaso) com distribuição normal (ou aproximadamente normal).

Para testar essas pressuposições procedeu-se à análise exploratória de dados, pela Análise Gráfica dos Residuos ${ }^{30}$, que consiste em plotar num diagrama de dispersão os valores estimados pelo modelo da análise da variância versus os resíduos padronizados (erro referente a cada observação dividido pelo desvio padrão amostral). A forma desse gráfico permite a detecção falta de independência e existência de heterogeneidade regular (que pode ser eliminada pelo uso de uma transformação adequada) ou irregular (que não permite transformação). O intervalo dos resíduos padronizados detecta se há algum(uns) valor(es) desviando-se da normalidade. Consideram-se normalmente distribuidos os resíduos que estiverem no intervalo de -3 a 3

A análise gráfica dos resíduos, apresentada na Figura 22, mostra, pela forma do gráfico, que há homogeneidade de 
variâncias e que não há sinais de violação de independência entre as observações. A pressuposição de normalidade também não foi violada, já que os resíduos encontram-se dentro do intervalo de $3 a+3$. Essas pressuposições nos garantem a validade da análise feita pelo modelo matemático proposto.

A título de curiosidade, foi feito um diagrama de "ramos e folhas" dos dados, comprovando a não existência de outliers (dados discrepantes) em relação aos demais.

A Figura 23 mostra o diagrama de "ramos e folhas" (Stemand-leaf display) dos dados da variável área óssea total das regiões, que consiste na ordenação programada de forma a ver a distribuição dos dados e salientar os possíveis outliers no grupo. Pode-se observar, que a distribuição dos dados está bastante simétrica, indicando um bom controle na obtenção das medidas. 
Diagrama de Dispersão dos Valores Estimados vs. Resíduos Padronizados Área Óssea Total

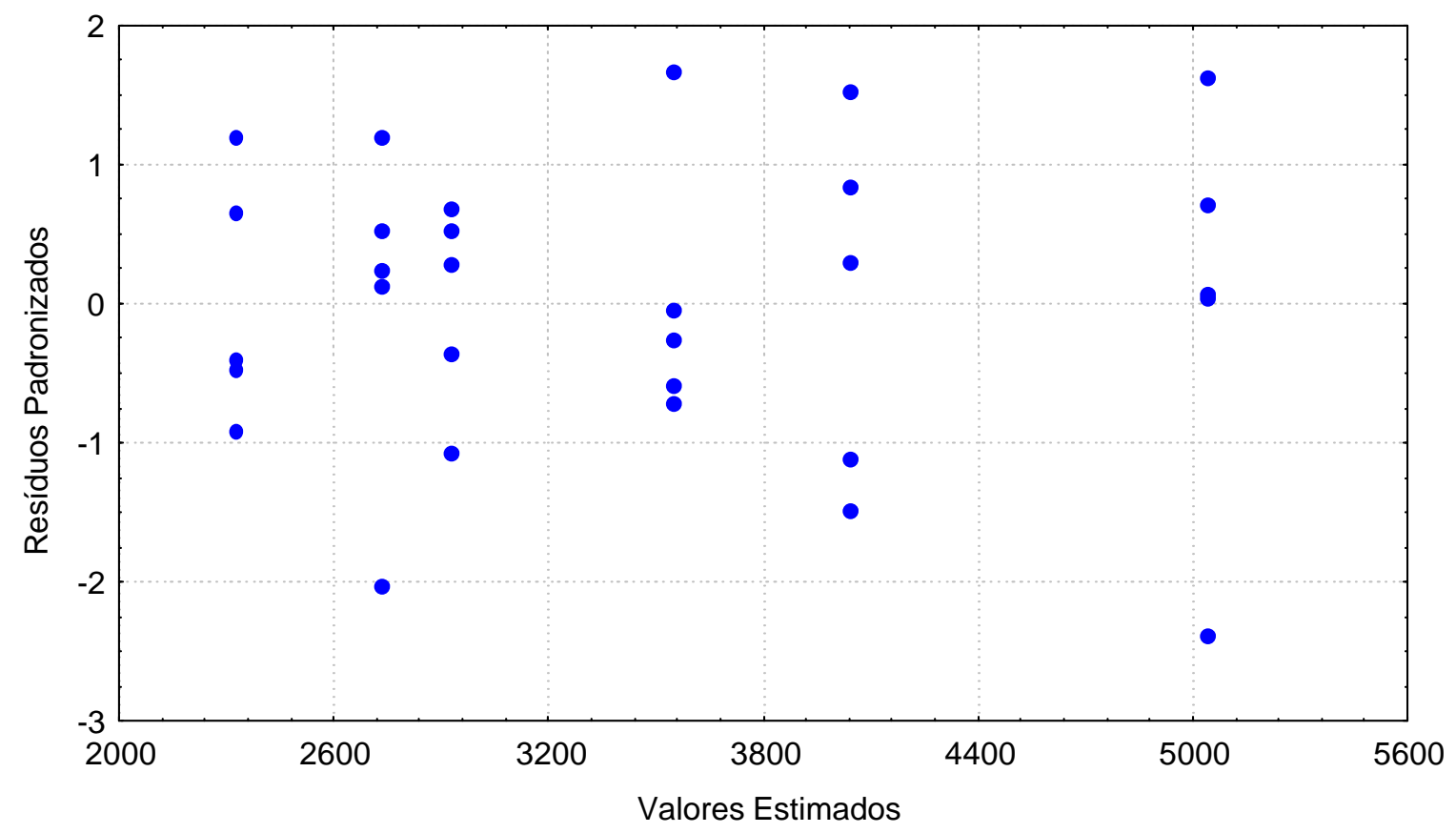

Figura 22 - Análise gráfica dos resíduos dos dados da variável área óssea total das regiões

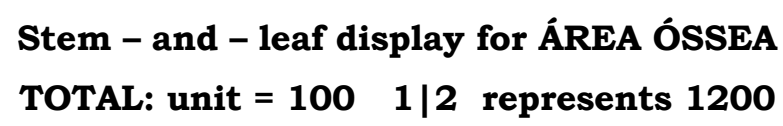

$\begin{array}{cl:l}1 & 0^{\circ} & 6 \\ 2 & 1^{*} & 3 \\ 5 & 1^{\circ} & 888 \\ 6 & 2^{*} & 4 \\ 14 & 2^{\circ} & 55788999 \\ (5) & 3^{*} & 22244 \\ 11 & 3^{\circ} & 569 \\ 8 & 4^{*} & 3 \\ 7 & 4^{\circ} & 9 \\ 6 & 5^{*} & 012 \\ 3 & 5^{\circ} & 67 \\ 1 & 6^{*} & \\ 1 & 6^{\circ} & 7\end{array}$

* dígitos secundários $0,1,2,3,4$

${ }^{\circ}$ dígitos secundários $5,6,7,8,9$

Figura 23 - Diagrama de ramos e folhas dos dados da variável área óssea total das regiões 


\subsubsection{Análise da variância e teste de Tukey}

A análise da variância para a variável área óssea total das regiões, em função das causas de variação (fatores) em estudo: tipos de enxertos e regiões e sua interação, encontra-se na Tabela 3, onde se nota que foram detectadas diferenças significativas, entre as médias de tipos de enxertos e de regiões (em nível de 5\%), e que para a interação (combinação dos enxertos com as regiões), o teste $F$ não acusou diferença significativa. O coeficiente de variação obtido de $33,87 \%$ indica uma boa precisão do experimento.

Tabela 3 - Análise da variância e teste $F$ para a variável área óssea total, em função dos fatores (causas da variação) tipos de enxertos, regiões e sua interação

\begin{tabular}{|c|c|c|c|c|}
\hline $\begin{array}{l}\text { CAUSAS DA } \\
\text { VARIAÇÃ O }\end{array}$ & G.L. & S.Q. & Q.M. & $\mathbf{F}$ \\
\hline Tipos de enxerto & 1 & $9.651 .299,5875$ & $9.651 .299,5875$ & $7,1063^{*}$ \\
\hline Regiões & 2 & $13.948 .421,8794$ & $6.974 .210,9397$ & $5,1351^{*}$ \\
\hline Enxertos x Regiões & 2 & $1.110 .919,8460$ & $555.459,9230$ & $0,4090 \mathrm{~ns}$ \\
\hline Resíduo & 24 & $32.595 .345,0126$ & $1.358 .139,3755$ & \\
\hline TOTAL & 29 & $57.305 .986,3255$ & $18.539 .109,8257$ & \\
\hline \multicolumn{5}{|c|}{$\begin{array}{l}\text { Média Geral }=3440,3545 \\
\text { Coeficiente de Variação }=33,87 \%\end{array}$} \\
\hline
\end{tabular}


O detalhamento da análise, pelo teste de Tukey, para as médias da área óssea total devidas a cada tipo de enxerto estudado, é mostrado na Tabela 4 e Figura 24.

Confirmando o resultado obtido pela análise da variância, o teste de Tukey detectou diferença significativa para as médias da área óssea total entre os dois tipos de enxertos, sendo que o que apresentou maior área óssea total foi o enxerto de mento. O detalhamento da análise, através do teste de Tukey, para as médias da área óssea total devidas a cada região estudada é mostrado na Tabela 5 e Figura 25, confirmando o resultado obtido pela análise da variância da ocorrência de diferença estatisticamente significativa entre as médias das regiões, sendo que a região A apresentou a maior área óssea total enquanto que a região $\mathrm{C}$ a menor área óssea total. A região $\mathrm{B}$ ficou em posição intermediária, não diferindo estatisticamente da região A nem da região $\mathrm{C}$.

Como o resultado da análise da variância para a interação enxertos x região não foi significativo, será apresentado na Tabela 6 somente as médias da variável área óssea total para as combinações de enxertos com regiões. 
Pela Tabela 6 e Figura 26, pode ser visualizado que dentro das regiões não houve diferença significativa entre as médias dos tipos de enxertos. Esse resultado confirma, pois, o obtido pela análise da variância, de que o fator enxertos não depende do fator regiões, ou vice-versa.

Tabela 4 - Médias da área óssea total relacionadas a cada tipo de enxerto estudado, e comparação pelo teste de Tukey

\section{Ossos}

Mento

Ilíaco

d.m.s. $(5 \%)$

\section{MÉDIAS}

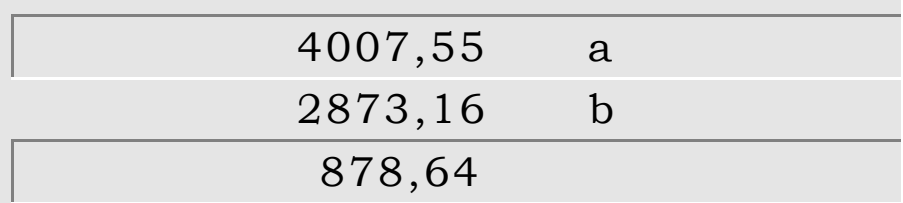

Médias seguidas de letras minúsculas diferentes, diferem entre si em nivel de $5 \%(\alpha \leq 0,05)$.

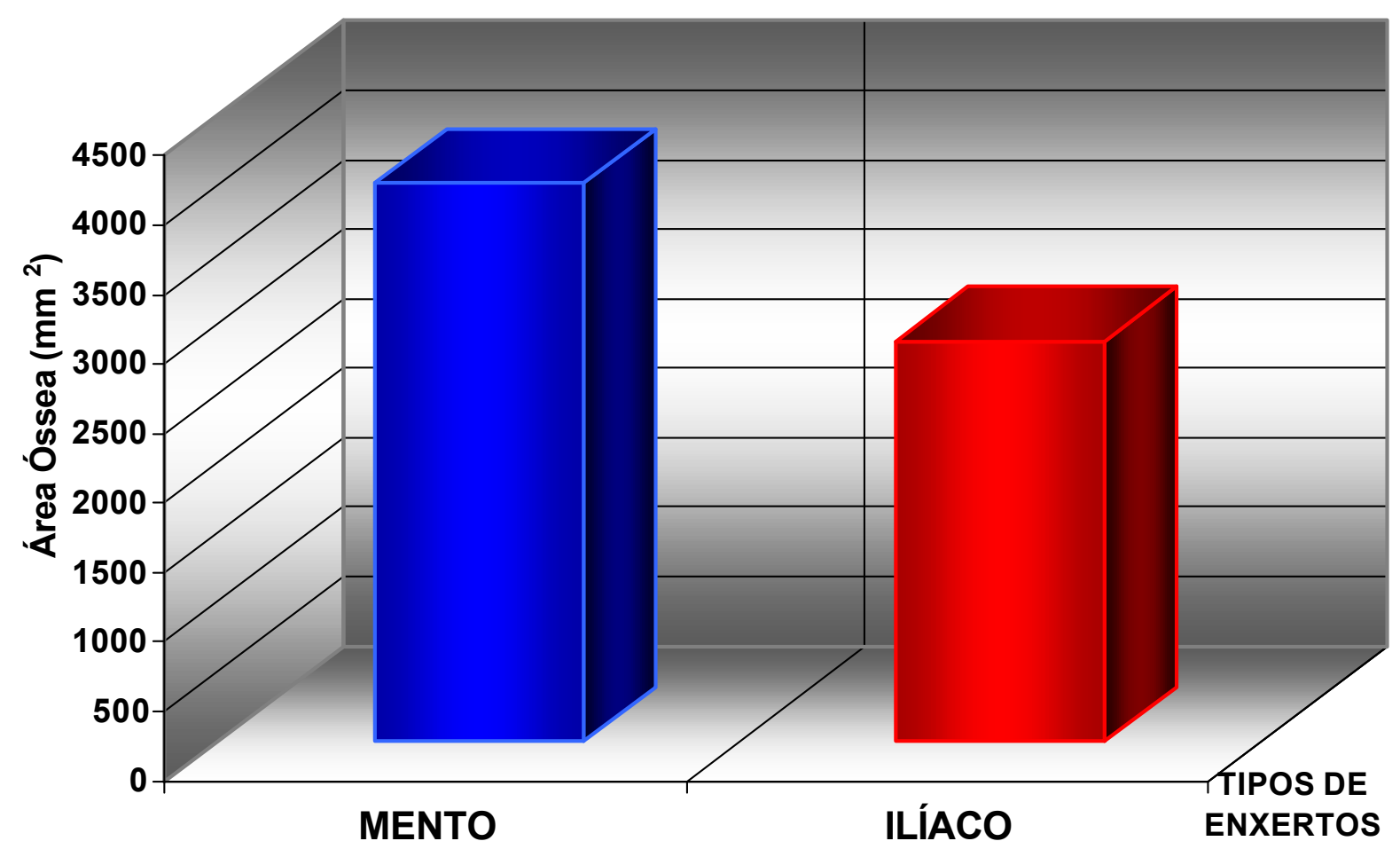

Figura 24 - Médias da área óssea total relacionadas a cada tipo de enxerto estudado 
Tabela 5 - Médias da área óssea total relacionadas a cada região estudada e comparação pelo teste de Tukey

\section{REGIÕES}

A
B
C

d.m.s. (5\%)

\section{MÉdIAS}

$4298,55 \quad$ a

$3392,10 \quad a b$

$2630,41 \quad b$

1300,91

Médias seguidas de letras minúsculas diferentes, diferem entre si em nivel de $5 \%(\alpha \leq 0,05)$.

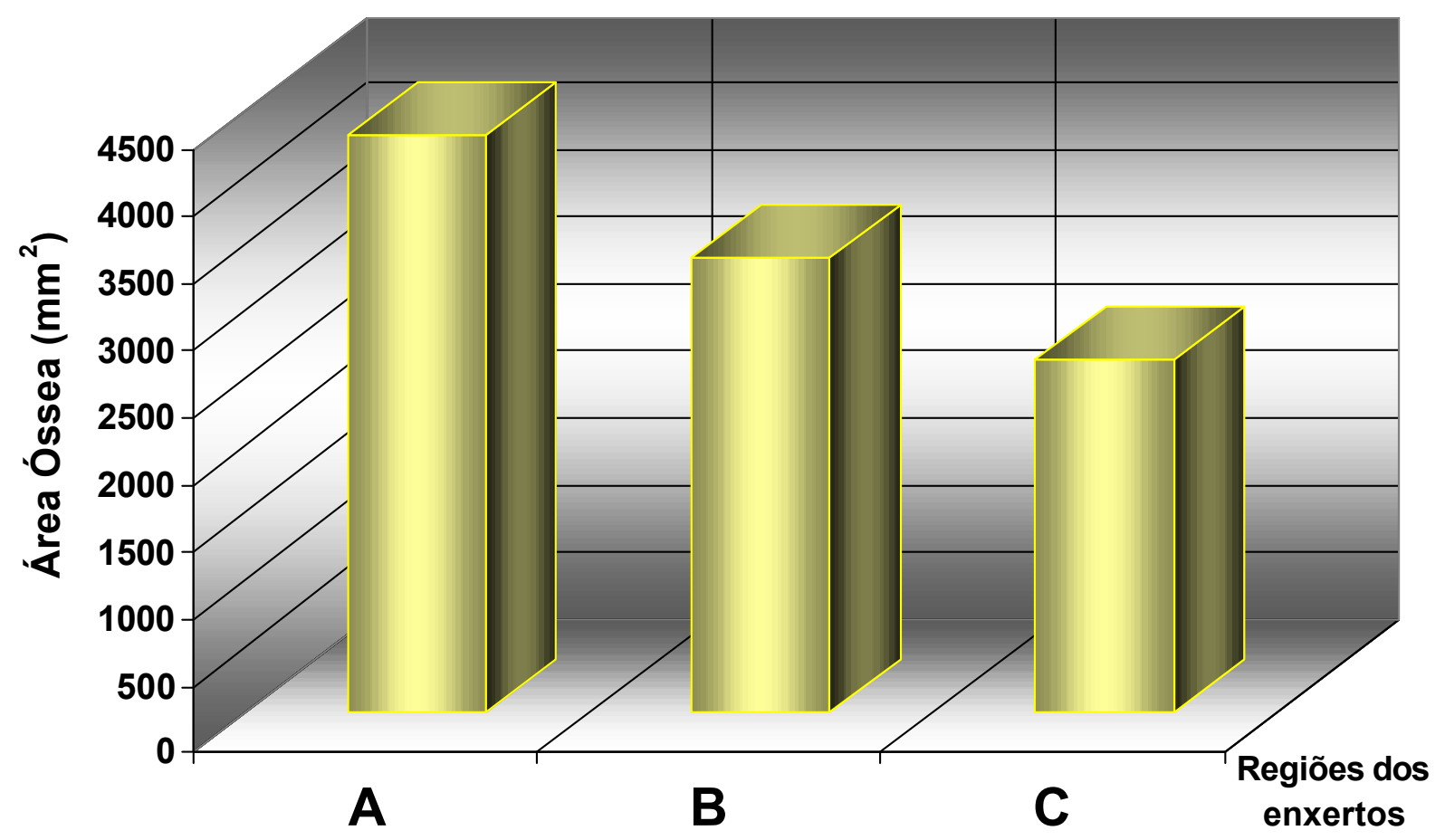

Figura 25 - Médias originais da área óssea total relacionadas a cada região de análise estudada 
Tabela 6 - Médias da área óssea total relacionadas a cada tipo de enxerto, dentro de cada região de análise estudada

TIPOS DE

ENXERTO

Mento

Ilíaco
A $\mathbf{R} \mathbf{A} \mathbf{S}$

A

B

C

$4.047,16$

$2.930,61$

$2.737,03$

$2.330,21$

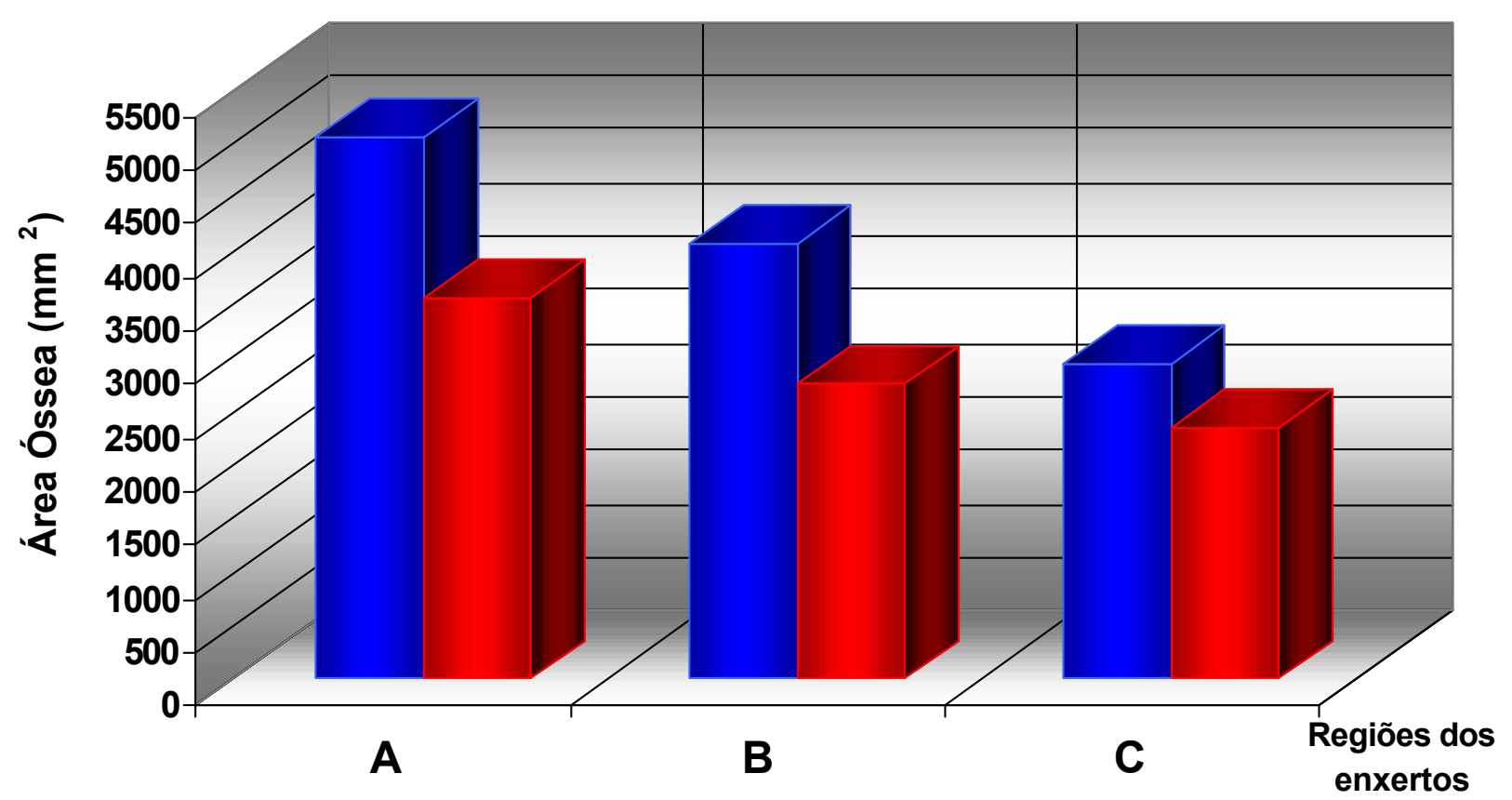

MENTO — ILÍACO

Figura 26 - Médias originais da área óssea total relacionadas a cada tipo de enxerto, dentro de cada região de análise estudada 


\subsection{Observações clínicas}

No momento da obtenção dos espécimes, foi possível identificar em todos os casos tratados uma boa incorporação do enxerto ao osso residente. Apesar de se detectar índices variáveis de reabsorção, todos os casos ofereceram excelentes condições de espessura óssea para a colocação dos implantes osseointegrados (Figuras 27 e 28). Tais reabsorções foram identificadas observando-se a distância entre o nível da superfície óssea vestibular e a cabeça dos parafusos utilizados na fixação dos enxertos. Parece existir uma tendência a uma menor reabsorção dos enxertos mentonianos, porém há que se considerar a maior dimensão dos enxertos de crista ilíaca.

Durante a inserção dos implantes, em nenhum momento se constatou qualquer fragilidade da região de união entre enxerto e rebordo, mesmo quando requerido torque máximo de inserção. No total, foram colocados 35 implantes do Sistema Branemark sendo 4 de $5,0 \mathrm{~mm}$ de diâmetro e 31 de $3,75 \mathrm{~mm}$. Os comprimentos variaram dependendo da estrutura óssea disponível.

No ato da inserção dos implantes, também considerou-se a qualidade óssea pelo torque necessário para o rosqueamento das 
fixações, acusado pelo motor do equipamento. Em nenhum dos sítios implantados praticou-se a confecção de tapping, sendo que os casos de mento necessitaram uma maior demanda de torque para a completa inserção do implante. Do ponto de vista clínico, grosseiramente poderia estabelecer-se como tendência de qualidade óssea: II para o mento e II ou III para o ílio LeKholm, ZARB

Nenhum dos implantes colocados foi perdido até a presente data. Destes, aguardou-se período mínimo de seis meses de sepultamento para a confecção e instalação das próteses. Estes pacientes encontram-se, agora, com períodos variáveis de tempo de proservação (4 a 12 meses), contados desde a reabertura das fixações para a colocação dos intermediários de cicatrização, sem evidências de quaisquer anormalidades. Até o momento, depreende-se que os procedimentos de reconstrução por enxerto ofereceram condições favoráveis à osseointegração. 

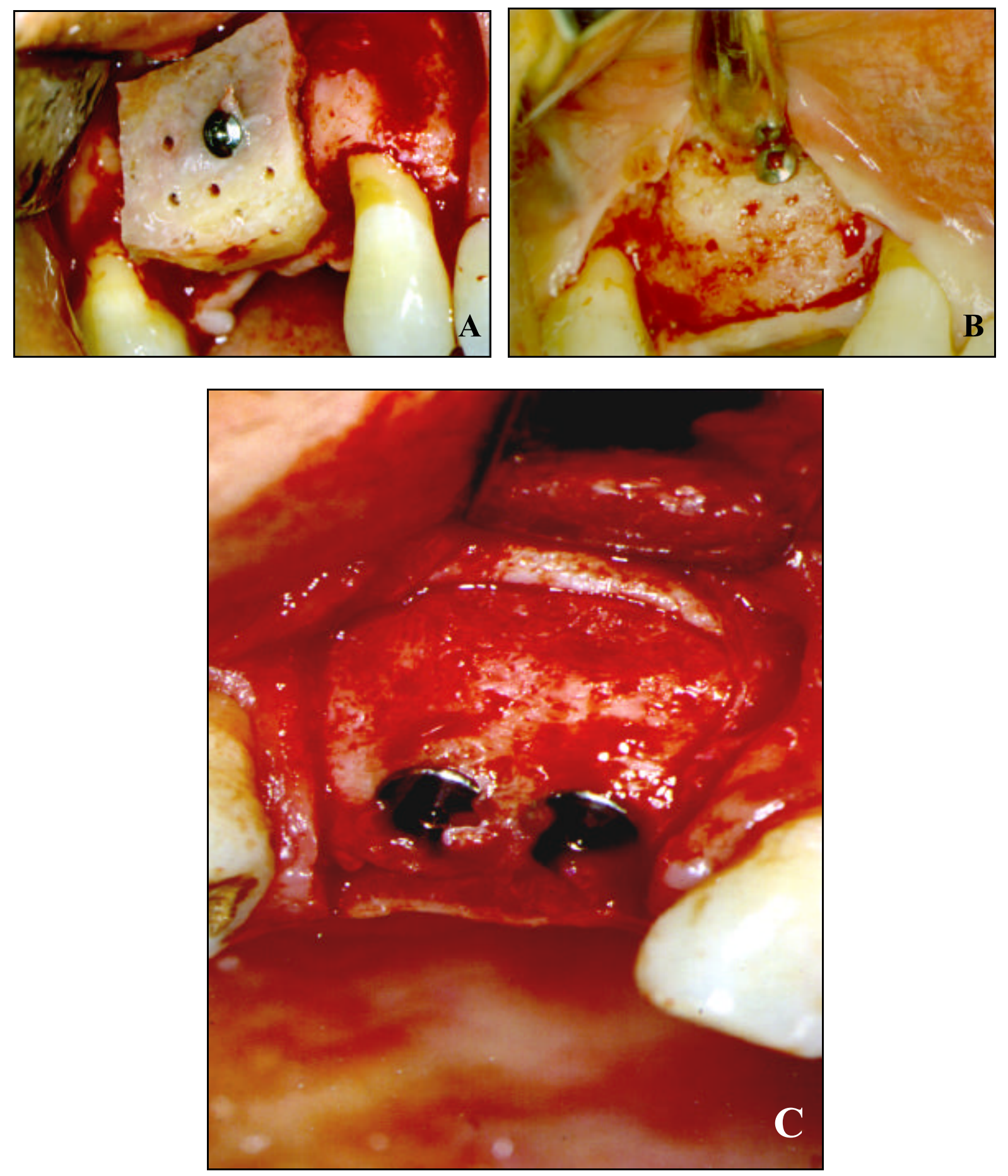

Figura 27 - A) aspecto clínico no momento da reconstrução; B) quatro meses após demonstrando a integração do enxerto de crista ilíaca; C) no momento da segunda fase cirúrgica 

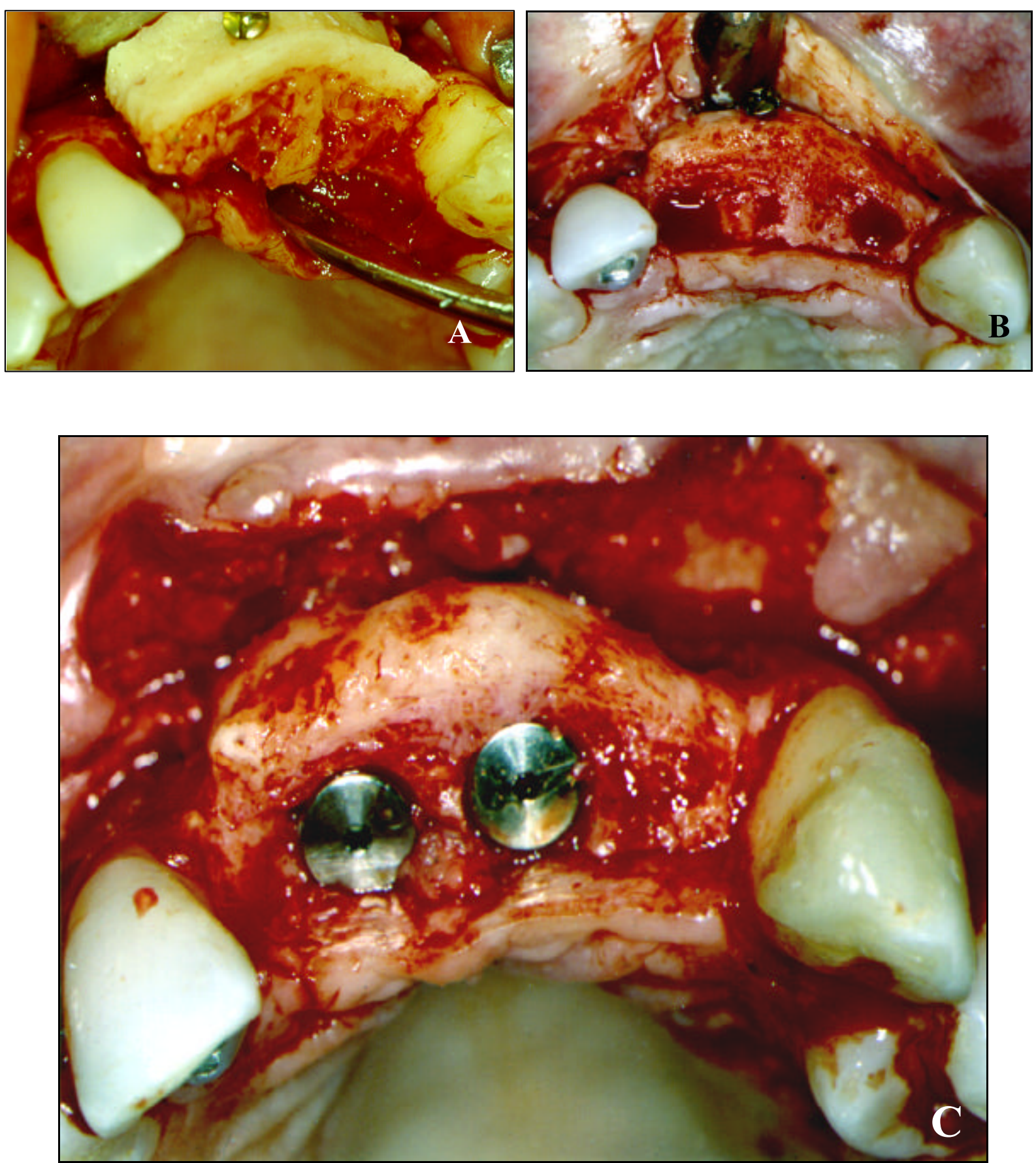

Figura 28 - A) aspecto clínico do rebordo alveolar maxilar atrófico com enxerto de mento; B) quatro meses após a reconstrução demonstrando a boa integração do enxerto; C) instalação de dois implantes osteointegrados 


\section{DISCUSSÃO}

Variadas alternativas cirúrgicas existem a fim de possibilitar o aumento de volume ósseo em regiões de rebordo inadequadas para a reabilitação com implantes osseointegrados 87; 88. Materiais diversos também encontram-se disponíveis, sintéticos e orgânicos, cada qual com suas características, propriedades e indicações específicas 53, 58, 80, 87. Dentre estes, destacam-se os enxertos ósseos autógenos pela sua capacidade osteogênica, baixa imunogenicidade, versatilidade e pela possibilidade de reconstruir defeitos de extensões variadas 49, 69, $75,97$.

Algumas desvantagens, no entanto, acompanham alguns procedimentos de enxertia óssea autógena, como a necessidade de se intervir cirurgicamente em outra parte do corpo, buscando-se a área doadora, o que traz maiores desconfortos ao paciente 23,43 , 96. Além disto, a necessidade de outra equipe cirúrgica e anestesia geral em ambiente hospitalar onera o procedimento, não permitindo seu emprego a todos os indivíduos que dele necessitem. 
Com o intuito de aproveitar as propriedades biológicas destes enxertos, buscam-se áreas doadoras com menor morbidade, e com quantidade e qualidade de tecido ósseo suficientes para garantir condições de reconstrução do rebordo. Regiões da própria maxila e mandibula oferecem tais condições, destacando-se as áreas de túber, retromolar e sínfise mandibular, pela possibilidade de manipulação pela própria equipe de cirurgiões-dentistas e passiveis de serem realizadas sob anestesia local em ambiente ambulatorial 8, 31, 55, 56, 57, 69, 82. Esta última situação estimula os pacientes a submeterem-se ao tratamento, pela não necessidade de internação hospitalar.

No entanto, esta opção restringe-se àqueles indivíduos cujo defeito ósseo não atinge grandes proporções, devido à limitação de quantidade de tecido ósseo capaz de ser removido das regiões de maxila e mandibula. Naqueles em que a região de defeito ósseo é muito ampla, muitas vezes estendendo-se por todo o rebordo, esta indicação não se faz possivel. Outras regiões, necessariamente, precisariam ser abordadas, como o ílio, costela, tíbia, calvária, entre outras 36, 42, 73, 93. A indicação da região doadora adotada no presente trabalho seguiu basicamente este critério, ou seja, a zona doadora foi eleita em função da extensão da reconstrução. Os defeitos alveolares maxilares tratados 
corresponderam às classes IV, V e VI de acordo com a classificação de rebordos edêntulos preconizada por CAWOOD; HOWELL12, em 1988.

O aumento da demanda por este tipo de tratamento e estas possibilidades de reabilitação menos invasivas estimularam o desenvolvimento de vários estudos clínicos e experimentais com o intuito de se comparar o desempenho dos diferentes ossos utilizados como enxerto para reconstruções de rebordo alveolar 6 , 8, 42, 55, 67, 83, 86. Anteriormente, tais estudos eram encontrados com menor freqüência pela utilização de uma maneira quase que constante do ilio, especialmente nos casos a serem reabilitados com implantes osseointegrados. Pelo comportamento muitas vezes imprevisível deste osso no que diz respeito à reabsorção e pelos transtornos advindos de sua utilização, um número cada vez maior de pesquisadores e cirurgiões vem ressaltando o emprego dos enxertos mais corticalizados, provenientes de maneira mais freqüente dos próprios maxilares ou da calvária. Sua origem diferente representou mais um fator como possivel influenciador no comportamento clínico destes enxertos ósseos $6,18,41,42,79,83$, 86,98 . 
Tais pesquisadores empregaram os enxertos de forma variada, em blocos corticais e córtico-medulares, ou em particulas de osso cortical e ou esponjoso81,87. Neste trabalho, utilizaram-se apenas os enxertos em bloco, em técnica veneer, para conseguir-se um ganho em espessura e altura do rebordo, mantidos por meio de fixação rígida com parafusos de titânio63. O uso de osso particulado não possibilitaria a reconstrução de defeitos com a extensão daqueles encontrados nos pacientes participantes e não permitiria sua fixação, importante para estabilidade inicial e revascularização mais precoce ${ }^{69}$.

Da mesma forma, encontraram-se diferentes condutas quanto ao momento de colocação dos implantes, independentemente da zona doadora e do tipo de enxerto utilizado $1,18,26,39,40,46,55,56,71,88,94$. Técnicas que preconizam a instalação imediata dos implantes evitam que o paciente seja submetido a dois procedimentos cirúrgicos, porém, os resultados variam com relação à sobrevivência dos mesmos.

TRIPLETT \& SCHOW 88 (1996), NEYT et al.59 (1997), SANT'ANA73 (1997), LEKHOLM et al.46 (1999), demonstraram índices de sucesso mais elevados nos procedimentos baseados em dois tempos cirúrgicos. Salientaram fatores como a 
imprevisibilidade do processo de reabsorção que se estabelece em áreas enxertadas, e a maior possibilidade de perda de fixações, como decisivos na opção pela técnica ${ }^{1,71}$.

Apesar do grande número de variáveis que podem influenciar os resultados destes tratamentos, que vão desde as condições locais onde os procedimentos de reabilitação vão ser desempenhados, passando pelas condições sistêmicas do indivíduo, planejamento do caso, experiência do cirurgião, técnica utilizada, até a instalação e o tipo de próteses $7,11,17,21,32,64,80$, 84, 95, se faz nítida a tendência de adoção de dois tempos cirúrgicos como tratamento de eleição para rebordos atróficos.

Mesmo com relação a este tratamento, ainda se discute o período necessário para reparo da região entre os dois tempos cirúrgicos. Na tabela 7 pode-se verificar esta divergência de opiniões entre os autores, com utilização de períodos de reparo que variaram de 3 a 18 meses $1,18,26,39,40,46,55,56,71,88,94$.

Ao que parece, tais opções são norteadas por impressões e experiências clínicas dos autores, ou por publicações de resultados obtidos em modelos experimentais empregando-se animais em condições nem sempre similares. 
A média de tempo observada nestes estudos para a instalação dos implantes é de quatro meses, independentemente do tipo de enxerto utilizado. Ao analisar os trabalhos que demostram as diferenças de revascularização entre os diversos ossos empregados para reconstrução e áreas doadoras, há de se questionar se haveria diferença também quanto ao tempo necessário para reparo antes da colocação dos implantes.

Sendo o ílio e a mandíbula as regiões mais largamente empregadas, e levando-se em consideração a necessidade de identificação da real condição de reparo destes enxertos e suas singularidades, preconizou-se este estudo baseado em análise microscópica de espécimes obtidos de biópsias realizadas em pacientes submetidos a este tipo de tratamento.

Nestes estudo comparativo, avaliaram-se apenas estes dois tipos de enxerto, mento e crista iliaca, num tipo específico de reconstrução alveolar em uma única área receptora, a maxila, no período pós colocação de enxerto de quatro meses. Desta forma, os dados obtidos neste experimento relacionaram-se somente a esta condição clínica. Talvez em outros tipos de técnicas, os resultados apresentados pudessem divergir drasticamente. 
Tabela 7 - Períodos de espera para incorporação dos enxertos ósseos autógenos preconizados por diferentes autores para a instalação dos implantes osseointegrados

\begin{tabular}{|c|c|c|c|}
\hline AUTORES & $\begin{array}{c}\text { ÁREA } \\
\text { DOADORA }\end{array}$ & $\begin{array}{c}\text { ÁREA } \\
\text { RECEPTORA }\end{array}$ & PERÍODOS \\
\hline KELLER, et al. (1987) & Crista ilíaca & Maxila & 6 a 18 meses \\
\hline WIDMARK, et al. (1988) & Crista ilíaca & Maxila & 3 a 4 meses \\
\hline SAILER (1989) & Osso autógeno & Seio maxilar & 4 meses \\
\hline MISCH, et al. (1992) & Mento & Maxila & 4 a 6 meses \\
\hline KELLER, TOLMAN (1992) & Crista ilíaca & Mandíbula & 4 a 6 meses \\
\hline DONOVAN, et al. (1994) & Calvária & Maxila & 6 a 8 meses \\
\hline MISCH; MISCH (1995) & Mento & Maxila & 4 a 6 meses \\
\hline TRIPLETT; SCHOW (1996) & $\begin{array}{c}\text { Crista ilíaca e } \\
\text { mandíbula }\end{array}$ & Maxila / mandíbula & 6 a 9 meses \\
\hline NEYT, et al. (1997) & Crista ilíaca & Maxila & 4 meses \\
\hline MISCH (1997) & Mento e ramo & Maxila & 4 a 6 meses \\
\hline GARG (1998) & Mento & Maxila & 6 a 8 meses \\
\hline KELLER; TOLMAN; EKERT (1999) & Crista ilíaca & Maxila & 4 a 6 meses \\
\hline LEKHOLM, et al. (1999) & $\begin{array}{l}\text { Crista ilíaca e } \\
\text { mandíbula }\end{array}$ & Maxila & 5 a 6 meses \\
\hline
\end{tabular}

Todos os pacientes que participaram do presente trabalho passaram por detalhado exame físico e minuciosa anamnese, além de realizarem exames laboratoriais de rotina. Aqueles submetidos à anestesia geral foram, também, previamente entrevistados pelo médico anestesiologista. Em nenhum deles 
observaram-se alterações físicas ou sistêmicas que contraindicassem ou interferissem com o procedimento, apesar da variação de idades existente.

No momento cirúrgico, atenção foi dada para minimizar o trauma causado pela remoção do osso doador, utilizando-se instrumentais próprios para este objetivo, sob constante refrigeração, sempre que necessária 61. Como verificado por ALBREKTSSON 4 , em 1980, os enxertos minimamente traumatizados revascularizam mais precocemente, favorecendo a osteogênese e o processo de remodelação óssea. Este mesmo estudo revelou atividade enzimática das células ósseas, indicativo de sua viabilidade metabólica. Daí, a importância da variável operador na observação dos resultados e a justificativa da descrição do procedimento empregado neste estudo.

Removidos, os fragmentos ósseos eram imediatamente imersos em solução salina a $0,9 \%$ ou solução de Ringer lactato de sódio, comprovadamente os melhores meios para o armazenamento deste tecido 85.

No período pós-operatório, todos os pacientes receberam terapêutica à base de antibióticos e analgésicos. Aos submetidos 
à anestesia geral, acrescentou-se o uso de antiinflamatórios não esteróides. Esta terapêutica visava o controle dos efeitos indesejáveis da inflamação inicial, além de infecções locais que pudessem comprometer o resultado do tratamento.

Decorridos quatro meses da fixação dos enxertos, no momento da colocação dos implantes, procedeu-se a escolha da área onde as biópsias foram realizadas de forma que não houvesse interferência na instalação dos mesmos. Nenhum dano ou prejuizo ao tratamento foi constatado em decorrência de tal procedimento, comprovados pelas avaliações clínicas e radiográficas de controle. Incluiu-se neste estudo apenas aqueles pacientes em que foi possível a realização da biópsia, ou seja, em reconstruções maiores, uma vez que nos casos menores a remoção do fragmento poderia comprometer a condição óssea do local de instalação dos implantes.

Nesta pesquisa, buscou-se à luz da microscopia óptica, a identificação e caracterização da qualidade óssea existente no período de quatro meses após os procedimentos de enxertia e verificar a existência de diferenças em relação ao reparo de duas diferentes zonas doadoras de enxerto, mento e crista do ílio. Quando se refere ao termo “qualidade óssea” deve-se inferir sua 
aplicação direta. LEKHOLM; ZARB ${ }^{45}$, em 1988, classificaram os rebordos maxilares quanto à sua qualidade, na razão direta da corticalização apresentada. Relacionaram prognósticos mais favoráveis a casos de grande corticalização e fracassos a rebordos com predominância de osso esponjoso com rarefação trabecular. Desta forma, a terminologia qualidade óssea será citada neste trabalho, não relacionando-se aos constituintes celulares, bioquímicos e estruturais do osso, mas à maior ou menor proporção de área de matriz calcificada.

Pela análise feita sob microscopia óptica, os padrões de reabsorção e neoformação óssea nas áreas correspondentes aos enxertos, nos dois grupos, foram semelhantes, com discretas áreas de reabsorção e regiões representativas de neoformação óssea, identificadas pela presença de nítidas linhas de reversão, apesar de predominar a manutenção de uma cortical pouco mais espessa nos enxertos de mento. As áreas irregulares e carcomidas indicativas de reabsorção óssea puderam ser facilmente identificadas. Porém, a presença de células multinucleadas não foi uma constante.

As linhas basofílicas de reversão irregulares localizadas em regiões de tecido ósseo primário, ricamente celularizado e 
desorganizado, sugeriam que o tecido ósseo presente mostrava-se em fase de neoformação, aparecendo de maneira freqüente em todos os espécimes.

Nas regiões mais profundas das biópsias dos enxertos da crista iliaca, correspondentes ao osso receptor, pôde-se verificar trabéculas mais finas, delgadas e em menor número, quando comparadas aos enxertos de mento. Pode-se atribuir esta condição ao fato de que as reconstruções onde se buscou o ílio como osso doador foram feitas em áreas de defeitos maiores. Uma tendência haveria, então, para que as regiões da maxila a serem reconstruídas nestas condições, apresentassem além de quantidade, também qualidade óssea inferior.

Trabéculas ósseas não viáveis foram visualizadas, em ambos os grupos, justapostas a trabéculas recém-formadas, cuja camada osteoblástica apresentava-se mais evidente, denunciando a neoformação óssea. Revestindo as trabéculas tinha-se a presença de camada de endósteo atrófica, constituída por apenas uma camada de células. Por vezes, apresentava-se mais evidente, com células blásticas mais volumosas relacionadas a regiões de neoformação. 
Considerou-se como viáveis, nesta descrição, as trabéculas ósseas cujas lacunas estivessem preenchidas por osteócitos. Não foi utilizado neste trabalho, qualquer tipo de análise histoquímica, considerado método seguro para a avaliação da viabilidade destas células, pela identificação da produção de enzimas diaforases, de origem estritamente intracelulares, produzidas apenas por células metabolicamente ativas ${ }^{3}$. Resguardadas estas limitações do estudo, pôde-se observar nos espécimes obtidos de áreas reconstruídas com crista ilíaca, maior quantidade de trabéculas ósseas não viáveis. Tal fato, denotaria uma maior lentidão no processo de revascularização e remodelação óssea.

Estudo semelhante foi desenvolvido por SHIROTA et al.81, em 1996, onde compararam os padrões de reparação de enxertos ósseos em bloco e particulados utilizados em reconstruções mandibulares, provenientes de uma única área doadora, a crista ilíaca. Após 12 meses do procedimento, pela análise dos espécimes removidos dos individuos que receberam os enxertos ósseos em bloco, os autores também observaram a presença de tecido desvitalizado contendo lacunas sem osteócitos, com formação de novo osso por sobre suas trabéculas. Poucas regiões de reabsorção foram visualizadas. A medula óssea encontrava-se 
frouxamente colagenizada e rica em vasos sangüíneos, resultados bastante semelhantes aos encontrados no presente trabalho em biópsias realizadas aos quatro meses da reconstrução com blocos de crista ilíaca aplicados sobre a maxila.

No trabalho deste autor, no entanto, é enfatizada a influência do tamanho do enxerto sobre a sua posterior remodelação. Enxertos maiores acarretaram maior dificuldade para a reorganização do tecido, necessitando mais tempo para sua completa substituição por tecido ósseo neoformado. Tal fato poderia explicar as diferenças encontradas entre as reconstruções de ilíaco e mento aqui analisadas.

SHIROTA et al., ainda, consideraram estas características satisfatórias em relação à incorporação dos enxertos. Comparativamente, no período de quatro meses, condições semelhantes de reparo foram verificadas, principalmente se observadas as regiões de ilíaco. Se tais condições ainda não são ideais, ao menos observam-se áreas com boa incorporação do enxerto. Surge destas observações o questionamento da indicação de se aguardar tempo tão prolongado para a colocação dos implantes, podendo-se inferir que o período de quatro meses seria suficiente para a realização do segundo tempo cirúrgico, 
independente do tipo de enxerto empregado. Esta afirmação encontra subsídio nas observações clínicas realizadas no presente trabalho, onde se verificou incorporação total dos enxertos, compatível com a inserção dos implantes osseointegrados mesmo sem a utilização do tapping, procedimento que gera estresse na região. Esta constatação clínica vem ao encontro dos achados microscópicos, pois torna-se indistinguivel a interface entre leito receptor e enxerto, com boa parte do osso apresentando-se em processo de remodelação. Apesar do momentâneo sucesso clínico destes casos e da tendência a se estabelecer este período como suficiente para a realização do segundo tempo cirúrgico, ainda persiste o questionamento: qual seria o momento mais oportuno para a colocação dos implantes do ponto de vista biológico da osseointegração, principalmente se observarmos as diferenças de resposta entre o íleo e o mento? Deve-se lembrar que, mesmo em áreas não enxertadas, o próprio trauma cirúrgico da confecção do alvéolo gera áreas ósseas não viáveis que irão sofrer todos estes fenômenos aqui verificados durante o período de osseointegração64. Porém, seria este o momento mais adequado para esta região, em processo de remodelação interagir com o titânio? Assim, discussões quanto à influência de fatores como a natureza e origem dos enxertos, neste momento, têm pouca relevância. 
Trabalhos como os de ZINS \& WHITAKER98 (1983) e KUSIAK; ZINS \& WHITAKER ${ }^{41}$ (1985); ALBERIUS; DAHLIN \& LINDE2 (1992) defendem esta distinção e promovem os enxertos intramembranosos, demonstrando que estes são mais rapidamente vascularizados quando comparados com os endocondrais. Apesar das densas superfícies corticais características dos enxertos intramembranosos, elas parecem não se comportar como uma barreira física à penetração dos vasos locais 41,56 , como revelado no presente estudo pela intensa remodelação óssea presente nas regiões corticalizadas dos enxertos de mento.

Outros autores apresentam opiniões contrárias a estas distinções estabelecidas, preferindo apreciar os fenômenos de revascularização e remodelação do tecido ósseo independente de sua origem, considerando que o comportamento apresentado pela maioria dos enxertos membranosos deva-se à sua arquitetura 6 , $13,16,27,29,83$.

Coerentemente, os trabalhos que se destinam ao estudo da biologia e fisiologia óssea não apontam a origem embriológica como fator modificador de sua composição bioquímica ou 
arquitetura 20, 37, 70. Morfologicamente, o tecido ósseo maduro constitui-se de dois tipos, cortical e esponjoso, formados em resposta às exigências de cada região do corpo. O processo de remodelação ocorre de maneira semelhante em um e em outro, observando-se a mesma população celular e a liberação dos mesmos mediadores, que podem estar mais ou menos presentes, dependendo da quantidade de matriz mineralizada e área de contato com a medula óssea, variando a velocidade do turnover. Desta maneira, pode-se dizer que o processo de reparo dos ossos mais densos, como as corticais, acontece de forma muito mais lenta do que no osso esponjoso. Adicionalmente, a necessidade de liberação de íons cálcio para o sangue é suprida, principalmente, a partir dos ossos esponjosos, pela maior interface que existe entre as trabéculas que os compõem e a medula.

Tal observação encontra fundamento nos resultados aqui apresentados. Em nenhum momento verificou-se qualquer diferença entre as estruturas ósseas estudadas quanto aos seus constituintes celulares e estruturais. Como discutido anteriormente, as diferenças de reparo podem estar associadas às características das reconstruções. É notório que a arquitetura óssea da mandíbula se assemelha à porção do rebordo maxilar, favorecendo este processo de remodelação. Há que se considerar, 
assim, a destinação original destes enxertos que vão sofrer processo adaptativo maior ou menor em relação à zona receptora.

Uma outra análise foi realizada procurando determinar a área de matriz mineralizada presente nos rebordos reconstruídos e correlacionando os resultados com a caracterização da qualidade óssea. Como já discutido, empregou-se o termo "qualidade" para designar ossos com grande porção trabecular e cortical. Quanto maior a densidade, pode-se pressupor melhor condição para implantação.

Para tanto, selecionou-se o corte de maior diâmetro dos espécimes, dividindo-o em três partes proporcionais. Durante a coleta do material, cuidado foi observado no sentido de identificar a porção do cilindro ósseo que correspondia a porção mais superficial e a que correspondia à porção mais profunda, representativas, respectivamente, da zona mais cortical do enxerto e rebordo alveolar, ou sua interface com o bloco ósseo justaposto.

Esta divisão do espécime se deu com o intuito de procurar diferença de qualidade óssea entre estas regiões, e de avaliar se realmente o procedimento de enxertia proporcionou uma melhoria 
nas condições locais de implantação. O terço médio foi eleito pela sua importância clínica, uma vez que justamente nesta área o implante osseointegrado é instalado e, clinicamente se nota diferença entre a qualidade do osso disponível, dependendo da zona doadora.

A escolha do segmento a ser analisado em cada porção do espécime se deu com auxilio de um template retangular projetado sobre a imagem da lâmina. A dimensão deste template acompanhou a máxima proporção possivel para o espécime de menor volume, ou seja, procurou-se aproveitar ao máximo o material disponível para análise. É evidente que em reconstruções maiores, principalmente as que empregaram crista iliaca, as áreas medidas corresponderam a apenas uma parte da amostra, embora, claramente representativa, como verificado na análise exploratória dos resultados.

Os resultados encontrados destas medidas, mostraram-se bastante homogêneos, permitindo as inferências estatísticas com bastante propriedade.

Como primeiro comentário há de se destacar a significativa superioridade do mento sobre o ilíaco quanto à quantidade total 
de matriz mineralizada. MISCH et al.57 (1992), MISCH; MISCH 56 (1995) e GARG et al.26 (1998) enfatizam em seus trabalhos a qualidade do mento quando utilizado para reconstruções alveolares. Apregoam, inclusive, que este proporciona melhor condição para estabilidade inicial dos implantes, além da sua precoce incorporação ao leito receptor. Tais relatos clínicos encontram, neste estudo, subsídios histológicos. Mesmo durante a condução dos casos, no momento da inserção das fixações, estas diferenças foram nitidas, ou seja, nos rebordos aumentados com mento, houve uma exigência de torque maior para a finalização do rosqueamento dos implantes. A partir desta observação foi feita, grosseiramente, a classificação dos rebordos neste trabalho, prevalecendo tipo II para os casos de mento e II ou III para os de ilíaco.

Há que se considerar que a quantidade de aumento obtida com enxertos de mento foi menor, fator limitante de sua indicação clínica em casos mais complexos. Da mesma forma, casos de reconstrução parcial, onde se emprega uma quantidade menor de ilíaco, resultados melhores também são obtidos. A partir disto, infere-se que o fator realmente influenciador nestes procedimentos é a qualidade óssea original da área doadora, especificamente seu constituinte cortical. Se reconstruções 
menores são requeridas, pode-se empregar porções corticais do ílio minimizando estas diferenças aqui encontradas. Com mesmo raciocínio, em grande reconstruções, o risco proporcionalmente é maior, pois, como dicutido na primeira parte deste capítulo, maior a dificuldade para reparo da zona enxertada e maior a demanda óssea, incluindo segmento de osso esponjoso de qualidade inferior para a finalidade de osseointegração.

Estas diferenças de densidade óssea, como bem definidas por MISCH55 (1997), mantiveram-se proporcionais para todas as regiões estudadas, denotando que não somente a medular do íleo possui densidade inferior mas também sua porção cortical. É interessante analisar os resultados encontrados nas regiões C, correspondentes ao rebordo alveolar, onde as diferenças foram menos marcantes. A tendência a uma maior homogeneidade nesta região deve ser atribuída à correlação que guarda com os tecidos receptores, que não diferem por demais entre os pacientes. Nos casos reabilitados com ílio, a densidade óssea foi menor, talvez, caracterizando rebordos com atrofia mais severa e, conseqüentemente, com osso de qualidade inferior. Nestas biópsias, ainda, obteve-se tecido representativo da interface rebordo/enxerto, onde as tendências anteriormente verificadas novamente prevaleceram. 
A representatividade clínica destes resultados foca-se no momento de escolha da zona doadora dos enxertos empregados para reconstruções alveolares. É importante interagir com o paciente quando da opção pelo tratamento uma vez que inúmeras variáveis participam do prognóstico. É evidente que o mento propicia melhor condição local para a osseointegração, porém, possui limitações quanto à área a ser reabilitada. Em casos parciais, por exemplo, o mento pode oferecer volume ósseo suficiente para a inserção de implantes, embora não o suficiente para a recomposição estética do defeito. Nesta situação, também a qualidade óssea deve ser discutida junto ao paciente, representando mais uma opção para o tratamento. E, quando da opção por resconstruções com íleo, atenção especial deve ser dada no momento da implantação para favorecer a estabilidade inicial das fixações, pelo seu posicionamento, buscando ancoragem cortical e mesmo empregando implantes com formato que favoreça estas condições.

Como bem demonstrado por NYSTROM et al.60(1995) os enxertos de osso iliaco mostram-se mais instáveis quanto à manutenção de suas dimensões, principalmente nos primeiros três meses após a reconstrução. Mesmo neste estudo, também se 
verificou maior tendência a reabsorção dos enxertos de crista, constituindo-se mais um dado para justificar a eleição pelo tratamento em dois tempos cirúrgicos onde, decorridos quatros meses, teria-se uma visão mais real do volume ósseo obtido. Nos casos de enxerto de mento, como corroboram MISCH et al.57(1992), MISCH55 (1997) e GARG et al.26 (1998), este fenômenos resorptivos mostraram-se, aparentemente, menos severos. Tais condições, aqui alicerçadas por estudo microscópico, confirmam as observações clínicas feitas por $\operatorname{MARX}^{49}$ (1994) e MARX; GARG50 (1998).

De qualquer forma, ao avaliar-se a Figura 25, vislumbra-se o dado mais representativo deste estudo: independentemente da área doadora, obteve-se uma melhoria das condições locais com os procedimentos de enxertos ósseos.

CLELLAND et al.14(1991) demonstraram que a incidência maior de estresse resultante de forças oclusais sobre próteses sobre implantes, se dá na porção de crista óssea alveolar. Exatamente por isso, MISCH; $\operatorname{MISCH}^{56}$ (1995) chamam a atenção para que nesta região osso denso esteja disponível, oferecendo uma interface mais favorável a distribuição destes esforços para o componente alveolar. A melhoria das condições do rebordo com 
procedimentos reconstrutivos vem ao encontro destes argumentos, na busca de prognósticos mais favoráveis para as reabilitações com implantes osseointegrados.

A reconstrução de rebordos atróficos visa, num primeiro momento, a obtenção de volume ósseo para a colocação de implantes. Num segundo momento, a melhoria da qualidade do tecido uma vez que sobre estes implantes incidirão forças, nem sempre favoráveis. Por estudo demonstrou-se que ambos os procedimentos reconstrutivos atendem a estas necessidades, constituindo-se uma realidade dentro do arsenal terapêtico do cirurgião-dentista.

Muito se discutiu sobre outros fatores, intrínsecos à técnica e ao local de obtenção dos enxertos, que devem ser considerados buscando-se prognósticos mais favoráveis, previsiveis e resultados otimizados.

Porém, com toda a cautela que procedimentos e técnicas cirúrgicas devem merecer, há de se ressaltar que tais tratamentos constituem opções relativamente novas. Muito se tem a pesquisar e a garantia dos resultados aqui encontrados só se confirmará com o seguimento clínico destes casos. O que 
realmente importa, em todo este contexto, é a satisfação do ser humano que se submete a toda esta agressão com a finalidade de reaver funções, estética e qualidade de vida. 


\section{CONCLUSÕES}

A partir da análise dos resultados obtidos e respeitando-se as limitações do modelo experimental, pode-se concluir que:

1. No período de quatro meses após a reconstrução alveolar com enxertos provenientes de crista ilíaca e mento, ambos apresentaram-se em franco processo de remodelação revelado pelo intenso processo de osteogênese observado e intima incorporação destes às áreas receptoras. Desta forma, considera-se este período como suficiente para a instalação de implantes osseointegrados.

2. Ambos os enxertos proporcionaram melhoria de qualidade óssea no local da implantação; a despeito do volume da reconstrução, os enxertos de mento proporcionaram qualidade óssea superior em todas as regiões estudadas. 
ANEXOS 


\section{COMISSÃO DE ÉTICA EM PESQUISA \\ UNIVERSIDADE DO SAGRADO CORAÇÃO \\ Rua Irmã Arminda 10-50 Bauru - S.P.}

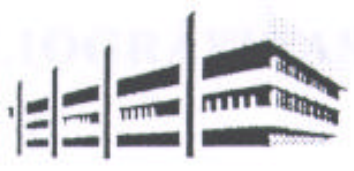

\section{PARECER TÉCNICO}

A pesquisa possui justificativa, objetivos e procedimentos que serão utilizados; desconfortos, efeitos colaterais e possiveis riscos, além dos benefícios esperados; métodos alternativos existentes e evidências do que está sendo pesquisado é realmente para melhoria dos recursos já existentes. Ressalta de forma minuciosa o acompanhamento e assistência dos pacientes bem como o nome e telefone de contato dos pesquisadores responsáveis, a garantia de esclarecimento, antes e durante a pesquisa, sobre a metodologia utilizada, clareza sobre a liberdade do sujeito se recusar a participar ou retirar seu consentimento, em qualquer fase da pesquisa, sem penalização alguma e sem prejuizo ao seu cuidado; garantia de sigilo e privacidade dos voluntários da pesquisa e formas de ressarcimento de despezas decorrentes da participação no estudo.

Em se tratando de pesquisa em seres humanos, o projeto se adequa as normativas bioéticas vigentes e não se vê obstáculo para o desenvolvimento formal desta aplicação metodológica.

APROVADO

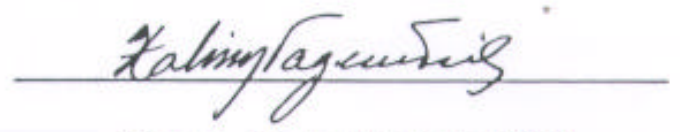

Bauru, 24 de Abril de 1999

Comissão de Ética em Pesquisa 


\section{REFERÊNCIAS BIBLIOGRÁFICAS *}

1. ADELL, R. et al. Reconstruction of severely resorbed edentulous maxillae using osseointegrated fixtures in immediate autogenous bone grafts. Int. J. oral Maxillofac. Surg., v.5, n.3, p.233-46, 1990.

2. ALBERIUS, P.; DAHLIN, C.; LINDE, A. Role of osteopromotion in experimental bone grafting to the skull: a study in adult rats using a membrane technique. J. oral Maxillofac. Surg., v.50, n.8, p.829-34, Aug. 1992.

3. ALBREKTSSON, T. Repair of bone grafts. A vital microscopic and histological investigation in the rabbit. Scand. J. plast. reconstr. Surg., v.14, n.1, p.1-12, 1980.

4. ALBREKTSSON, T. The healing of autologous bone grafts after varying degrees of surgical trauma. J. Bone Joint Surg., v.62-B, n.3, p.403-10, Aug. 1980.

5. ALBREKTSSON, T. Ischaemia and bone grafts. Scand. J. plast. reconstr. Surg., v.19, p.21-4, 1982. Supplement.

6. ALONSO, N. et al. Cranial versus iliac onlay bones grafts in the facial skeleton: a macroscopic and histomorphometric study. J. craniofac. Surg., v.6, n.2, p.113-8, Mar. 1995.

7. BLOMQVIST, J.E. et al. Factors in implant integration failure after bone grafting. An osteometric and endocrinologic matched analysis. Int. J. oral Maxillofac. Surg., v.25, n.1, p.63-8, Feb. 1996.

8. BORSTLAP, W.A. et al. Early secondary bone grafting of alveolar cleft defects: a comparison between chin and rib grafts. J. cranio maxillofac. Surg., v.18, n.5, p.201-5, 1990.

\footnotetext{
*Normas recomendadas para uso no âmbito da Universidade de São Paulo, com base no documento "Referências bibliográficas: exemplos", emanado do Conselho Supervisor do Sistema Integrado de Bibliotecas da USP, em reunião de 20 de setembro de 1990.
} 
9. BRANEMARK, P.I. et al. Anatomy of osseointegration and the transfer of load. In: FONSECA, R.J.; DAVIS, W.H. Reconstructive preprosthetic oral and maxillofacial surgery. 2.ed. Philadelphia, W.B. Saunders, 1995. Cap.8, p.165-223.

10. BREINE, U.; BRANEMARK, P-I. Reconstruction of alveolar jaw bone. Scand. J. plast. reconstr. Surg., v.14, n.1, p.14-48, 1980.

11. BRYANT, S.R. The effects of age, jaw site, and bone condition on oral implants outcome. Int. J. Prosthodont., v.11, n.5, p.470-90, Oct. 1998.

12. CAWOOD, J.I.; HOWELL, R.A. A classification of the edentulous jaws. Int. J. oral Maxillofac. Surg., v.17, n.4, p.232-6, 1988.

13. CITARDI, M.J., et al. Nonvascularized autogenous bone grafts for craniofacial skeletal augmentation and replacement. Otolaryngol. Clin. N. Amer., v.27, n.5, p.891-910, Oct. 1994.

14. CLELLAND, N.L., et al. Three-dimensional finite element stress analysis in and around the Screw-Vent implant. Int. J. oral Maxillofac. Implants, v.6, n.4, p.391-8, 1991.

15. DAVIES, J.E. Mechanisms of endosseous integration. Int. J. Prosthodont., v.11, n.5, p.391-401, Sept./Oct. 1998.

16. DeLACURE, M.D. Physiology of bone healing and bone grafts. Otolaryngol. Clin. N. Amer., v.27, n.5, p.859-74, Oct. 1994.

17. DEVLIN, H.; HORNER, K.; LEDGERTON, D. A comparison for maxillary and mandibular bone mineral densities. J. prosth. Dent., v.79, n.3, p.3237, Mar. 1998.

18. DONOVAN, M.G. et al. Maxillary and mandibular reconstruction using calvarial bone grafts and Branemark implants: a preliminary report. $\mathbf{J}$. oral Maxillofac. Surg., v.52, n.6, p.588-94, June 1994.

19. ENGQUIST, B. et al. A retrospective multicenter evaluation of osseointegrated implants supporting overdentures. Int. J. Oral Maxillofac. Surg., v.3, n.2, p.129-34, Mar./Apr. 1988.

20. ERIKSEN, E.F.; AXELROD, D.W.; MELSEN, F. Bone histomorphometry. New York, Raven Press, 1994. 
21. ESPOSITO, M. et al. Biological factors contributing to failures in osseointegrated oral implants (II). Etiopathogenesis. Europ. J. oral Science, v.106, n. 3, p.721-64, June 1998.

22. FEIFEL, H.; RIEDIGER, D.; WEISKE, R. Measurement of mandibular bone density after iliac crest grafting. Int. J. oral Maxillofac. Surg., v.23, n.2, p.104-9, 1994.

23. FERRI, J. et al. Advantages and limitations of the fibula free flap in mandibular reconstruction. J. oral Maxillofac. Surg., v.55, n.5, p.4408, May 1997.

24. FRIBERG, B.; TORSTEN, J.; LEKHOLM, U. Early failures in 4,641 consecutively placed Branemark dental implants: a study from stage 1 surgery to the connection of completed prostheses. Int. J. Oral Maxillofac. Surg., v.6, n.2, p.142-6, Mar./Apr. 1991.

25. GARETTO, L.P. et al. Remodeling dynamics of bone supporting rigidly fixed titanium implants: a histomorphometric comparison in four species including humans. Implant Dent., v.4, n.4, p.235-43, 1995.

26. GARG, A. K. et al. Autogenous mandibular bone grafts in the treatment of the resorbed maxillary anterior alveolar ridge: rationale and approach. Implant Dent., v.7, n.3, p.169-76, 1998.

27. GLOWACKI, J. Craniofacial onlay bone grafting: a prospective evaluation of graft morphology, orientation and embryologic origin /Discussion/. Plast. reconstr. Surg., v.85, n.1, p.15, Jan. 1990.

28. GRUBER, H.; SOLAR, P.; ULM, C. Maxillo-mandibular anatomy and resorption pattern during atrophy. In: WATZEK, G. Endosseous implants: scientific and clinical aspects. Chicago, Quintessence books, 1996. Cap. 2, p.29-62.

29. HARDESTY, R.A.; MARSH, J.L. Craniofacial onlay bone grafting: a prospective evaluation of graft morphology, orientation, and embryonic origin. Plast. reconstr. Surg., v.85, n.1, p.5-14, Jan. 1990.

30. HOAGLiN, D.C.; MOSTELLER, F.; TUKEY, J.W. Análise exploratória de dados. Técnicas robustas. Lisboa, Edições Salamandra, 1981.

31. HOPPENREIJS, T.J.M.; NIJDAM, E.S.; FREIHOFER, H.P.M. The chin as a donor site in early secondary osteoplasty: a retrospective clinical and 
radiological evaluation. J. cranio maxillofac Surg., v.20, n.3, p.119-24, Apr. 1992.

32. HUTTON, et al. Factors related to success and failure rates at 3-year followup in a multicenter study in overdentures supported by Branemark implants. Int. J. oral Maxillofac. Implants, v.10, n.1, p.33-42, Jan./Feb. 1995.

33. ISAKSSON, S. et al. Early results from reconstruction of severely atrophic (class VI) maxillas by immediate endosseous implants in conjunction with bone grafting and Le Fort I osteotomy. Int. J. oral Maxillofac. Surg., v.22, n.3, p.144-8, June 1993.

34. JAFFIN, R.A.; BERMAN, C.L. The excessive loss of Branemark fixtures in type IV bone: a 5-year analysis. J. Periodont., v.62, n.1, p.2-4, Jan. 1991.

35. JEMT, T.; LEKHOLM, U. Implant treatment in edentulous maxillae: a 5-year follow-up report on patients with different degrees of jaw resorption. Int. J. oral Maxillofac. Surg., v.10, n.3, p.303-11, May/June 1995.

36. JENSEN, J.; SIMONSEN, E.K.; SINDET-PEDERSEN, S. Reconstruction of the severely resorbed maxilla with bone grafting and osseointegrated implants: a preliminary report. J. oral Maxillofac. Surg., v.48, n.1, p.27-32, Jan. 1990.

37. JUNQUEIRA, L.C.; CARNEIRO, J. Histologia básica. 8. ed. Rio de Janeiro, Guanabara Koogan, 1995. Cap. 8, p.108-26.

38. KAWAI, T.; MURAKAMI, S.; HIRANUMA, H. Radiologic appraisal of healing after iliac crest bone grafts. Oral Surg.,v.77, n.6, p.678-83, June 1994.

39. KELLER, E.; TOLMAN, D.; ECKERT, S. Surgical-prosthodontic reconstruction of advanced maxillary bone compromise with autogenous onlay block bone grafts and osseointegrated endosseous implants: a 12year study of 32 consecutive patients. Int. J. oral Maxillofac. Implants, v.14, n.2, p.197-209, Mar./Apr. 1999.

40. KELLER, E. et al. Prosthetic-surgical reconstruction of the severely resorved maxilla with iliac bone grafting and tissue-integrated prostheses. Int. J. oral Maxillofac. Implants, v.2 , n.3, p.155-65, 1987. 
41. KUSIAK, J.F., ZINS, J.E.; WHITAKER, L.A. The early revascularization of membranous bone. Plast. reconstr. Surg., v.76, n.4, p.510-16, Oct. 1985.

42. LA ROSSA, D. et al. A comparison of iliac and cranial bone in secondary grafting of alveolar clefts. Plast. reconstr. Surg., v.96, n.4, p.789-97, Sept. 1995.

43. LAURIE, S.W.S., et al. Donor-site morbidity after harvesting rib and iliac bone. Plast. reconstr. Surg., v.73, n.6, p.933-38, June 1984.

44. LEE, M.B. Bone morphogenetic proteins: background and implications for oral reconstruction. A review. J. clin. Periodont., v.24, n.6, p.355-65, June 1997.

45. LEKHOLM, U.; ZARB, G.A. Patient selection and preparation. In: BRANEMARK, P-I.; ZARB, G.A.; ALBREKTSSON, T. Tissue-integrated prosthesis: osseointegration in clinical dentistry. Chicago, Quintessence books, 1985, Cap. 12, p.199-209.

46. LEKHOLM, U. et al. Oral implants in combination with bone grafts. Int. J. oral Maxillofac. Surg., v.28, n.3, p.181-7, June 1999.

47. LEVIN, L.M. et al. Bone induction and the biology of grafting. In: FONSECA, R.J.; DAVIS, W.H. Reconstructive preprosthetic oral and maxillofacial surgery, 2 ed. Philadelphia, W.B. Saunders, 1995. Cap.3, p. 41-72.

48. LI, K.K.; STEPHENS, W.L.; GLIKLICH, R. Reconstruction of the severely atrophic edentulous maxilla using Le Fort I osteotomy with simultaneous bone graft and implant placement. J. oral Maxillofac. Surg., v.54, n.5, p.542-6, May 1996.

49. MARX, R.E. Clinical application of bone biology to mandibular and maxillary reconstruction. Clin. plast. Surg., v.21, n.3, p.377-92, July 1994.

50. MARX, R.E.; GARG, A.K. Bone structure, metabolism and physiology: its impact on dental implantology. Implant Dent., v.7, n.4, p.267-75, 1998.

51. MARX, R.E.; SNYDER, R.M.; KLINE, S.N. Cellular survival of humam marrow during placement of marrow cancellous bone grafts. J. Oral Surg., v.37, n.10, p.712-8, Oct. 1979. 
52. MASUDA, T. et al. Generalizations regarding the process and phenomenon of osseointegration. Part I. in vivo studies. Int. J. oral Maxillofac. Surg., v.13, n.1, p.17-29, Jan./Feb. 1998.

53. MISCH, C.E. Edentulous alveolar ridge augmentation and restorative grafting. In: Mosby, 1993. Cap. p.422-43.

54. MISCH, C.E. et al. A bone quality-based implant system: a preliminary report of stage I \& stage II. Implant Dent., v.7, n.1, p.35-42, 1998.

55. MISCH, C.M. Comparison of intraoral donor sites for onlay grafting prior to implant placement. Int. J. oral Maxillofac. Implants, v.12, n.6, p. 767 76, Nov./Dec. 1997.

56. MISCH, C.M.; MISCH, C.E. The repair of localized severe ridge defects for implant placement using mandibular bone grafts. Implant Dent., v.4, n.4, p.261-7, 1995.

57. MISCH, C.M. et al. Reconstruction of maxillary alveolar defects with mandibular symphysis grafts for dental implants: a preliminary procedural report. Int. J. oral Maxillofac. Implants, v.7, n.3, p.360-6, 1992.

58. NADE, S.; BURWELL, R.G. Decalcified bone as a substrate for osteogenesis: an appraisal of the interrelation of bone and marrow in combined grafts.

J. Bone Joint Surg., v.59-B, p.189-96, 1977.

59. NEYT, L.F. et al. Reconstruction of the severely resorbed maxilla with a combination of sinus augmentation, onlay bone grafting, and implants. J. oral Maxillofac. Surg., v.55, n.12, p.1397-1401, Dec. 1997.

60. NYSTRÖM, E. et al. Combined use of bone grafts and implants in the severely resorbed maxilla. Int. J. oral Maxillofac. Surg., v.24, n.1 pt1, p.20-5, Feb. 1995.

61. OKAMOTO, T.; YAMAMOTO, M.E.; SONODA, C.K. Processo de reparação óssea após osteotomia com instrumentos rotatórios de alta rotação. Rev. bras. Odont., v.51, n.1, p.21-5, jan./fev. 1994. 
62. PEREIRA, A.C. Influência da gravidez e dos anticoncepcionais na reabsorção radicular e na remodelação óssea, consequiente à movimentação dentária induzida: avaliação microscópica. Bauru, 1995. Dissertação (Mestrado) - Faculdade de odontologia de Bauru, Universidade de São Paulo.

63. PHILLIPS, J.H.; RAHN, B.A. Fixation effects on membranous and endochondral onlay bone graft revascularization and bone deposition. Plast. reconstr. Surg., v.85, n.6, p.891-7, June 1990.

64. PIATTELLI, A.; SCARANO, A.; PIATTELLI, M. Microscopical aspects of failure in osseointegrated dental implants: a report of five cases. Biomaterials, v.17, n.12, p.1235-41, June 1996.

65. PIATTELLI, A. et al. Histologic analysis of the interface of a titanium implant retrieved from a nonvascularized mandibular block graft after a 10month loading period. Int. J. oral Maxillofac. Implants, v.12, n.6, p.840-3, Nov./Dec. 1997.

66. PIMENTEL-GOMES, F. Curso de estatística experimental. 12.ed. São Paulo, Nobel, 1987.

67. PINHOLT, E.M. et al. Revascularization of calvarial, mandibular, tibial and iliac bone grafts in rats. Ann. plast. Surg., v. 33, n. 2, p.193-7, Aug. 1994.

68. RABIE, A.B.M.; LIE KEN JIE, R.K.P. Integration of endochondral bone grafts in the presence of demineralized bone matrix. Int. J. oral Maxillofac. Surg., v.25, n.4, p.311-8, Aug. 1996.

69. RISSOLO, A.R.; BENNETT, J. Bone grafting and its essential role in implant dentistry. Dent. Clin. N. Amer., v.42, n.1, p.91-116, Jan. 1998.

70. ROBERTS, W.E. et al. Bone physiology and metabolism. Amer. J. Anat., v.15, n.10, p.54- 61, Oct. 1987.

71. SAILER, H.F. A new method of inserting endosseous implants in totally atrophic maxillae. J. cranio maxillofac Surg., v.17, n.1, p.299-305, Oct. 1989.

72. SAKOU, T. Bone morphogenetic proteins: from basic studies to clinical approaches. Bone, v.22, n.6, p.591-603, June 1998. 
73. SANT'ANA, E. Sobrevivência a curto prazo de implantes osseointegrados instalados em rebordos alveolares reconstruidos com enxerto autógeno. Bauru, 1997. Tese (Doutorado) - Faculdade de Odontologia de Bauru, Universidade de São Paulo.

74. SCHENK, R.K. et al. Healing pattern of bone regeneration in membraneprotected defects: a histologic study in the canine mandible. Int. J. oral maxillofac. Implants, v.9, n.1, p.13-29, June 1994.

75. SCHENK, R.K. Bone regeneration: biologic basis. In : BUSER, D.; DAHLIN, C.; SCHENK. R.K. Guided bone regeneration in implant dentistry. St. Louis, Quintessence books, 1994. p. 49-100.

76. SCHLIEPHAKE, H.; NEUKAM, F.W.; WICHMANN, M. Survival analysis of endosseous implants in bone grafts used for the treatment of severe alveolar ridge atrophy. J. oral Maxillofac. Surg., v.55, n.11, p.1227-33, Nov. 1997.

77. SCHLIEPHAKE, H. et al. Langzeitergebnisse osteointegrierter Schraubenimplantate in Kombination mit Osteoplastiken. Z. Zahnärztl Implantol., v.13, p.73-8, 1997 apud SENNERBY, L.; ROOS, J. Surgical determinants of clinical success of osseointegrated oral implants: a review of the literature. Int. J. Prosthodont., v.11,n.5, p.408-20, Sept./Oct. 1998.

78. SCHWARTZ, Z . et al. Underlying mechanisms at the bone-surface interface during regeneration. J. Periodont. Res., v.32, n.1, p.166-71, 1997.

79. SCOTT, C.K.; HIGHTOWER, J.A. The matrix of endochondral bone differs from the matrix of intramembranous bone. Calcif. Tiss. Res., v. 49, n. 5, p.349-54, Nov. 1991.

80. SENNERBY, L.; ROOS, J. Surgical determinants of clinical success of osseointegrated oral implants: a review of the literature. Int. $J$. Prosthodont., v.11,n.5, p.408-20, Sept./Oct. 1998.

81. SHIROTA, T. et al. Histologic and microradiologic comparison of block and particulate cancellous bone and marrow grafts in reconstructed mandibles being considered for dental implant placement. J. oral Maxillofac. Surg., v.54, n.1, p.15-20, Jan. 1996. 
82. SINDET-PEDERSEN, S.; ENEMARK, H. Mandibular bone grafts for reconstruction of alveolar clefts. J. oral Maxillofac. Surg., v. 46, n 7, p.533-37, July 1988.

83. SOLHEIM, E. et al. Bone formation in cranial, mandibular, tibial, and iliac bone grafts in rats. J. craniofac. Surg., v.6, n.2, p.139-42, Mar. 1995.

84. STEFLIK, D.E., et al. Dental implants retrieved from humans: a diagnostic light microscopic review of the findings in seven cases of failure. Int. J. oral Maxillofac. Surg., v.6, n.2, p.147-53, Mar./Apr. 1991.

85. STEINER, M.; RAMP, W.K. Short-term storage of freshly harvested bone. J. oral Maxillofac. Surg., v.46, n.10, p.868-71, Oct. 1988.

86. SULLIVAN, W.G.; SZWAJKUN, P.R. Revascularization of cranial versus iliac crest bone grafts in the rat. Plast. reconstr. Surg., v.87, n. 6, p.1105-9, June 1991.

87. TOLMAN, D.E. Reconstructive procedures with endosseous implants in grafted bone: a review of the literature. Int. J. oral Maxillofac. Surg., v.10, n.3, p.275-94, May/June 1995.

88. TRIPLETT, R.G.; SCHOW, S.R. Autologous bone grafts and endosseous implants: complementary techniques. J. oral Maxillofac. Surg., v.54, n.4, p.486-34, Apr. 1996.

89. TRUETA, J. The role of the vessels in osteogenesis. J. Bone Joint Surg., v.45B, n.2, p.402-18, May 1963.

90. TRUHLAR, R.S. et al. Distribution of bone quality in patients receiving endosseous dental implants. J. oral Maxillofac. Surg., v.55, n.12, p.3845, Dec. 1997. Supplement 5.

91. TULER, R.F.; NARY FILHO, H. Avaliação da morbidade da região mentoniana como área doadora para enxertos ósseos autógenos. /Apresentado à 16a Reunião Anual da Sociedade Brasileira de Pesquisa Odontológica, 1999/

92. VASCONCELOS, L.W. et al. O emprego de cirurgias avançadas na viabilização de implantes. In: VANZILLOTA, P.S.; SALGADO, L.P.S. Odontologia integrada: atualização multidisciplinar para o clínico e o especialista. Rio de Janeiro, Pedro Primeiro, 1999. Cap. 1, p. 23-50. 
93. VERHOEVEN, J.W. The combined use of endosteal implants and iliac crest onlay grafts in the severely atrophic mandible: a longitudinal study. Int. J. oral Maxillofac. Surg., v.26, n. 5, p.351-7, Oct. 1997.

94. WIDMARK, G. et al. Rehabilitation of patients with severely resorbed maxillae by means of implants with or without bone grafts. A 1-year follow-up study. Int. J. oral Maxillofac. Implants., v.13, n.4, p.474-82, July/Aug. 1998.

95. WILSON, T.G. et al. Implants placed in immediate extraction sites: a report of histologic and histometric analyses of human biopsies. Int. J. oral Maxillofac. Surg., v.13, n.3, p.333-41, May/June 1998.

96. WOLFORD, L.M.; COOPER, R.L. Alternative donor sites for maxillary bone grafts. J. oral Maxillofac. Surg., v.43, n.6, p.471-2, June 1985.

97. YASZEMSKI, M.J. et al. Evolution of bone trasnplantation: molecular, cellular and tissue strategies to engineer human bone. Biomaterials, v.17, n.2, p.175-85, Jan. 1996.

98. ZINS, J.E.; WHITAKER, L.A. Membranous versus endochondral bone: implications for craniofacial reconstruction. Plast. reconstr.Surg., v.72, n.6, p. 778-85, Dec. 1983. 


\section{ABSTRACT}

\section{Microscopical analysis of reconstructed maxillary alveolar ridges using iliac crest and chin autogenous bone grafts}

The insertion of endosseous implants in atrophic ridges reconstructed with autogenous bone grafts has been extensively used, most of the times using two-stage technique. In this study, bone graft repair and bone quality achieved in maxillary ridges reconstructed using iliac crest and chin bone grafts were analysed under light microscopy. Ten patients who underwent this procedure were observed in this study. After 4 months of the bone graft surgery, at the moment of the implants installation, 5 specimens were obtained from biopsies made in each bone graft group using trephine burs. The specimens underwent routine histotechnical procedure and stained by H.E. and Mallory triple stain. As a result, process of bone turnover was revealed by the areas of intense osteogenesis. From the analysis of mineralized bone tissue surface areas, significant greater values were verified in maxillary ridge regions reconstructed with chin graft. From these results, it was concluded that the period of 4 months was sufficient to the incorporation of the grafts. It was also concluded 
that chin grafts presented better bone quality than iliac crest grafts. 